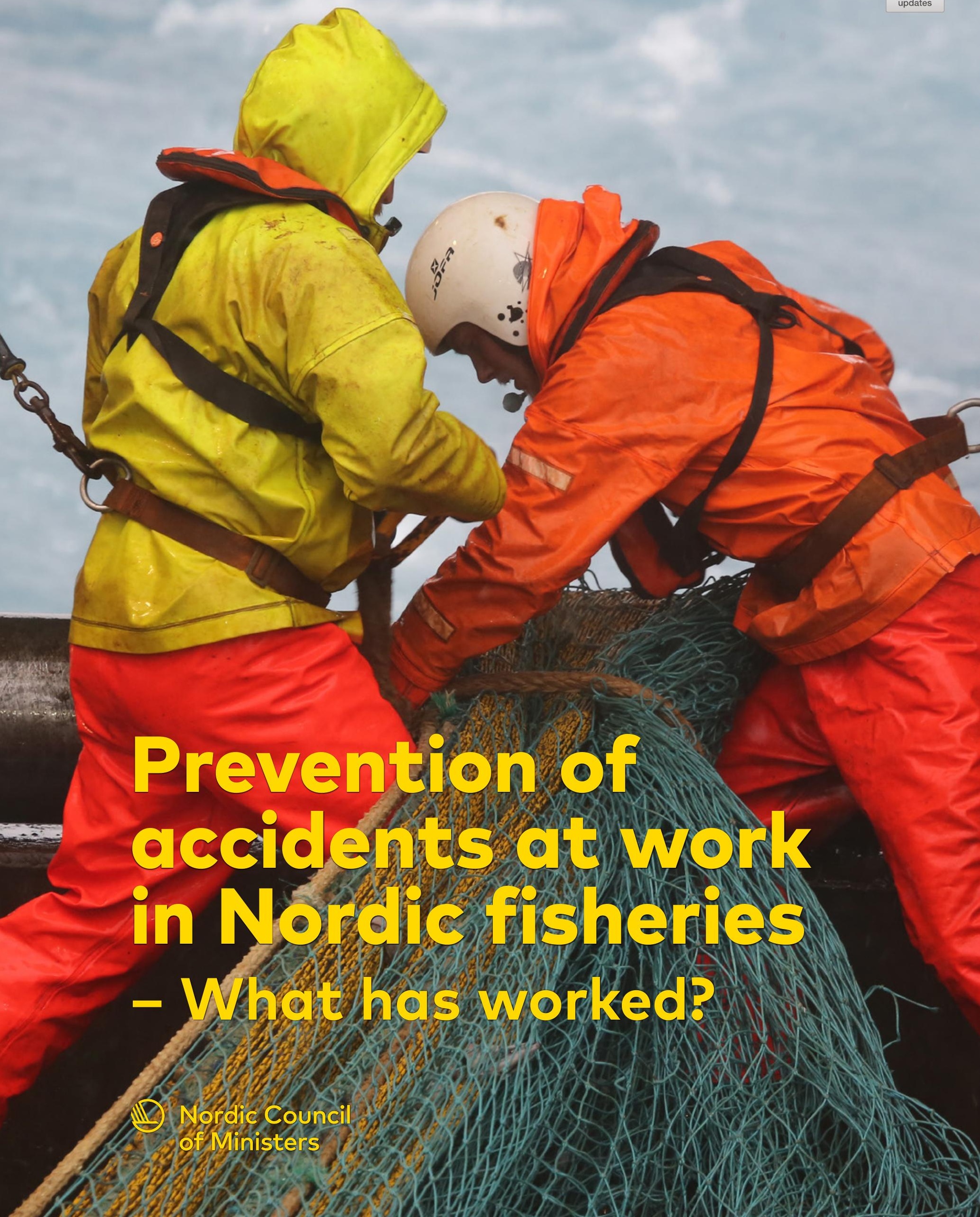




\section{Prevention of accidents at work in Nordic fisheries}

- What has worked?

Edited by: Jørgen Møller Christiansen and Sarah Rettig Hovmand

TemaNord 2017:509 
Prevention of accidents at work in Nordic fisheries

- What has worked?

Edited by: Jørgen Møller Christiansen and Sarah Rettig Hovmand

ISBN 978-92-893-4887-4 (PRINT)

ISBN 978-92-893-4888-1 (PDF)

ISBN 978-92-893-4889-8 (EPUB)

http://dx.doi.org/10.6027/TN2017-509

TemaNord 2017:509

ISSN 0908-6692

Standard: PDF/UA-1

ISO 14289-1

(c) Nordic Council of Ministers 2017

Layout:NMR

Cover photo: Thorgeir Baldurssson

Photos: Thorgeir Baldursson

Printed in Denmark

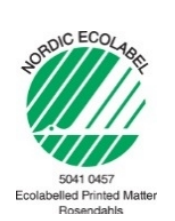

Although the Nordic Council of Ministers funded this publication, the contents do not necessarily reflect its views, policies or recommendations.

\section{Nordic co-operation}

Nordic co-operation is one of the world's most extensive forms of regional collaboration, involving Denmark, Finland, Iceland, Norway, Sweden, the Faroe Islands, Greenland, and Åland.

Nordic co-operation has firm traditions in politics, the economy, and culture. It plays an important role in European and international collaboration, and aims at creating a strong Nordic community in a strong Europe.

Nordic co-operation seeks to safeguard Nordic and regional interests and principles in the global community. Shared Nordic values help the region solidify its position as one of the world's most innovative and competitive. 


\section{Contents}

Introduction

Part 1 .

1. Occupational accidents and safety work in the Nordic fisheries - Developments and preventive measures

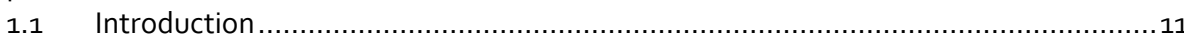

2. Norway: Occupational accidents and safety work in the Norwegian fishery-

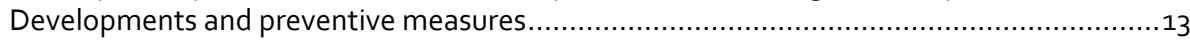

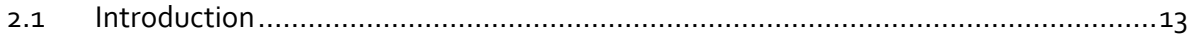

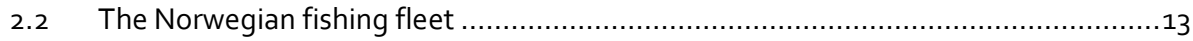

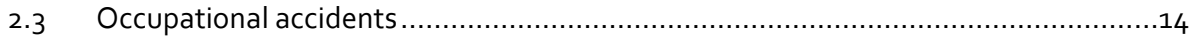

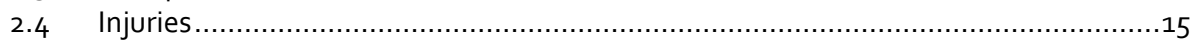

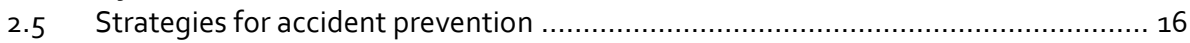

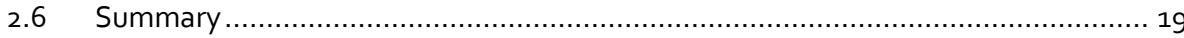

3. Finland: Occupational accidents and safety work in the Finnish fishery - Developments

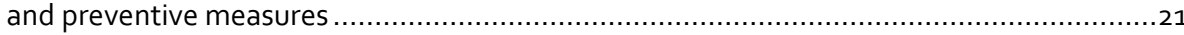

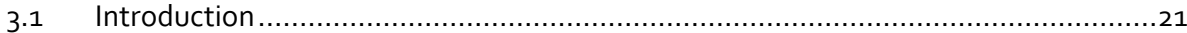

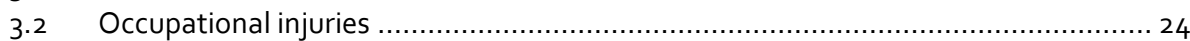

3.3 Measures taken to prevent accidents and injuries ......................................... 28

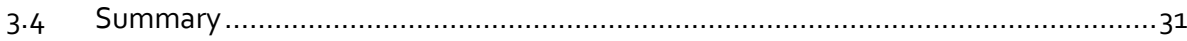

4. The Faroe Islands: Occupational accidents and safety work in the Faroese fishery -

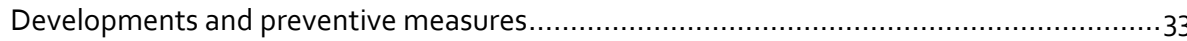

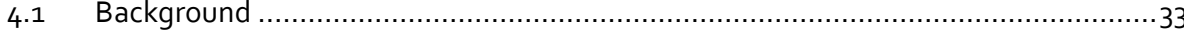

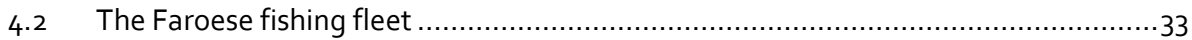

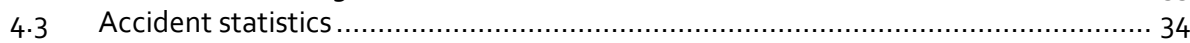

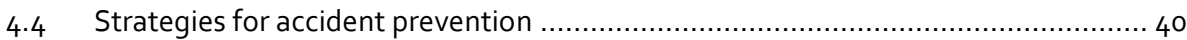

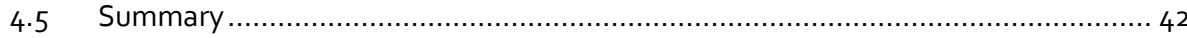

5. Iceland: Occupational accidents and safety work in the Icelandic fishery-Developments

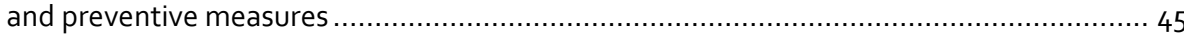

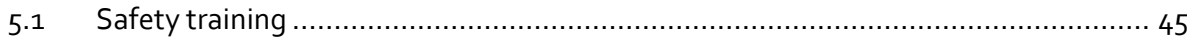

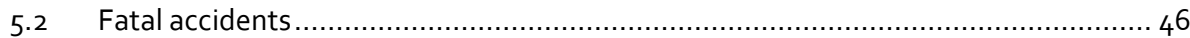

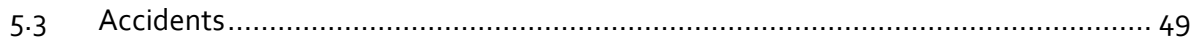

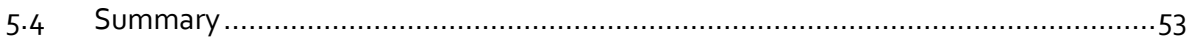

6. Denmark: Occupational accidents and safety work in the Danish fishery-Developments

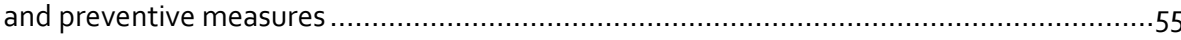

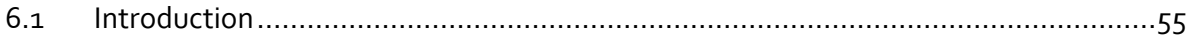

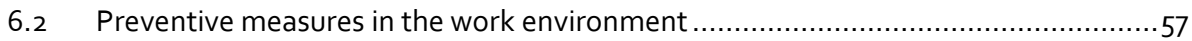

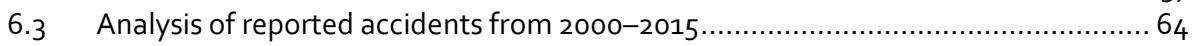

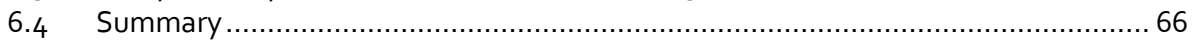


7. Summary - Nordic fishing, the regulation of fisheries and accidents in fishery ................67

7.1 The development in occupational accidents in the Nordic countries .....................68

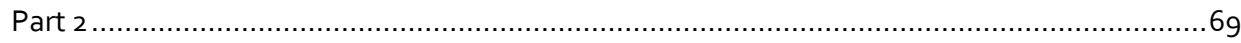

8. Survey, the fishermen's view - Measures taken to prevent accidents in the

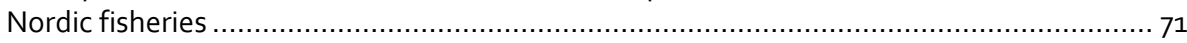

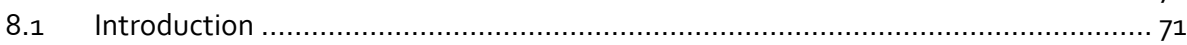

9. Norway: The fishermen's view - Measures taken to prevent accidents in the

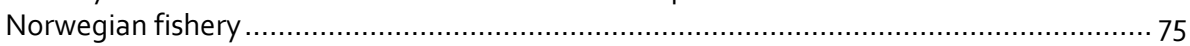

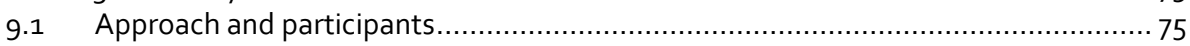

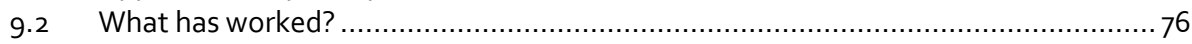

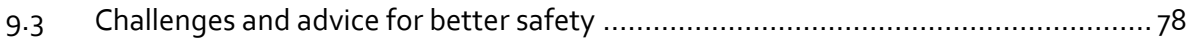

10. Finland: The fishermen's view - Measures taken to prevent accidents in the

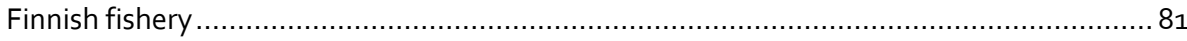

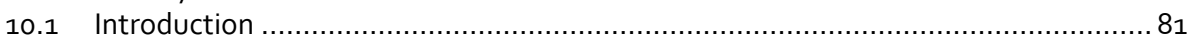

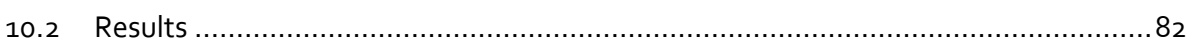

10.3 The greatest challenges for safety prevention in fisheries ….......................... 83

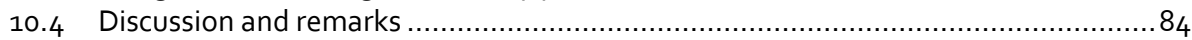

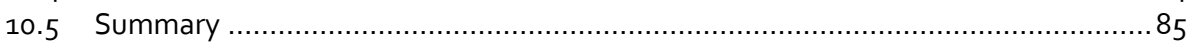

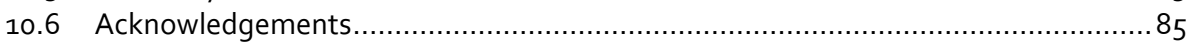

11. The Faroe Islands: The fishermen's view - Measures taken to prevent accidents in the

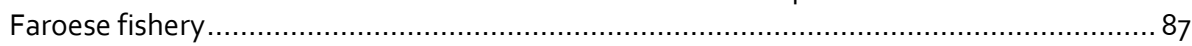

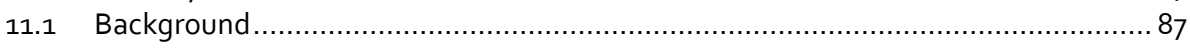

11.2 The Fishermen's view on agents that have been installed for the purpose of

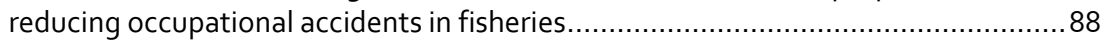

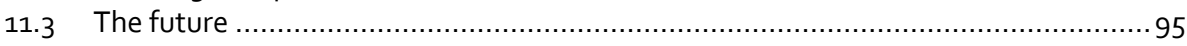

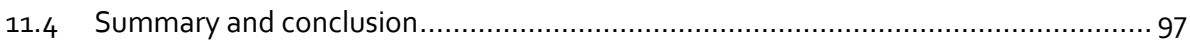

12. Iceland: The fishermen's view - Measures taken to prevent accidents in the

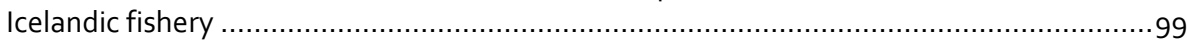

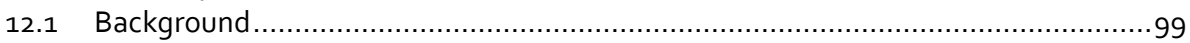

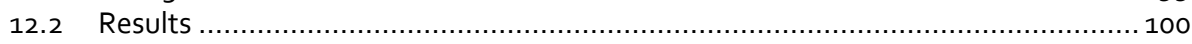

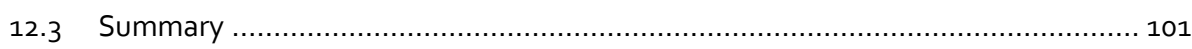

13. Denmark: The fishermen's view - Measures taken to prevent accidents in the

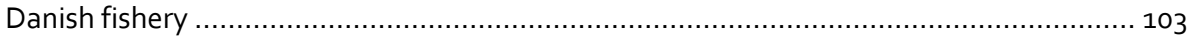

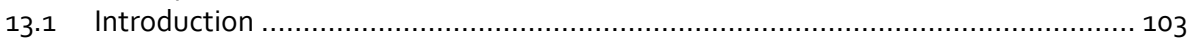

13.2 The background for the interview survey and portrait of the interviewed

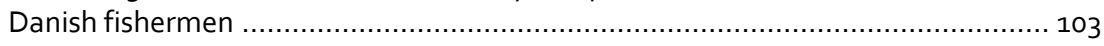

13.3 The fishermen's views about measures to reduce accidents in fisheries ................ 105

13.4 The fishermen's view about the future ...................................................111

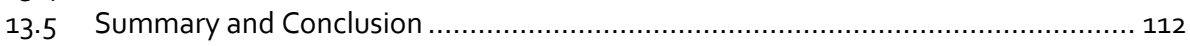

Summary - the Nordic Fishermen's view on preventive measures .................................. 115

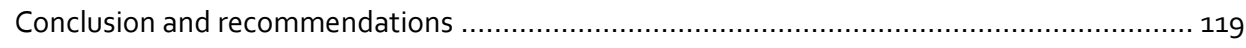

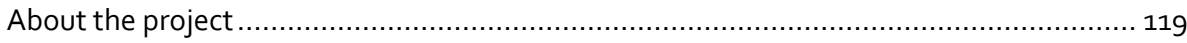

The analysis of occupational accidents in the Nordic countries ..................................... 120

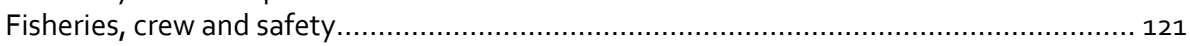

Occupational accidents, safety and prevention ................................................. 121 


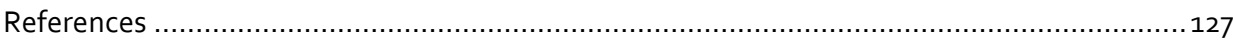

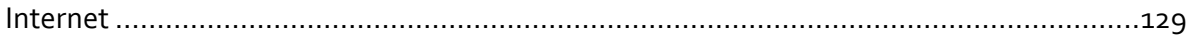

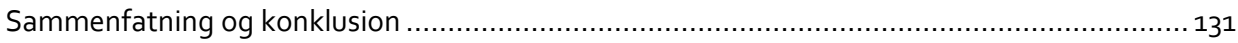

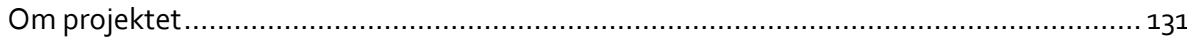

Analysen af arbejdsulykker i Norden. ............................................................ 132

Fiskeriet, besætningen og sikkerheden ............................................................. 133

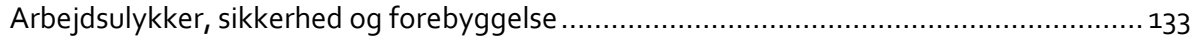




\section{Introduction}

The theme of this project has so far not been studied in the Nordic countries. Funding of the study by The Nordic Council of Ministers has made it possible to launch a project with the following objectives:

- How has the trend of occupational accidents in the Nordic fisheries evolved during the last 20-25 years?

- What has been done in the respective countries to prevent occupational accidents in fisheries?

- What has worked and influenced safety and prevention in fisheries seen from the fisherman's point of view?

The study is based on a combination of previous research and experiences from projects regarding the safety and work environment in Nordic fisheries and specific historical initiatives taken by authorities and institutions in the respective Nordic countries to promote safety in fisheries. So far there has been limited knowledge about what has worked and has positively influenced the rate and severity of occupational accidents, and there have been no investigations of the fishermen's own assessment of what actions have been preventive or would be effective. Therefore, the pilot project has been supplemented with a joint Nordic investigation of fishermen, focusing on the accumulation of the fishermen's knowledge and experience regarding actions that have played a preventive role in terms of occupational accidents in fisheries. On this basis, the results of the study have been summarised, and recommendations for national and international dissemination of the results of the pilot project have been outlined.

The project was coordinated by the following people from various Nordic countries: Jørgen Møller Christiansen, (project Manager), Senior researcher, Centre of Maritime Health and Society, SDU, Denmark. Trine Thorvaldsen, Research Scientist, SINTEF Ocean, Norway, Kim Kaustell, Research Scientist, Natural Resources Institute, Finland, Annbjørg á Høvdanum, Msc in Occupational Psychology and PhD-student at the Department of Occupational Medicine and Public Health, the Faroese 
University, and Kristinn Tómassen, Medical director, Administration for Occupational. Health and Safety, Reykjavík, Iceland. Sweden was contacted, but it was not possible to find a participant.

The answers from the respective countries to the first two questions above are in Part 1 of the report. Part 2 of the report focuses on the actions that have worked and showed a preventive impact in efforts to achieve improved safety in the fisheries. Here we give the floor to the fishermen. The joint Nordic interview study will also report the fishermen's view on what can further improve safety in the future work in the fisheries. The overall agenda of the pilot project is to provide recommendations for national and international distribution based on the results from the Nordic countries.

Finally, the authors wish to express their thanks to the participating fishermen in the Nordic countries who have made themselves available and have willingly told about their experiences with regard to the prevention of occupational accidents. Thanks to the authorities and other stakeholders in the Nordic countries for their benevolent assistance regarding the collection of data in this project. A special thanks to: The Finnish Farmers Social Insurance Institution, Faroese Accident Insurance Council, Norwegian Maritime Authority, The Icelandic transportation safety board, section on accidents at seas and its predecessor, Danish Maritime Authority, The Danish Fishermen's Occupational Health Service. Without their help, the project could not have been realised in its present form.

Figure 1: The use of Personal Protective Equipment, PPEs among fishermen have improved dramatically as can be seen on the picture. There is no doubt that PPE's have contributed to the reduction of accidents

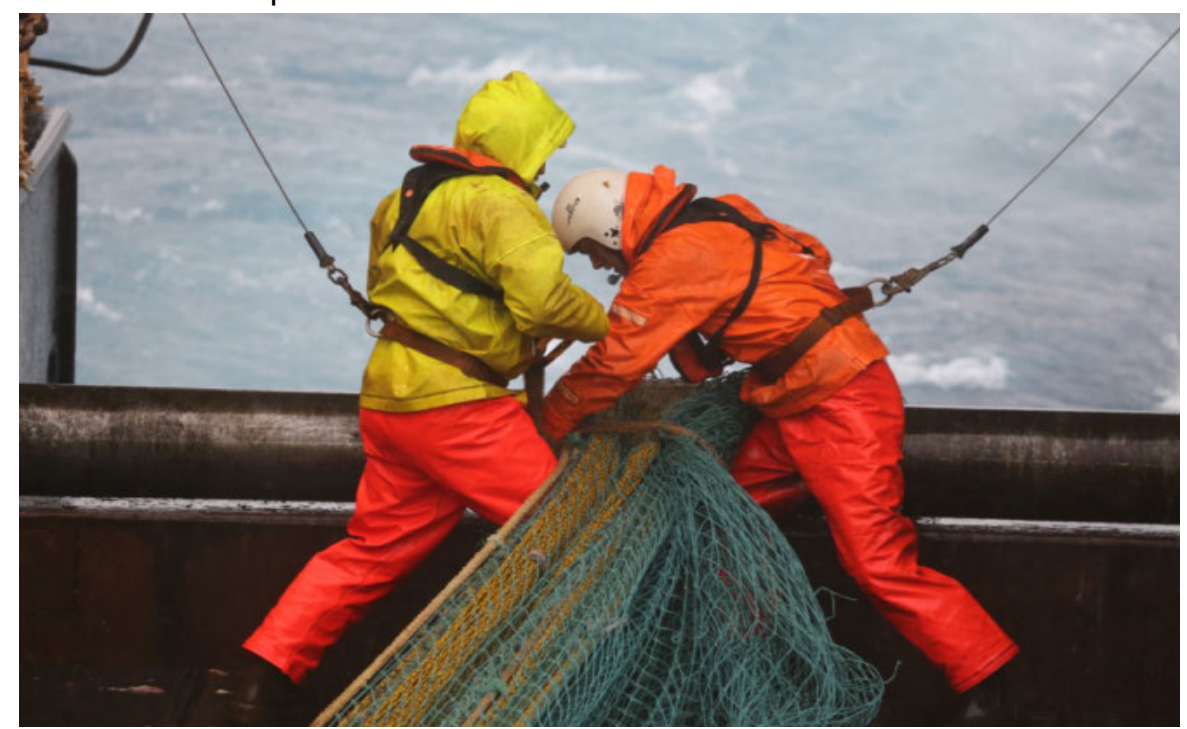

Photo: Thorgeir Baldurssson. 


\section{Part 1}


Figure 1: Fishing vessels as well fishing gear are getting of increasingly bigger size. Consequently, more safety precautions are needed. PPEs is insufficient for the prevention of all dangers

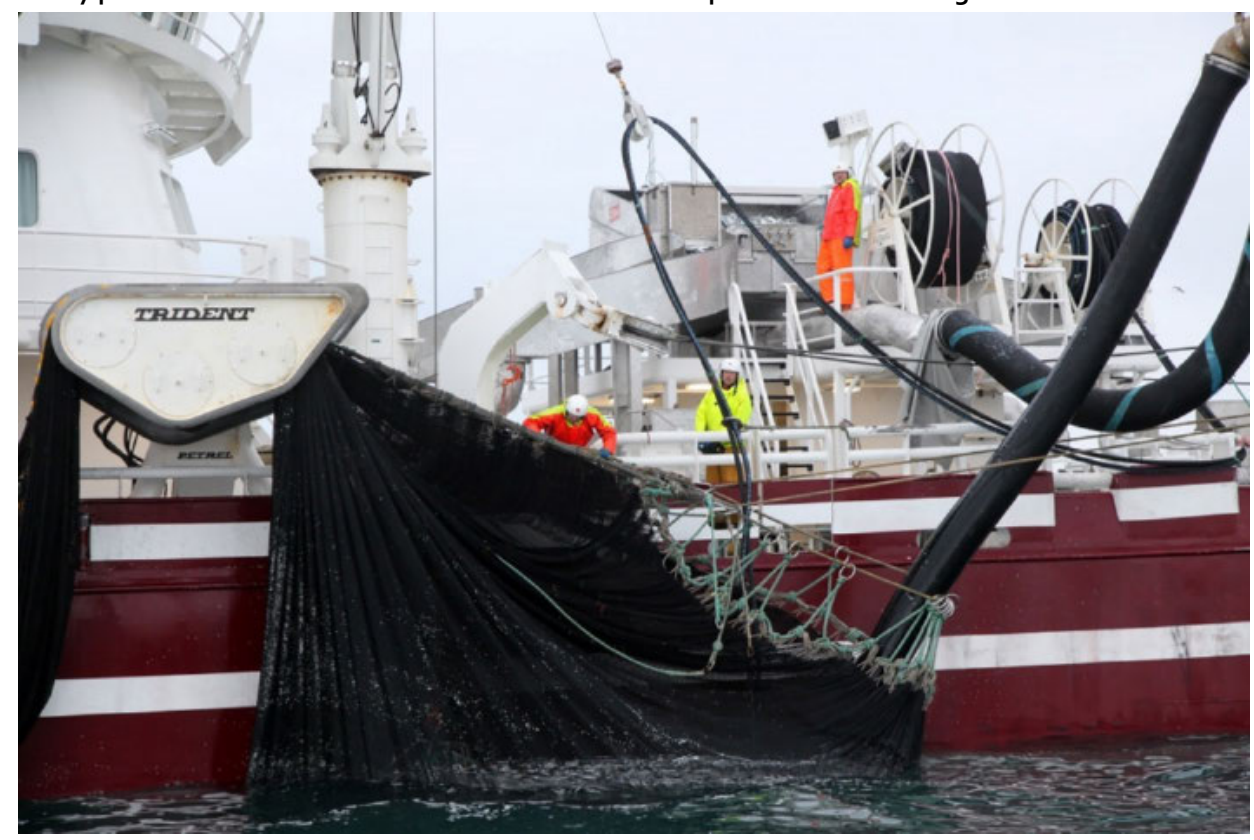

Photo: Hilmar Snorrason. 


\section{Occupational accidents and safety work in the Nordic fisheries - Developments and preventive}

measures

\subsection{Introduction}

Part 1 presents and explains the trends and developments in occupational accidents and the applied safety preventive measures during the last 20-25 years in the fisheries of the Nordic countries. The material is based on knowledge of the statistics and research that is available in each country. The contents of Part 1 will therefore differ between the participating countries, as the availability of information and research varies and therefore the existing data also vary. Following this presentation of knowledge and initiatives regarding occupational accidents in the Nordic fisheries, the fishermen then also give their view, this will be in Part 2 of the report. 
Figure 2: The gear on board gets bigger and bigger

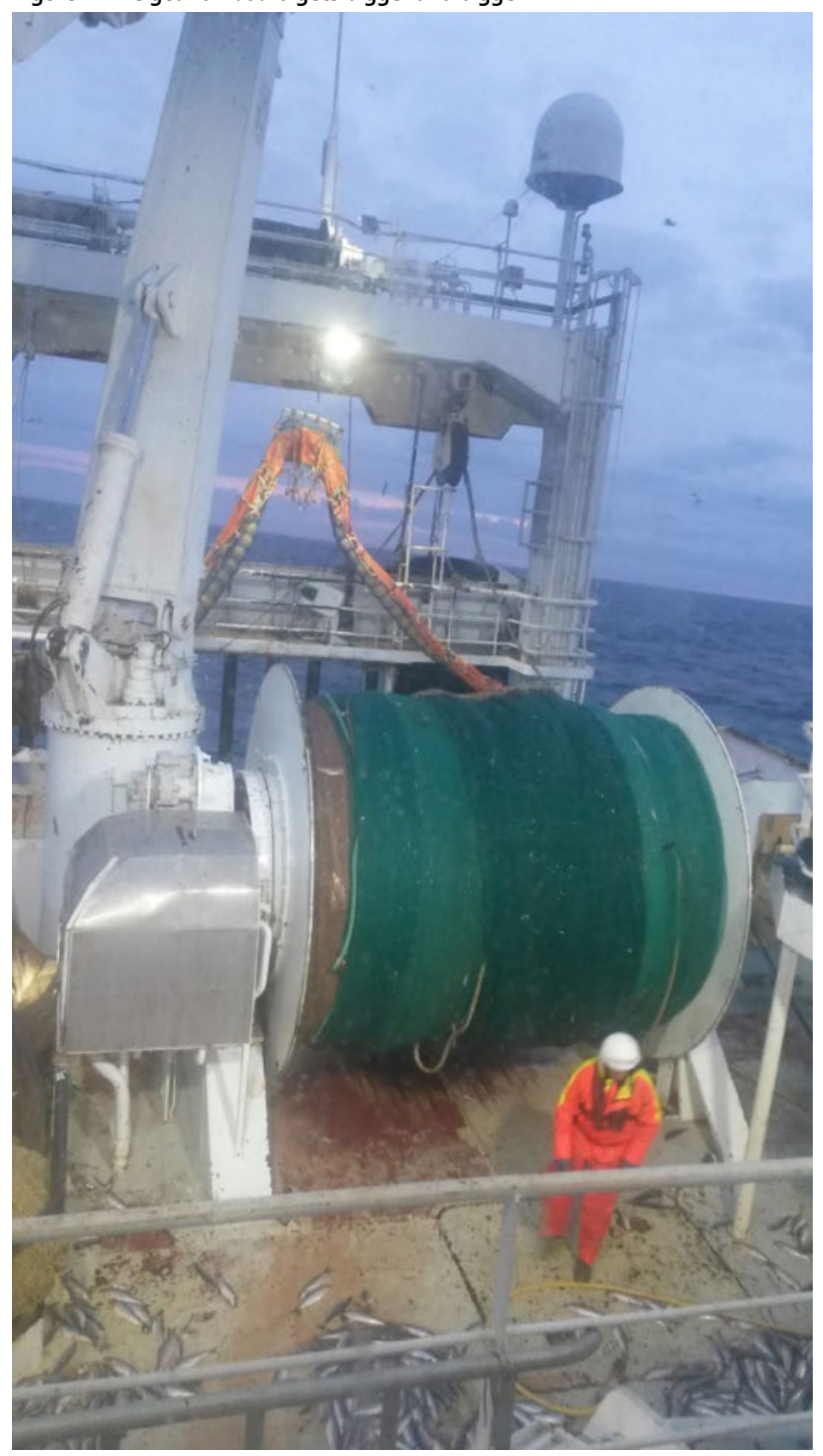

Photo: Annbjørg á Høvdanum. 


\section{Norway: Occupational accidents and safety work in the Norwegian fishery - Developments and preventive measures}

Authors: Trine Thorvaldsen and Ingunn M. Holmen. SINTEF Ocean.

\subsection{Introduction}

This chapter gives an overview of accidents in the Norwegian fishing fleet. It also describes strategies that have been used to reduce the number of accidents and improve safety for Norwegian fishermen over the years.

\subsection{The Norwegian fishing fleet}

Fishing is a large export industry, with long traditions in Norwegian society. The fishing fleet consists of a mixture of vessel types, ranging from deep-sea vessels with large crews to smaller costal vessels, many of which are operated by one fisherman.

In January 2016, there were 5,194 vessels registered in Norway. This number is taken from the official vessel registry kept by the Norwegian Directorate of Fisheries. The coastal fleet consists of vessels up to 28 metres. The majority of the vessels, 4,732 in total, are below 10.99 metres. In the category 11-27.99 metres, there are 937 vessels. In the deep-sea fleet, over 28 metres, there are 245 vessels.

According to the official registry of fishermen, there are about 11,000 occupational fishermen in Norway. In January 2016, 9,261 people were registered with fishing as their main occupation. In addition, 1,878 were registered with fishing as their secondary occupation. 


\subsection{Occupational accidents}

\subsubsection{Fatalities}

Based on the number of fatalities, fishing is commonly described as a high-risk occupation. In the Norwegian context, the risk of fatalities is high compared to other industries such as agriculture and forestry, building and construction and offshore industries (Lindøe, 2007; Lindøe et al., 2011; McGuinness et al., 2013; Aasjord, 2015).

SINTEF keeps a database of fatal accidents in Norwegian fisheries. Numbers from the database show that 306 occupational fishermen have lost their lives during the period 1990-2015. The majority of these fatalities were fishermen in the small coastal fleet, many of whom worked alone. The main causes for fatalities have been capsizing, man overboard accidents, drowning in harbour, as well as fatalities due to entanglement with machinery.

Figure 3: Fatalities in the Norwegian Fishing fleet 1990-2015

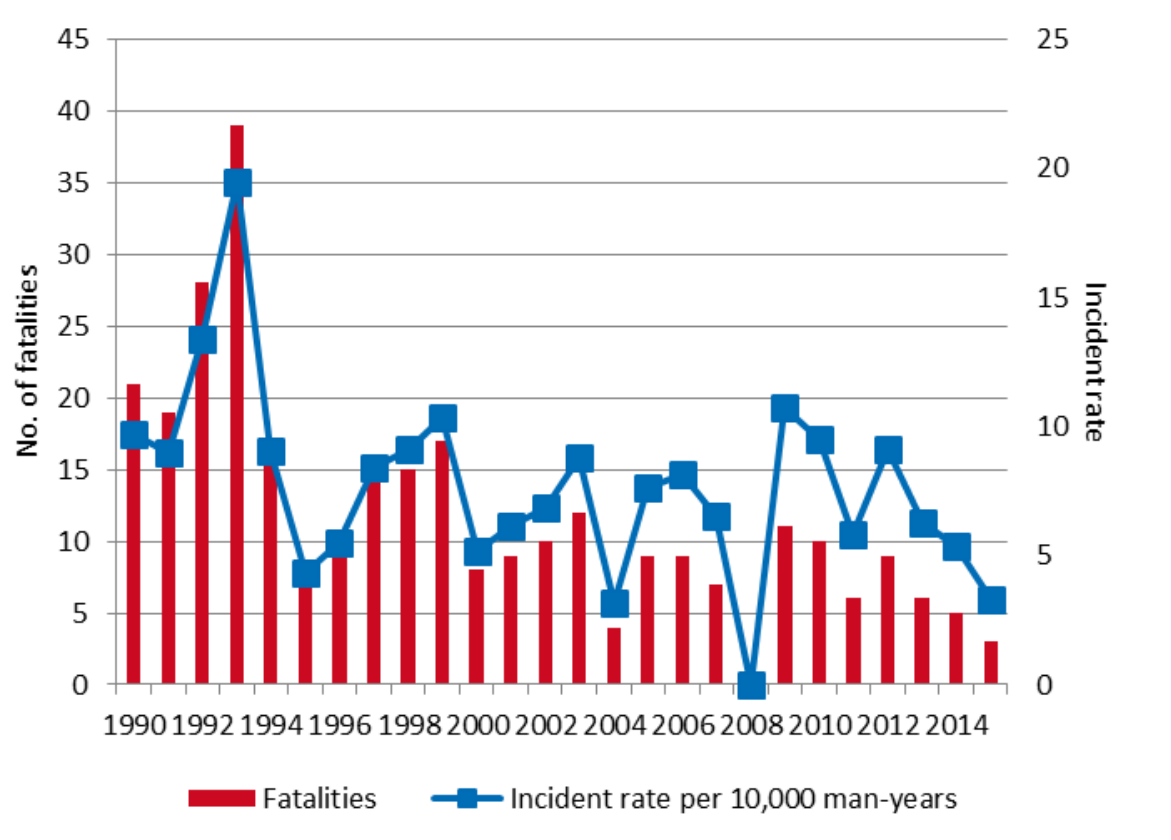

Source: SINTEF. 


\section{$2.4 \quad$ Injuries}

All work-related personnel accidents should be reported to The Norwegian Maritime Authority (NMA). The NMA defines personnel accidents as any incident resulting in physical harm to a person on board which does not do damage to the vessel. Statistics from the NMA show that the highest number of injuries is reported from the trawler fleet. However, there is reason to believe that far from all non-fatal accidents are reported to the NMA (McGuinness et al., 2013).

Figure 4: Number of reported accidents sorted by year and vessel type 2000-2015

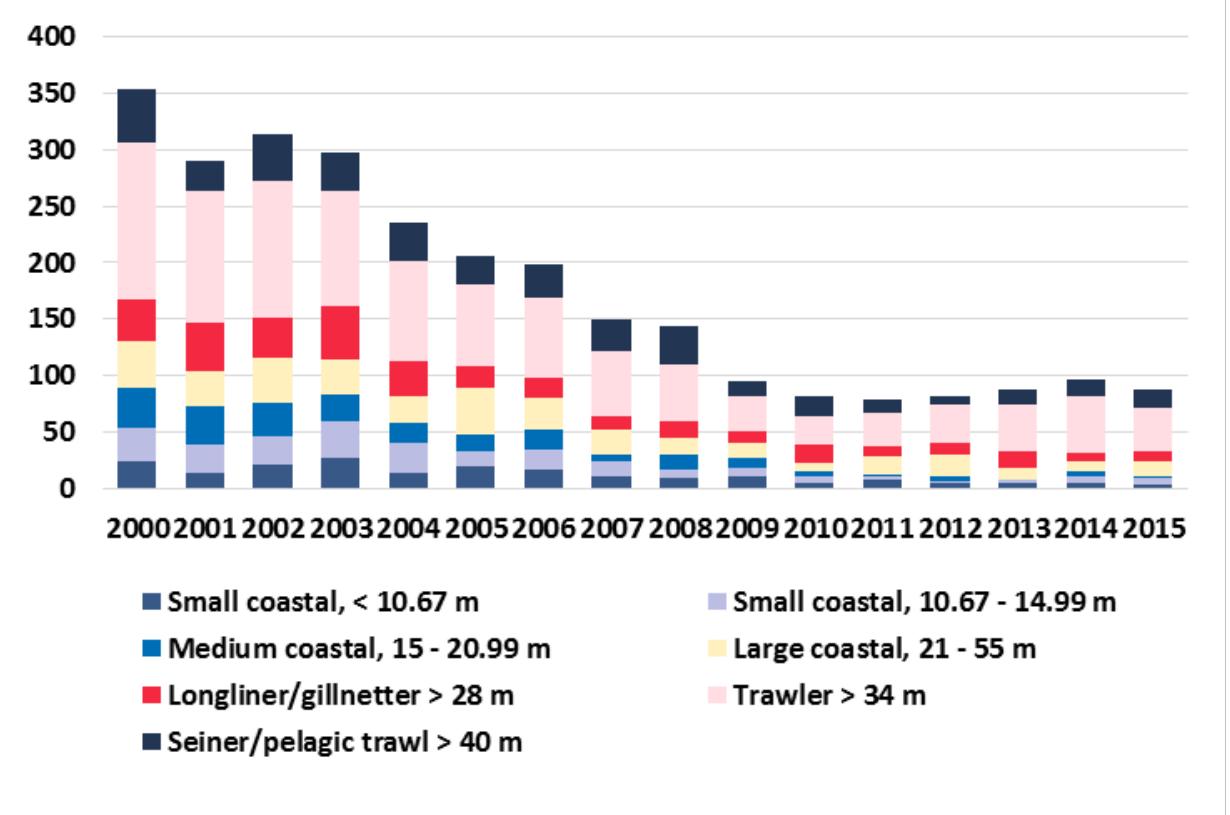

Source: Norwegian Maritime Authority.

Most reported injuries occur during work on deck, but accidents are also common during fish processing and work in the hold. The majority of the reported accidents caused an absence from work that lasted over 72 hours. The total duration of the absence is not registered, as the reports have to be handed in within 72 hours from when the accident occurred. 


\subsubsection{Causal relationships}

Causal analyses show that a given accident may be linked to several factors, such as bad weather, vessel movements and stability, cognitive and physical performance, training and experience, regulations and routines for safety work, planning and prevention, as well as indirect effects of the fisheries management (Aasjord et al., 2012; Aasjord 2015).

Many capsizing accidents have happened in bad weather. The small coastal fleet are particularly exposed to wind and waves. Vessel stability, including knowledge about loading the vessels, is also a part of this picture. Deep sea vessels are constructed to withstand harsh weather, but wind and waves affect working conditions on board these vessels as well. Sudden movement and slippery decks are often given as a direct or indirect cause of accidents in reports from fishermen to the NMA (Aasjord et al., 2012).

Long working hours and little sleep may also affect cognitive and physical performance and thus safety on board. Furthermore, the importance of safety training and on board training is essential. Fishermen need to have knowledge about the potential risks in their operations and how to perform their work safely. This also includes the use of personal safety equipment to reduce the consequences of accidents.

Rules and regulations also affect the organisation of safety work on board. In the next section, the regulatory regime for safety in fishing is described in further detail.

\subsection{Strategies for accident prevention}

The Norwegian Maritime Authority (NMA) has the governmental responsibility for safety at sea, and has stated that they want to see a development in occupational fishing similar to the safety focus in the petroleum sector (Håvold, 2010; Lindøe et al., 2011).

Safety training for Norwegian fishermen was introduced in the $80 \mathrm{os}$. In the last decade, the NMA has implemented several additional measures aimed at reducing the number of accidents, such as regulations, periodic controls and inspections, as well as informational campaigns (Aasjord et al., 2012; Thorvaldsen, 2013; Thorvaldsen, 2015).

\subsubsection{Safety training for fishermen}

In Norway, safety training became mandatory for all fishermen in 1989. Norway was one of the first countries to introduce formal safety training tailor-made for fishermen.

The STCW-F convention for fishing vessels entered into force in 2012. It was first created in 1995, being the first international requirement for training, certification and watchkeeping. In 2013, a new curriculum was introduced, making the safety training for fishermen equivalent to the IMO training for seafarers. 
Training includes theory and practical exercises on several topics, including survival, firefighting and first aid. After doing basic training, there is a specific repetition course to be completed every five years. Certificates documenting the training are controlled during safety inspections.

Decreasing accident rates in the period 1980-2006 have been linked to safety training (McGuinness et al., 2013). Fishermen and the fishermen's unions stress the importance of specialised safety training, but there have been several debates about the organisation and financing throughout the years. For instance, cuts in funding and a terminating the service of a training vessel that travelled up and down the coast, have caused some dissatisfaction from fishermen, because this reduced the availability of the safety courses along the Norwegian coast.

\subsubsection{Laws and regulations}

There are several international agreements, norms, guidelines and recommendations that aim to improve safety in the fishing fleet. The Torremolinos International Convention for the Safety of Fishing Vessels came through IMO in 1977, and marks the beginning of the Norwegian Maritime Authority's cooperation with other countries. In recent years, there has been some cooperation with the European Union. For instance, some minimal practical requirements for fishermen's health and safety is found in an EU Directive from 1993.

There have been differences in the laws for health and safety between land-based industries, offshore and fishing. In 1977 the Working Environment Act was introduced, followed by internal control in the offshore industry in 1985 and the land-based industries in 1992. Internal control made companies responsible for documenting systematic safety work. However, these regulations did not apply to fishermen.

The Seaman's law from 1975 stated that the health and welfare of the crew was the responsibility of the captain, who should inform the crew about dangers and offer suitable protective equipment. Demands for systematic safety work were introduced in 2005 in the Regulation for the work environment, safety and health for those who work on board ships. The law on ship safety from 2007 introduced further demands regarding safety in fishing.

All vessels with crews of more than seven people on board, should have a personnel safety representative and a work environment committee. For vessels with a crew of $3-$ 7 people, this is optional. 


\subsubsection{Safety management systems and risk assessments}

Safety management systems provide a way to identify and control hazards and risks in a systematic way (McGuinnes and Utne, 2014). The demand was introduced as a part of the Law on ship safety from 2007. It is applicable for vessels over 24 metres and is related to the SOLAS convention (Safety of Life at Sea) of 1929 and the ISM-code (International Safety Management) of 1993.

The paragraph on safety management systems was not applicable for fishing vessels until 2010. Now, vessels of all sizes should have such a system. From 2016, all vessels over 500 gross tons should follow the ISM code. For other vessels, the shipowners can design their own system, although a new regulation, with supplementary rules for safety management systems for vessels below 500 gross tons, is expected to enter into force in 2016.

The Fishermen's union, private consulting firms and insurance companies have made different safety management systems, which are typically paper-based templates kept in loose-leaf binders that may be made vessel-specific by the skipper and crew.

The Regulation for the work environment, safety and health for those who work on board ships states that risk assessments should be conducted on board. Hazards on board should be identified and documented, and a written assessment of the risk should be performed to identify needs for improvement. A web-based tool has been created for fishermen to perform risk assessments $(T)$.

\subsubsection{Control regime}

Fishing vessels are subjected to periodic controls as well as unannounced inspections. The aim of these controls is to make sure that fishermen comply with the formal regulations. Vessels over 15 metres are controlled by the Norwegian Maritime Authority. Vessels below 15 metres are controlled by companies that are approved by the NMA. Since 2014, these controls also apply for vessels down to 8 metres.

\subsubsection{Information campaigns}

The Norwegian Maritime Authority wants to increase fishermen's awareness and attitudes regarding safety, and has focused on information campaigns, conferences for fishermen, advertisements in newspapers, brochures, a website for occupational fishermen $(T)$ and films about safety. 


\subsubsection{Accident investigations and other measures}

The Accident Investigation Board has a marine department, which investigates all accidents leading to loss of life, to determine the circumstances and causes, with the aim of improving safety at sea and avoiding future accidents. The aim is not to apportion blame or liability. The reports give detailed descriptions of what happened, as well as safety recommendations to the authorities and the industry. Furthermore, organisations such as the Norwegian Fishermen's Association, SINTEF and other research institutions and insurance companies have all worked to improve safety in the fishing fleet over the years.

\subsection{Summary}

In the period 1990-2015, 306 occupational fishermen lost their lives in Norway. The majority of these fishermen worked in the coastal fleet, and many worked alone. The main causes for fatal accidents in the Norwegian context has been capsizing, man overboard accidents, drowning in harbour and entanglement with machinery.

Reports to the Norwegian Maritime Authority show that trawlers report the highest number of non-fatal injuries. Injuries that are reported to the authorities commonly lead to an absence from work of more than three days, indicating that less serious accidents might not be reported. Injuries often occur during work on deck, fish processing on board and work in the hold.

Safety training was introduced in the 1980s. In the last decade, The Norwegian Maritime Authority has implemented regulations, periodic controls of vessels, as well as informational campaigns aimed at reducing the number of occupational accidents in the Norwegian fishing fleet. The Norwegian Accident Investigation Board investigates all fatal accidents and marine accidents. Fishermen's associations, research institutions and insurance companies have all worked to improve safety over the years. 


\section{Finland: Occupational accidents and safety work in the Finnish fishery-Developments and preventive measures}

Authors: Kim O. Kaustell, Tiina E.A. Mattila and Risto H. Rautiainen Natural Resources Institute Finland.

\subsection{Introduction}

In Finland, the number of registered fishermen has decreased from 3,943 in 1998 to 2,473 in 2014 . Around $80 \%$ of the registered fishermen catch fish in the coastal region, while the rest fish on the big inland lakes and waterways. The proportion of part-time fishermen among coastal fishermen has increased from $60 \%$ to $77 \%$ (Figure 5). The average age of fishermen in the coastal area was 47.4 years in 1996; twenty years later it was 57 years.

The catch comprises perch, white fish and pike-perch in coastal water areas with nets and fyke-nets. However, the most important catch is Baltic herring, which is mainly caught by trawlers in open sea areas. The economic value of the Baltic herring catch was EUR 28 million in 2014. The total fish catch of commercial fishermen from sea areas was 148 million $\mathrm{Kg}$, and about EUR 40 million in 2014 (Official Statistics of Finland: Commercial marine fishermen, 2016). 


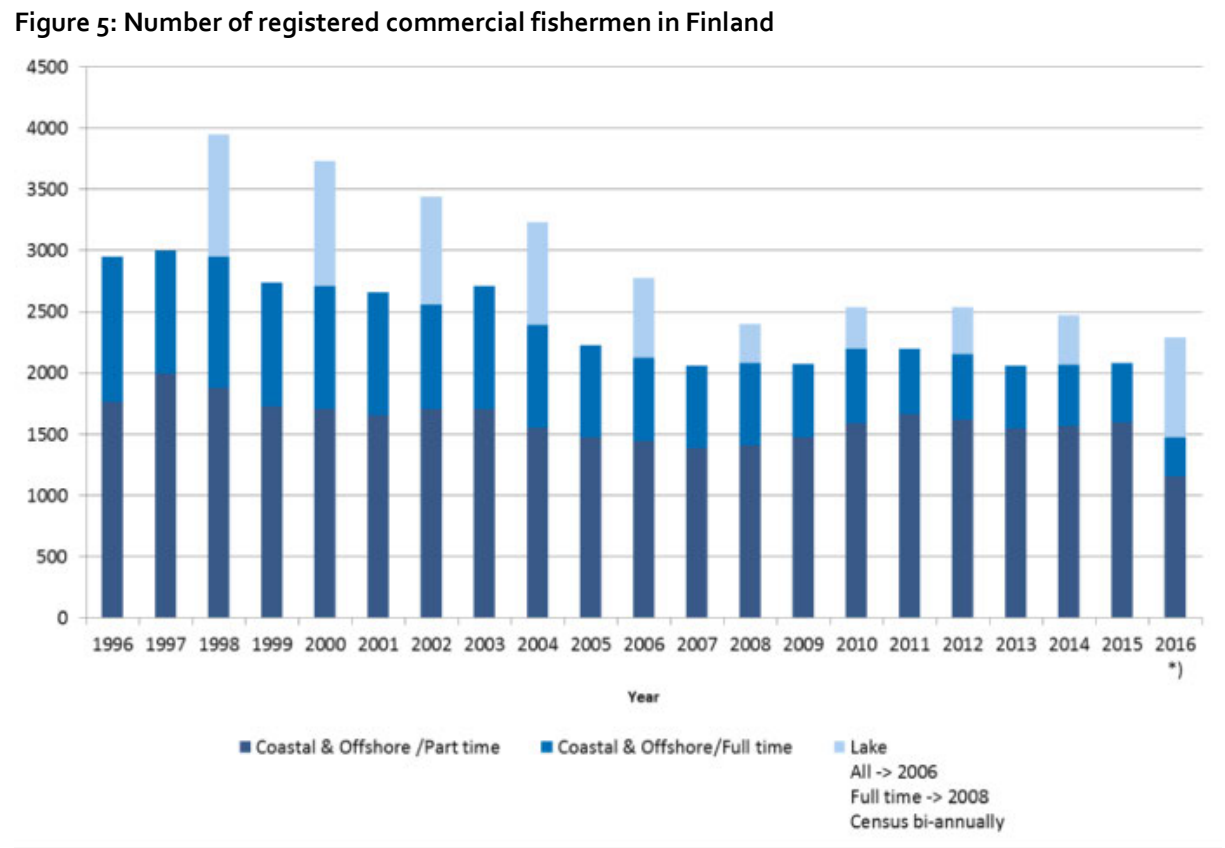

Note: *) New registration method in 2016: Class I (full time), fishing income lower limit is 10,000 EUR/year, both for coastal/offshore as well as lake fishing.

Source: Official Statistics of Finland: Commercial marine fishermen (2016).

Official Statistics of Finland: Commercial inland fishermen (2016).

Vessels used for commercial fishing are typically small; less than 12 metres (Figure 6). It is mandatory to register vessels used for commercial fishing in the coastal and offshore areas. On lakes, registering is not mandatory, but it is required in order to get tax refunds for fuel, as well as for the vessel to be eligible for investment subsidies. 
Figure 6: Number and LOA (length over all) of registered coastal and offshore fishing vessels in Finland

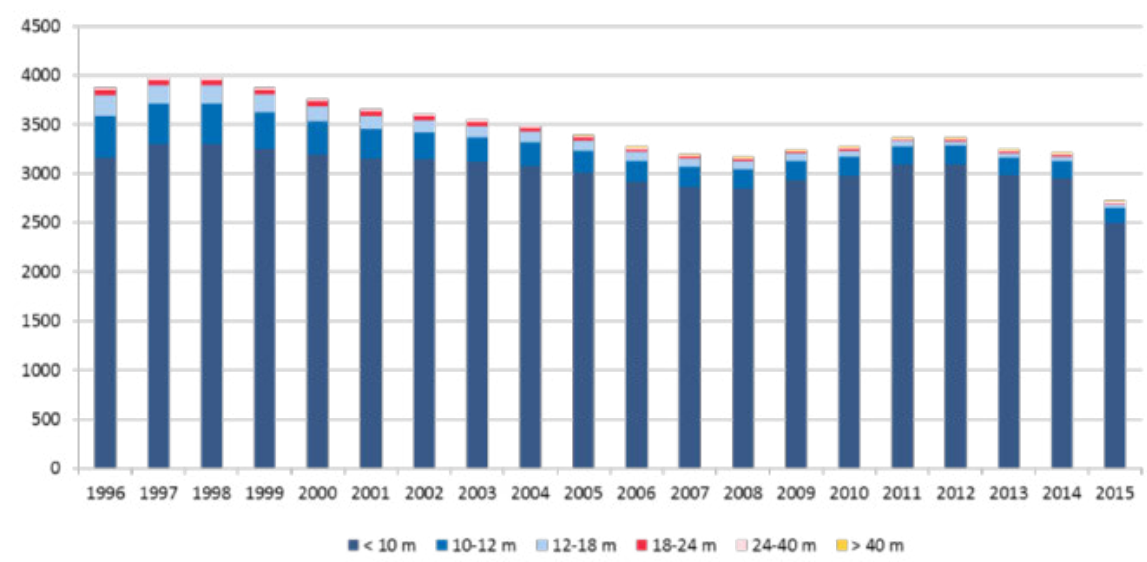

Source: Official Statistics of Finland: Commercial marine fishermen (2016).

Figure 7: A large part of the Nordic fleet consists of small vessels

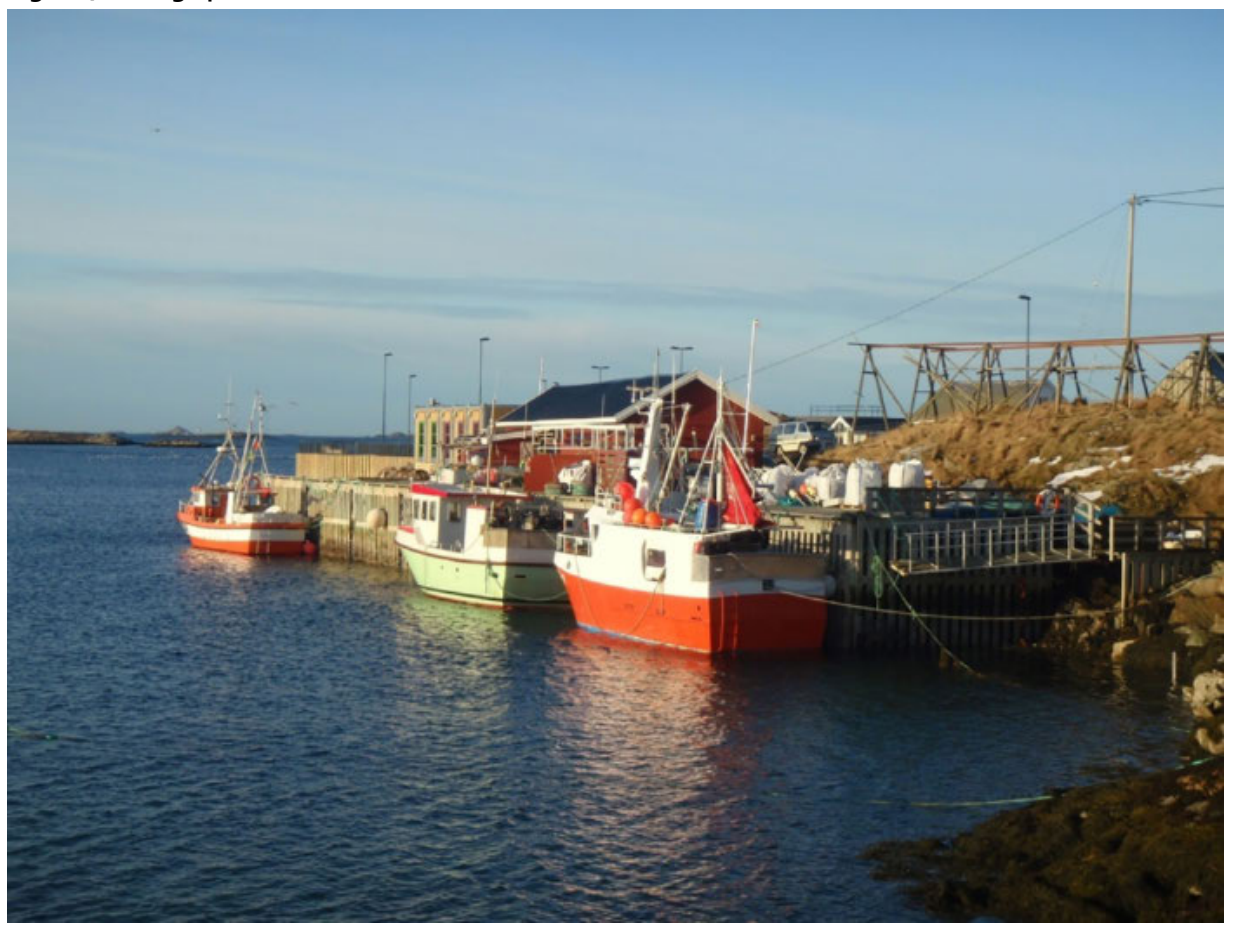

Photo: Trine Thorvaldsen. 


\subsection{Occupational injuries}

The Finnish Farmers Social Insurance Institution's (Mela) accident insurance (Mata) is mandatory for all self-employed fishermen and their family members, if they pay tax from their fishing income and this income is at least EUR 3,770 per annum (2016 level). The Mata insurance system does not cover small-scale fishing, fishing outside the territorial waters of Finland, salaried fishermen and most of the fish farming. In 2014, $24 \%$ of all commercial fishermen were covered by the Mata insurance.

The data we used in this study originates from the Mata database. It comprised injury descriptions and demographic information from insurance claims lodged by Mata -insured fishermen during the years 1996-2015, altogether 1,954 people. They had suffered 1,135 compensated injuries, including 11 fatalities and 53 occupational diseases. Injury, in this context, indicates physical (or mental) harm to the subject as a result of a sudden, unexpected, external event. As a result of an accident, the subject can get injured and/or there can be other damage costs that may be compensated (e.g. glasses). The data used only comprised injuries that needed medical attendance. The detailed data descriptions and results have been published by Kaustell et al. (2016).

\subsubsection{Materials and methods}

The MaTa insurance data was anonymised and included the following information on all insured persons: gender, age, mother tongue, income, home county, as well as information on insurance start and ending dates, voluntary occupational health service membership and sum of compensated injuries. The injury data comprised information on date and location of the incident, the victim's age at injury, details of the work activity, injuring agent, cause, injured part of body, type of injury/illness, ICD-10 coded diagnosis, length of disability and a short description of the injury/illness incident. Numeric and coded data were used for descriptive statistics, and incident descriptions were analysed and categorized for additional insight into causation.

The MaTa insurance data does not include information on person-work years, nor does it distinguish between full-time or part-time occupation fishermen. This ratio (fulltime vs. part-time) was estimated using the ratio indicated in the register of all commercial coastal fishermen. The calculation of person-work years is based on the assumption of main occupation fishermen accounting for 0.9 person-work years per annum, and part-time occupation fishermen accounting for 0.45 person-work years per annum, as used by McGuinness et al. (2013). 


\subsubsection{Results}

The mean age of the injured fishermen was 47.6 years. The age distribution ranges from 21 to 73 . Most of the injuries happened to fishermen in the age category 45-54 years (Figure 8). The work experience of injured fishermen varied from 0-41 years (median 14 years, mean 14.9 years). Four of a total of 552 injured persons were family members of the insured fishermen. Based on the short injury description, approximately $40 \%$ of all fishing-related injuries occurred while on fishing vessels/boats or when boarding/exiting the vessels/boats. The rest ("other") occurred ashore, on sea or lake ice during fishing activities, or the location could not be identified.

Figure 8: Total number of injuries and insured fishermen by age range in 1996-2015 in Finland

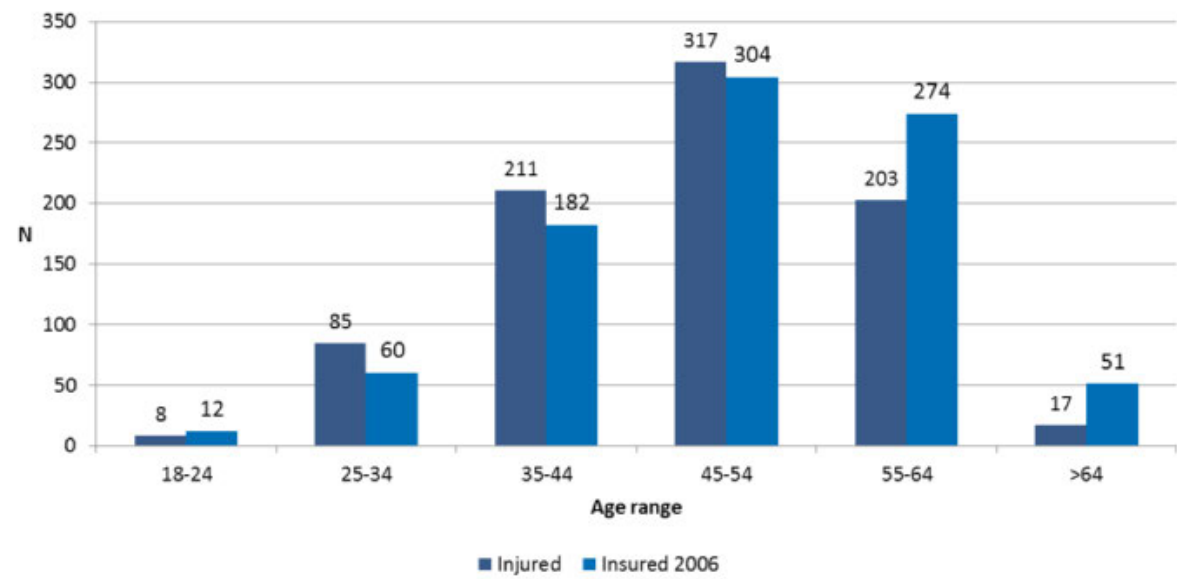

Note: For the number of insured fishermen per age range, the year 2006 count of insured fishermen has been used as a reference.

Source: The Finnish Farmers Social Insurance Institution's (Mela) accident insurance (Mata) data.

\subsubsection{Non-fatal injuries}

There were a total of 833 non-fatal occupational, fishing-related injuries during the observed period; $91 \%$ of these occurred to males and $9 \%$ to females. Compared to the gender ratio among all insured fishermen ( $85 \%$ and $15 \%$ respectively), injuries that happened to males are over-represented. This is likely due to the division of work tasks by gender.

Finland is a bilingual country, and the majority of the Swedish-speaking part of the population resides in coastal areas. $24 \%$ of the observed injuries happened to Swedishspeaking fishermen, while the proportion of Swedish-speaking fishermen among all in- 
sured fishermen is $34 \%$. The same under-representation of the Swedish-speaking population in the injury statistics has also been observed in other studies dealing with injuries, e.g. in agriculture.

The estimated average injury rate was 7.9 injuries per 100 person-work years, with a slight downward trend over the observed period. The average sick leave resulting from injuries, excluding occupational diseases, was 82.7 days (median 21 days).

The type of work done by the victim has been recorded on a coarse level in the injury claims data used. The records show that trawling accounts for $15 \%$ of injuries, while other fishing methods (e.g. nets and fyke-nets) and other fishing-related work are predominant work types. The most typical work tasks during injuries were maintenance and repair of equipment (20\%), and handling, transport and storage of fish (16\%).

The most typical deviation that led to an injury was falling to a lower level (Figure 9). The main cause of injuries was slipperiness of the terrain, including ice on landings etc. (Table 1). The injured part of body was typically upper limb (44\%), lower limb (23\%) or back (17\%) (Table 2 ).

Figure 9: Deviation types "top ten" for insured fishermen in 1996-2015 in Finland
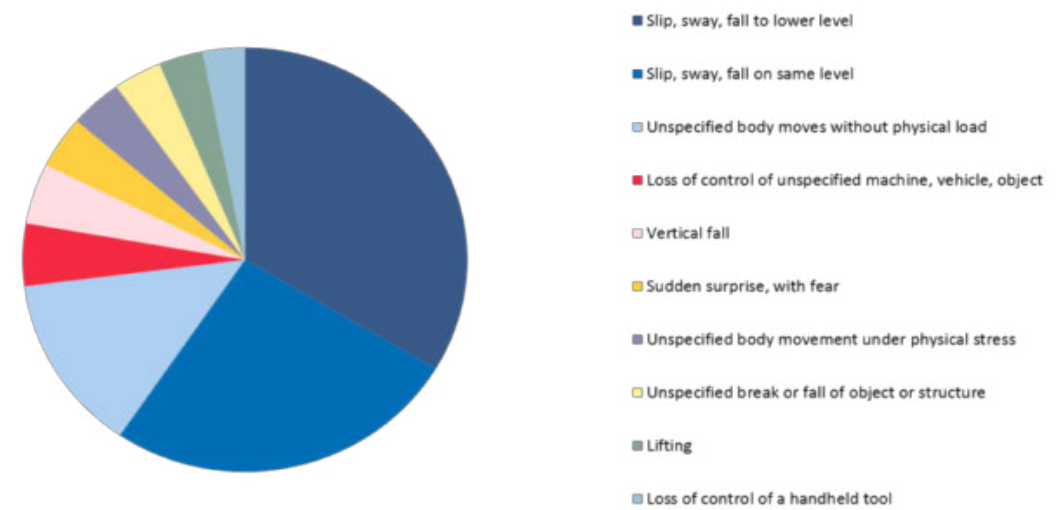

Note: The presented ten deviation types account for 652 or $78 \%$ of the identified non-fatal injuries.

Source: The Finnish Farmers Social Insurance Institution's (Mela) accident insurance (Mata) data. 
Table 1: Cause of injury for insured fishermen in 1996-2015 in Finland

Injury cause

Slippery terrain/ice

Floor, aisle, deck, doorstep

Sudden movement, posture

$12 \%$

Boat, vessel

Knife, chisel

Fishing gear and equipment

Wind, rough seas

Wild animals, insects

Other unclear machines and equipment

Other buildings and constructions

Snow scooters and sledges

Uneven terrain

Other movements and postures

Stones, tree stumps and other heavy objects

Skidding and other loading devices, winches

Other raw materials

Trucks, cars, vans, fork lifts

Other outside environment factor

Other causes

Missing

$\begin{array}{rr}122 & 15 \% \\ 103 & 12 \% \\ 63 & 8 \% \\ 50 & 6 \% \\ 38 & 5 \% \\ 36 & 4 \% \\ 25 & 3 \% \\ 25 & 3 \% \\ 23 & 3 \% \\ 22 & 3 \% \\ 20 & 2 \% \\ 20 & 2 \% \\ 16 & 2 \% \\ 13 & 2 \% \\ 11 & 1 \% \\ 11 & 1 \% \\ 10 & 1 \% \\ 10 & 1 \% \\ 218 & 26 \% \\ 5 & \end{array}$

Source: The Finnish Farmers Social Insurance Institution's (Mela) accident insurance (Mata) data.

Table 2: Injured part of body of insured fishermen in 1996-2015 in Finland

$$
\text { Injured part of body }
$$

Upper limbs

Lower limbs

Back

Body, internal

Head

Whole body, multiple trauma

Neck, throat

Missing

$365 \quad 44 \%$

$196 \quad 23 \%$

139

$71 \quad 8 \%$

$46 \quad 6 \%$

$10 \quad 1 \%$

$9 \quad 1 \%$

Source: The Finnish Farmers Social Insurance Institution's (Mela) accident insurance (Mata) data.

The most common types of injuries were dislocations sprains and strains (40\%), wounds and superficial injuries (25\%), bone fractures (16\%), and concussions and internal injuries 16\%. The remaining injury types represent frequencies less than 2 per cent (Table 3 ). 
Table 3: Type of injury of insured fishermen in 1996-2015 in Finland

Type of injury $\mathbf{N}$

Dislocations, sprains and strains

Wounds and superficial injuries

Bone fractures

Concussion and internal injuries

Other specified injuries

Burns, scalds and frostbite

Traumatic amputations (Loss of body parts)

Multiple injuries

Poisonings and infections

Effects of reduced temperature

Shock

Acute hearing loss

Unknown or unspecified

Missing

Source: The Finnish Farmers Social Insurance Institution's (Mela) accident insurance (Mata) data.

\subsubsection{Fatalities}

There were eleven fatalities during the period, fluctuating from o to 3 per annum. The most recent fatal injury to MaTa-insured fishermen occurred in 2007. All fatal injuries were drownings (may have also had other injuries) and all the drowned fishermen were men, mean age 42 years. The particular causes or chains of events that led to the drownings are not known. Storm was mentioned in two injury descriptions. Seven happened in October or November, one in February and three in April/May, all during open water (not while fishing on ice).

\subsection{Measures taken to prevent accidents and injuries}

In a background study, looking for measures to promote occupational safety in commercial fishing, the following occupational safety-promoting activities have been identified:

\subsubsection{The Occupational Healthcare System (OHS)}

In Finland, OHS is voluntary for entrepreneurs and compulsory for salaried workers. The employer has to organise OHS services for the hired personnel. The service was started for farmers and fishermen in 1984, and it is provided both in private and also in municipal health care centres. In 2015, 14\% of all MYEL-insured fishermen had joined the OHS 
( $14 \%$ of men and $25 \%$ of women). The corresponding Figures were $8 \%$ and $12 \%$ for the years 1996 and 2006, respectively.

The service costs about EUR 50 to 100 per fisherman, and includes a working place visit/safety check (recommended every 4 years) and health check (recommended every 1-2 years). It is financially supported and in practice, workplace visits/safety checks are free for fishermen. Health checks are also partly supported (50-60\%). In 2009, fifteen fishing experts were trained to perform safety checks in fisheries, so that they can join the working place visits, along with the healthcare specialist.

\subsubsection{Education and training}

Depending on the geographical (fishing) area, vessel size and size of business, various kinds of training and certification (also in safety matters) may be mandatory. The majority of registered fishermen are self-taught, following family tradition.

The vocational training of a fisherman comprises 180 study points, corresponding to 3 years (after secondary school) or 2 years (for students) of full-time studies. The curriculum includes several periods of practical work and tests. The training comprises, among other profession-related matters, all needed subjects of the topic to acquire a basic commercial ship operator's certificate - including knowledge of occupational safety regulations, safety management and first aid. This training is also available for adults.

More comprehensive training, e.g. a seven day safety course for operators, skippers and personnel on vessels bigger than $24 \mathrm{~m}$, is arranged when needed. Short, one day safety courses are also commercially available.

\subsubsection{Social insurance company activities}

Mela (The Farmers' Social Insurance Institution) produces and disseminates common guidance (e.g. flyers, brochures, online material, videos) for better occupational health and safety, but this material is not specially customised for fishermen. Mela also supports rehabilitation after injuries and when the person's work ability and possibility to continue at work are seriously at risk. Machines or devices that support possibilities to continue in the profession are partially subsidised. 


\subsubsection{Mandatory regulations regarding safety}

Ordinary occupational safety regulations apply when using salaried workers. Unfortunately, the overwhelming majority of Finnish commercial fishermen are self-employed entrepreneurs. The law on onboard staff and safety management of the vessel states that:

- "People working on fishing vessels >10m (>12m on domestic coastal) must be trained in safety matters"

Due to the size distribution of the Finnish fishing fleet, more than $90 \%$ of it falls under the size limit set by the law.

A ship operator's and a skipper's licence are required depending on the operated sea area and the vessel size (>12 $\mathrm{m},>24 \mathrm{~m})$. The training for different level licences comprises, e.g. for navigation and ship handling, the following safety-related modules:

- Operation during emergency evacuation.

- Firefighting.

- First aid.

\subsubsection{Campaigns etc. by miscellaneous actors}

In 2005, the Safety Investigation Authority (SIA) started an investigation of ten fishing vessel accidents. Lives were lost in three cases. Six ships went under; two were later retrieved. The investigation concluded that, e.g.:

- "There are several possibilities to develop fishing vessel structures and equipment to accomplish better safety."

- "Many interviewed stakeholders agree on the fact that positive safety development is hampered by financing problems."

- "Public support should be directed to safety-promoting measures for single manned fishing units."

The Central Union for the Fishing Industry and the Association of Commercial Fisheries have from time to time initiated small scale campaigns, e.g. a small project concerning OHS for fishermen (education, training and informing) in 2009, and in 2015, a descriptive study on injuries in commercial fishing (Mäkinen, 2015). 
The Natural Resources Institute Finland initiated in 2014 a Norwegian-Finnish pilot project called "Health, Safety and Environmental Competence Among Fishermen in Botnia and Nordland" (Kaustell et al., 2014).

\subsection{Summary}

Being a commercial fisherman (as opposed to leisure/pleasure fishing) is a traditional occupation in Finland. Besides catching fish, it also includes fish refining, as well as selling fish and fish products. Pluriactivity, i.e. practising agriculture, farm tourism, or the like, along with fishing, is common among Finnish fishermen. For the studied fisherman population, $26 \%$ of all injuries happened during activities that were not related to work in the fishery. These were not included in this injury data study. Pluriactivity, small-scale and seasonal fishing (Salmi, 2005), and fishing on ice, are special characteristics of fishing in Finland.

The fishing occupation nowadays faces many pressures, e.g. economical and regulatory. These and other factors have led to the profession losing the interest of young people. Commercial fishermen are thus an ageing population, which is one significant background factor to be taken into account when planning and executing injury prevention interventions.

The injury rate has had a slight, but not significant, falling trend over the studied period. Still, it is above the mean value for agricultural entrepreneurs and well above the mean for all industries. Fishermen also have longer average sick leave durations than most other occupations. Many of the fishing-related activities happen ashore, which can also be noticed in the injury data.

Both fish handling and storage, and also maintenance and repair of fishing equipment, structures and buildings, should receive more attention with preventive measures. Mental strain and fatigue should be taken into account, as well as health problems that come with age. Fatigue has been found to be a serious health and safety problem among fishermen (Høvdanum et al., 2014). The main focus should be aimed at preventing slips, trips and falls - both on board and ashore.

A central problem for injury prevention among commercial fishermen in Finland is how to reach and motivate the fisherman population to adopt safer ways of working. This would probably require concerted actions of all interest groups: the fishermen's trade organisations, the Occupational Healthcare Services, the insurance companies and authorities governing both sea safety and fishing-related regulations and funding. 
Figure 10: The fishermen has dangerous work tasks every day. Even a small mistake can have lifetime consequences

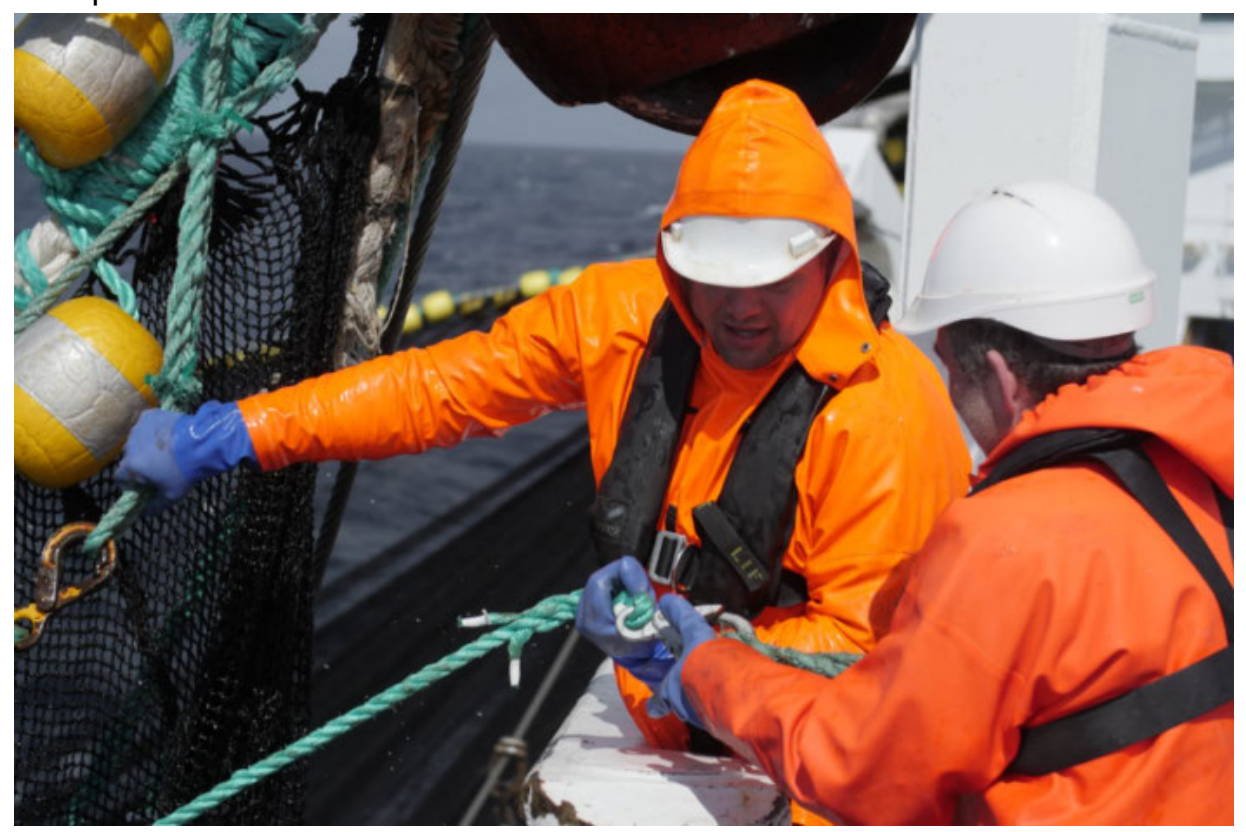

Photo: Thorgeir Baldurssson. 


\section{The Faroe Islands: Occupational accidents and safety work in the Faroese fishery - Developments and preventive measures}

Author: Annbjørg á Høvdanum, Department of Occupational Medicine and Public Health, Faroe Islands and the Faroese University, and Olaf Jensen, Centre of Maritime Health and Society, University of Southern Denmark

\subsection{Background}

This document provides an overview of accident statistics in the Faroese fishing fleet. Furthermore, strategies that reduce the accidents and improve safety in faroese fishing are outlined.

We would like to thank the following for financial support for the project: The Faroese Health Research Foundation, The Faroese Engineers' Union and The Faroese Navigator Union.

\subsection{The Faroese fishing fleet}

The fishing industry is the main source of income for Faroese people, accounting for over $90 \%$ of the Faroese exports (Høvdanum, 2016; R).

The Faroese fishing fleet consists of a mixture of vessel types, ranging from deepsea vessels with large crews, to smaller vessels with only one fisherman. In September 2015 , there were 623 vessels with a fishing licence in the Faroe Islands. The Table below lists the 412 vessels that are using their fishing permit, sorted by type of fishing. 
Group 2 Trawlers

Group 3 Longliners $>110 \mathrm{t}$

Group 4A, Vessels from 15-40 t

Group $4 \mathrm{~B}$, Vessels $>40$ t with longline

Group $4 \mathrm{~T}$, Vessels $>40 \mathrm{t}$ fishing with trawl

Netting vessel, in Faroese territorial sea

Group 5 A, Fishing boat $<15$ t fishing full-time*, angling

Group $5 \mathrm{~B}$, Fishing boat, < 15 t part-time fishermen, angling

Purse seiner

Note: *Fishing full-time means that they have an income of minimum DKK 400,000, before expenses are paid. Fishing boats in group $5 \mathrm{~A}$, have used 883 fishing days in the fishing year 1 st Sept 2015-1st Sept 2016 , which is on average 42 days per ship, while group $5 B$ have used 4,343 days, which is on average 14 days per ship.

Source: The Faroe Islands Fisheries Inspection (B).

\subsection{Accident statistics}

In 2013, there were about 2,239 active fishermen in the Faroe Islands (A, 2016; B, 2016). The Faroese fishermen are obligated by law to report all accidents that result in more than a one-day absence from work to the Faroese Maritime Authority (FMA). However, from 2011 until now, 11 accidents have been reported. This is a major under-reporting. Høvdanum et al. (2016) reports that, from 2011 to 2014, 93 accidents were reported to the Faroese Accident Insurance Council (FAIC). The FAIC is the most comprehensive dataset of fishermen's accidents in the Faroe Islands and will therefore be used in favour of the FMA database. Undoubtedly these statistics are still lower than the actual Figures, but the downward trend is likely to be true. Using insurance data holds the risk that the formulation of claims is motivated by receiving compensation. However, knowing that there might be some uncertainties regarding the data, maybe especially regarding compensation for glasses, it is still the best data available. In addition, the Faroese accidents investigated by the Danish Maritime Accident Investigation Board (DMAIB) or the FMA will also be commented on. To clarify, data reported to the FAIC is not rated by seriousness, so when the phrase "serious accidents" is being used, it is referring to accidents that have been investigated by the DMAIB or the FMA. 
Figure 11: M/S Tjaldrid on fishing control off the Faroe Islands. All accidents must be reported to the authorities (FMA). While major incidents such as death or economic loss on a larger scale are mostly notified, minor accidents may not be reported. This issues is now in focus, and attempted changed in the Faroe Islands

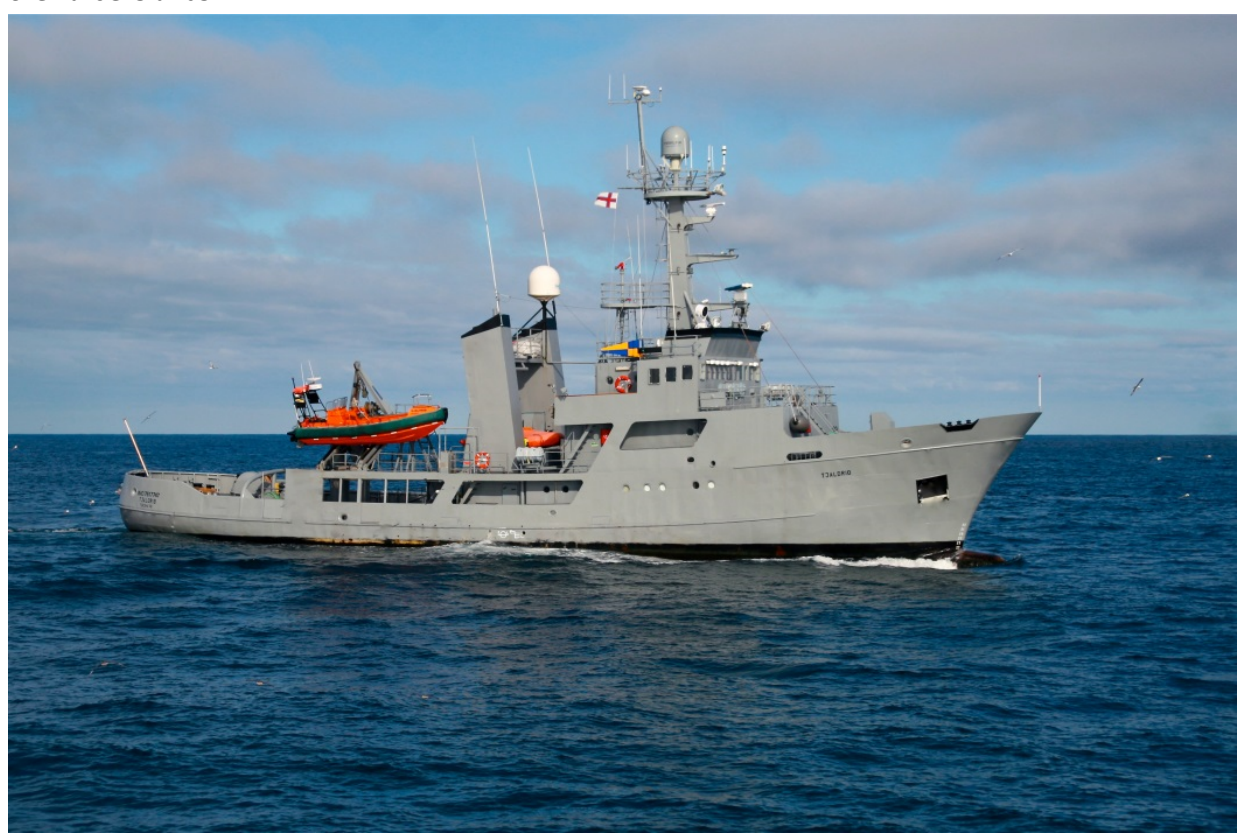

Photo: Aksel á Botni.

The FAIC study reviews and extracts relevant information from every accident log from 1972-2014. For example: age, date, time, job title, ship type, place on ship, injury mechanism and type of injury. From 1972 to $2014,12,619$ work accidents from all branches were reported to the FAIC. $33 \%$ of these accidents were from the maritime field. 3,324 were in fishing, and a small proportion was in the merchant fleet. The data also show that 77 occupational fishermen have lost their lives (Figure 12). If we calculate with the assumption, that the fishermen work 175 days a year, then there is 1 fatal accident per 1000-man years, and if calculated with a work year being 200 days, then we got 1.15 fatal accidents per 1000 man-years. This is a bit higher than the other Nordic countries (Jensen et al., 2014). 
Figure 12: All accidents in the Faroese fishing fleet from 1972 to 2014, including fatal accidents

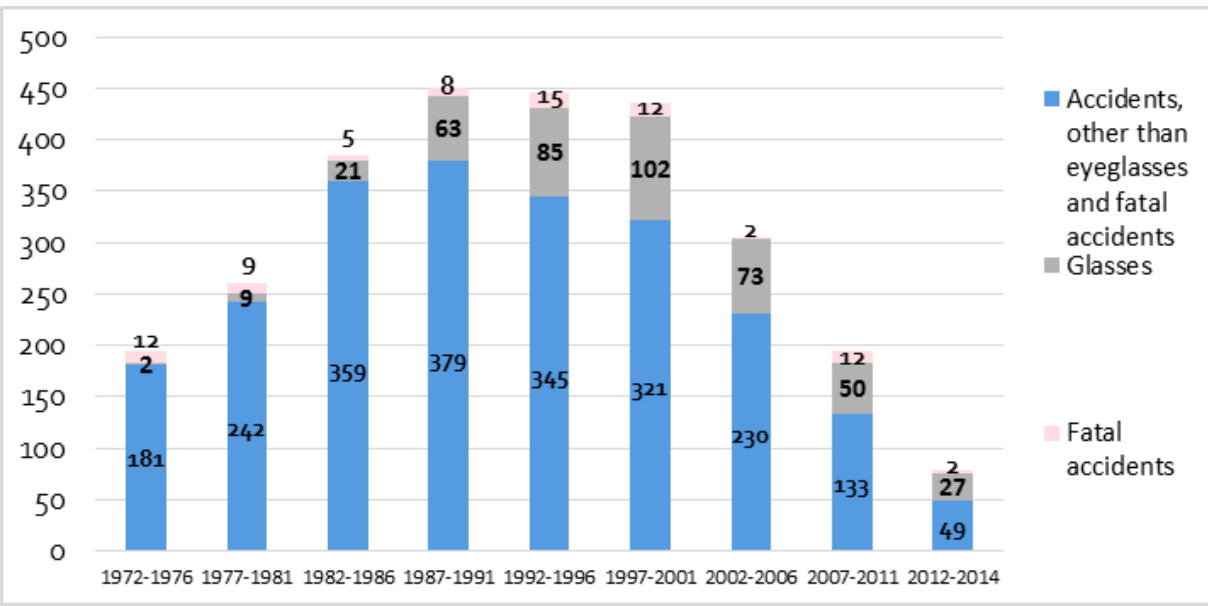

Note: Statistics from 2013 and newer should be viewed with caution, as the processing of the accident claims takes a long time, especially the more complicated cases.

Source: The Faroese Accident Insurance Counsel.

The Figure above illustrates a stable decline in the number of accidents. The rate peaks in the 1990 s and then reduces, with no year having more than 30 accidents after 2010. The data show that up to 2012 there has been a positive development in the frequency of reported accidents. From 2000 to 2012, reportings indicate a reduction of accidents by almost $50 \%$, despite a significant increase in reports about glasses. It could be postulated that peaks in the 1990 were due to the economic crisis in the Faroes. Catching little fish for many years in a row meant that companies were struggling so not all could afford the maintenance of their vessels and therefore the accident risk is expected to have increased. It may also be that accidents were reported more because fishermen who previously would have taken time off when unable to work were more reliant on not losing their already low income.

\subsubsection{Injuries investigated by the Faroese Maritime Authority and the Danish Maritime Accident Investigation Board (DMAIB)}

The extent of under-reporting has not yet been studied. However, by comparing FMA reporting frequency to FAIC reporting frequency, we see that the under-reporting to FMA was very high. Additionally, the fishermen participating in the current study confirmed a $50 \%$ under-reporting of accidents. 
Faroese accidents investigated by the DMAIB, (before called Opklaringsenheden) and since 2009 taken over by the FMA, show that during 1997-2015 these accidents occur most frequently on longliners, followed by fishing boats and trawlers $\left(C_{i} T\right)$. These vessel groups account for $93 \%$ of all vessels and account for almost $2 / 3$ of the accidents.

By looking at the age of the vessels with serious accidents that have been investigated by the DMAIB, it shows that the greater portion of these accidents happened on ships older than 20 years.

\subsubsection{Statistics below from the Faroese Accident Insurance Counsel 1994-2014}

The criteria for inclusion in the study of accidents reported to the FAIC are that: The ship was part of the Faroese fishing fleet and the accident involved personal injury or damage to personal property while working. E.g. a fisherman got hit on the head by a wire and his glasses broke. Thus, not all accidents would have been mandatory to report to the FMA.

From 1994 to 2014 , longliners are the vessel group that most often reported accidents to the FAIC, followed by long distance trawlers and Group 4 a, fishing boats $15-$ 40 tons (Høvdanum et al., 2016).

\subsubsection{Accidents and age}

Accidents are evenly distributed over the age groups (Høvdanum et al., 2016). However, the age distribution of fishermen from 1994 to 2014 shows that around the age of 40, fishermen begin leaving the occupation. However, as time progresses, the proportion of fishermen over 40 years old grows larger, while at the same time, there are fewer young people entering the occupation. With the uneven age distribution, the older fishermen report relatively more accidents than younger fishermen ( $B_{i}$ Høvdanum et al., 2016). Figure 12 illustrates a significant reduction in the total number of accidents. However, when we include man-days ${ }^{1}$ at sea $(A)$, then we see that the decrease in accidents has been static for the last 10 years. ${ }^{2}$

\footnotetext{
${ }^{1} 1$ man day means each day one man has been at sea, and so if a ship with 7 men has been out for 10 days, this becomes 70 man days.

2 Fishermen's Minimum Wage Insurance Agency show the number of registered days at sea for all fishermen on vessels larger than 20 tons, or that are out at sea for more than 48 hours These are distributed according to type of fishing vessel and job title. The Faroese fisherman's union shows the number of registered salary earners in fishing apart from fishermen in Group 5 (data on these is available from 2009 onwards, The Faroe Islands Fisheries Inspection) (A).
} 
Figure 13 illustrates a significant reduction in accidents from 1994 to 2003 calculated per 100,000 man-days at sea, but when viewed in 5 year intervals, it reveals that since 2003, the accident rate has been stable with 125 accidents for each of the last two five-year periods per 100,000 man-days.

Figure 13: shows a significant reduction in accidents per 100,000 man-days at sea for fishermen from 1994 to 2012

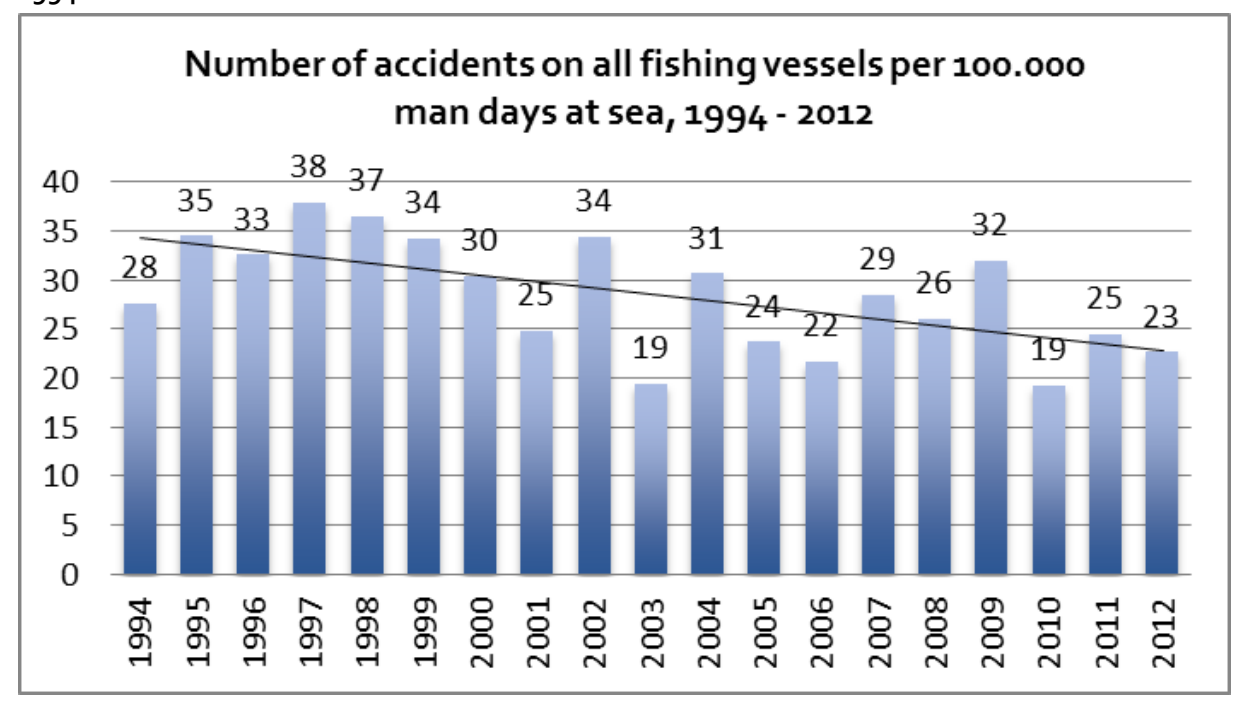

Note: The available data about the number of fishermen and days they spend at sea per annum allows for the calculation of accident trends.

Source: The Faroese Accident Insurance Counsel.

During 1994-2014, accidents on trawlers, Group 2 and longliners have reduced by about 50\%, while the number of netting vessel accidents has grown (Høvdanum et al., 2016).

Netting vessels still have the fewest accidents per 100,000 days. It is possible that as ships reach a reasonably low accident rate, it becomes harder to continue reducing and improving your statistics. 
Figure 14: Illustrates the Incidence rates per 100,000 days at sea 1994-2014 by type of vessel Incidence rates per 100,000 days at sea, 1994 to 2014 , by type of vessel

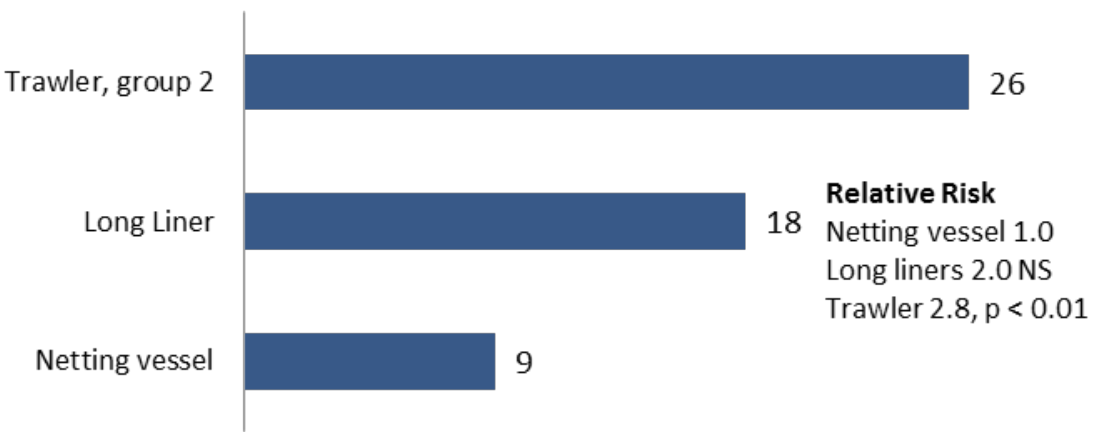

Note: Data about the number of injuries within the specific vessel types and days at sea for the specific vessel types allows for calculations of trends to compare risks between different vessel types.

Source: The Faroese Accident Insurance Counsel.

The accident risk has also been calculated from 1994 to 2014 according to job title. We see that chefs have the fewest accidents, navigators have a 1.4-times higher risk than chefs, engine crew have a risk 1.8 times more than chefs and deckhands have the highest risk of accidents, i.e. 1.9 times more than chefs. These occupational groups have respectively 11, 14, 20 and 21 accidents per 100,000 man days in fishing (Høvdanum et al., 2016).

\subsubsection{Injuries 1994-2014 sorted by mechanism of injury}

We can see that being "hit by object" is the most dominating cause of injury. It accounts for $25 \%$ of all injuries. Injuries from falls and slips come second and represent $22 \%$ of injuries (Høvdanum et al.; Mið \& Magn no. 29, 2016). Fall and slip injuries were further categorised into 4 categories: glide damage, fall not specified, falls on level and falls from height (120, 111, 83 and 42 accidents respectively). Accidents from falls and slips per 100,000 man-days have reduced by more than $50 \%$ over this period (Høvdanum et al.; Mið \& Magn no. 29, 2016). 


\subsubsection{Injured part of body 1994-2014}

Compensation for broken glasses accounts for $20 \%$ of claims. After glasses, the body parts most frequently exposed to injuries are teeth, fingers, hands, extensive parts of body, (13\%, $12 \%, 7 \%$ and $7 \%$ of accidents respectively). For more see Mið \& Magn no. 29.

\subsubsection{Type of injury 1994-2014}

With regards to type of injury (between 1994 and 2014), compensations for glasses was most frequent $21 \%$. As insurance reports were used, classification of injury was made afterwards using the categories used in the Danish accidental reporting scheme "Anmeldelse af arbejdsulykke vedrørende søfarende af fiskere", plus some extra have been added. This means it was not possible to categorise $13 \%$ of accidents. The most frequent types of injuries were: $13 \%$ injury to teeth, $13 \%$ open fractures, $8 \%$ bleedings and $5 \%$ back injuries. The rest account for less than $5 \%$ each.

\subsubsection{Place of accident}

More than half of accidents happened on deck, followed by the engine room and then the cargo compartment (Høvdanum et al., 2016).

\subsection{Strategies for accident prevention}

Several strategies have been implemented to reduce work-related fatalities and accidents. Laws that apply to Danish fishermen also apply to Faroese fishermen.

A Faroese pioneer in safety and survival training courses was the sailor school in Klaksvík (1991 - present). Safety training for fishermen has been mandatory in the Faroe Islands since 1997. The STCW-F convention for fishing vessels came into force in 2014. In June 2016, the safety training was expanded from 3 to 5 days to include material on the work environment.

A refresher course is required to be completed every five years.

There was a rapid decline in accidents per 100,000 man-days at sea from 1994 to 2002, but after this point comes a stagnation with no further reduction up to today. The decline in accidents in the beginning of the time period is expected to be due in part to the obligated safety training. However, this needs further study and it seems that additional steps are needed to further reduce the accidents. 
Each year, $0-4$ serious accidents in fisheries are investigated by the Danish Maritime Accident Investigation Board (earlier Opklaringsenhed (OE) under Søfartsstyrelsen) and since 2009 by the Faroese Maritime Authority, and in 2017 back to the DMABI. The goal is to obtain information about the causes of accidents. This is in order to make the necessary steps to reduce the risk of similar accidents happening again $\left(C_{i} T\right)$.

\subsubsection{Governmental strategies}

The Faroese Maritime Authority is the main organisation advocating safety amongst Faroese fishermen and seafarers. A primary objective is to improve safety at sea and to safeguard the rights of seamen. They are responsible for surveying ships, documentation and investigating accidents with the aim of prevention and reduction. They work in cooperation with the Faroese Fishing Inspection, which conducts partial safety checks for them.

\subsubsection{Laws and regulations}

There are several international agreements, norms, guidelines and recommendations that aim to improve safety in the fishing fleet. "The Torremolinos International Convention for the Safety of Fishing Vessels" came through IMO in 1977. Faroese fishermen are subject to all the same EU laws and regulations as Danish fishermen.

\subsubsection{Studies of safety in fisheries}

There are remarkably few studies about safety amongst fishermen in the Faroe Islands, although the fishing industry accounts for over $90 \%$ of the country's exports. From comparing an unpublished study looking at occupational accidents, reported to the FAIC in the period 1975-1979 (Weihe, Joensen and Zachariassen, 1984), and the most recent study of accident claims to FAIC in 2014 (Høvdanum, 2016), a reduction in the ratio of accidents on land and at sea is revealed, from 5:1 in 1979 to 4:1 in 2014. Two repeated job satisfaction gap-surveys have been conducted in a cooperation between the FMA and the fishermen's union, once in $2009(n=227)$, and again in 2016. In the latter, participants were fewer $(\mathrm{N}=31)$ and completed the questionnaire over the phone.

The gap-survey indicates that safety is not optimal on board Faroese ships, but concludes that some gaps from the first study were not a problem in the second study, indicating significant improvements and an attitude change. 
Because of limited studies and evaluation of safety programmes in the Faroese fishing fleet, it is difficult to offer information on the casual factors for the reduction in accidents, other than safety training being expected to account for a significant decrease in the accident rate.

There is a need to continue with the safety programmes and monitoring of injuries to learn from the past. More studies on evaluating what factors contribute to a reduced accident rate is required.

Based on the authors' own study of accident claims of fishermen from the data register of the FAIC 1997-2014, a conference about safety in fisheries was held in August 2016, for fishermen and other interested parties. Furthermore, informative pamphlets were printed and a short film about safety was produced (Høvdanum, J. (Producer). (2016). Trygd á sjónum. [Cartoon movie]. Faroe Islands: Eat Willy Productions. These were summarising the main risks and dangers on board Faroese fishing ships and the frequency of how and where most accidents happened, as well as including frequency tables stating the kind of injuries and the most frequently injured parts of the body. Finally, it offered preventive advice $\left(G ; H_{i} l ; J\right)$.

A review of accidents investigated by the DMAIB in fishing from 1997 to 2014 indicates that although serious accidents had reduced, (with no accidents from 20002007), they are now back at the same rate as in $1997\left(C_{i} T\right)$. The reason for this requires further investigation.

\subsection{Summary}

The number of fishermen has fallen drastically over recent years, as there are fewer young people entering the fishing occupation, as well as some leaving it. With fewer people in the occupation, the total number of accidents has also fallen significantly. Calculated per man-days, the accident rate has fallen significantly in the period from 1994 to 2002. Thereafter it has been stable, with a mean of 25 incidents per year, per 100,000 man-days at sea for each 5 -year period. The reason for this stagnation needs further investigation, but it seems that the safety activities in use are not enough.

Very little research has been conducted about safety amongst fishermen in the Faroe Islands. The psychosocial work environment first became part of the safety course in June 2016.

The accident rate varies between the different vessel types, with netting vessels having the lowest accident rate and deep sea trawlers, Group 2, the highest. 
The most frequent accident mechanism is being hit by an object (24\%), followed by falls and slips (22\%). Glasses account for about $20 \%$ of all the accidents since 2000 . After this, the most frequent injuries are to teeth and fingers, or injury to more than one part of the body. The most frequent types of injury are teeth injuries and closed fractures. Most accidents happen between $2 \mathrm{pm}$ and $4 \mathrm{pm}$. The Faroe Islands have the same laws and regulations as Denmark, but do not have a function comparable to the Fishermen's Occupational Health Service (FA), which holds the function of advising and consulting with fishermen regarding safety.

Figure 15: Two purse seiners work together. Avoiding accidents requires synchronization between the crews of both vessels

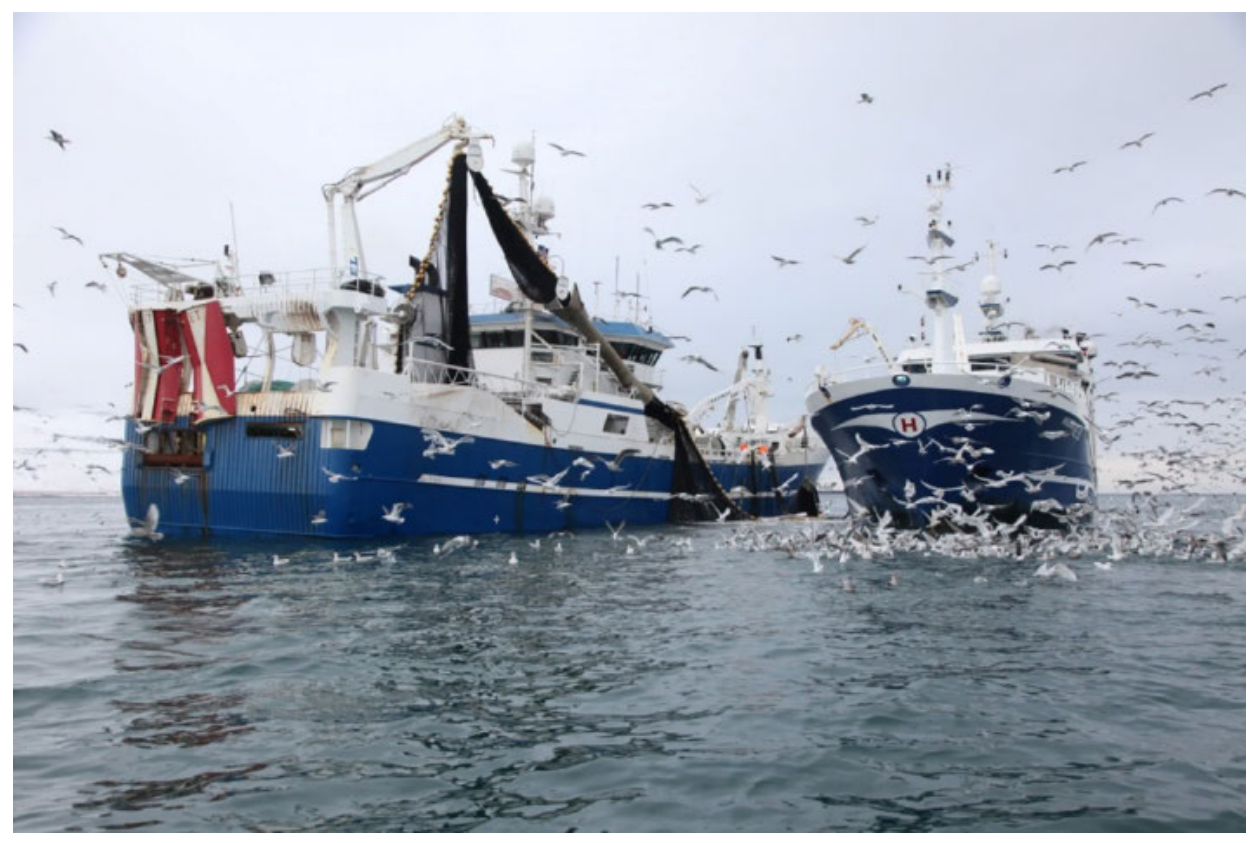

Photo: Thorgeir Baldursson. 
Figure 16: Fishing is dangerous but proper gear can enhance the safety of fishers. However, situation awareness is needed at all time

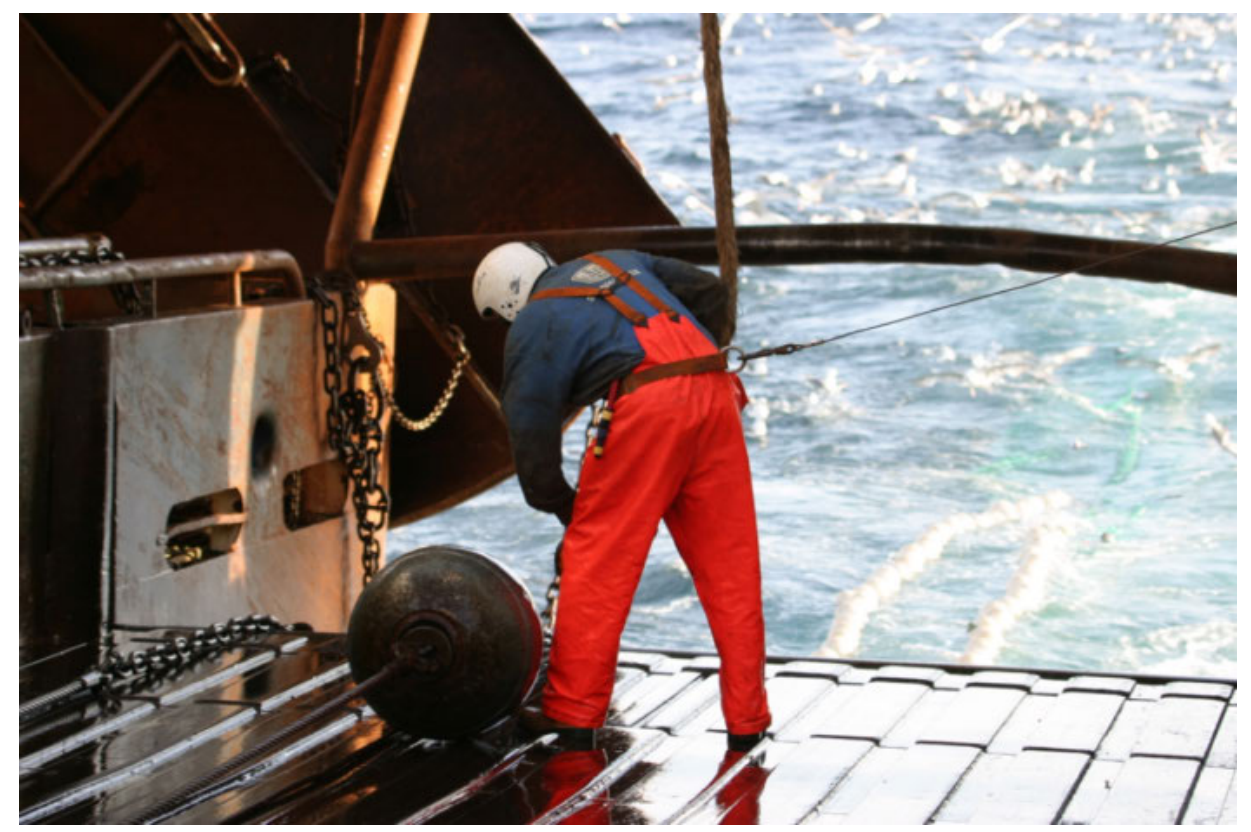

Source: Thorgeir Baldursson. 


\section{Iceland: Occupational accidents and safety work in the Icelandic fishery-Developments and pre- ventive measures}

Authors: Hilmar Snorrason and Kristinn Tómasson

\subsection{Safety training}

In 1984, a Parliament-appointed committee on safety at sea reported their findings and recommendations on how to improve safety amongst Icelandic seafarers and fishermen to the Ministry of Transportation, which at that time was responsible for issues relating to safety at sea $(L)$.

The years since the end of WWII had shown a huge loss of life amongst Icelandic seafarers and fishermen, with up to 59 lives lost in the year 1959. From 1946 to 1984 , an average of 21 persons got lost at sea per year. The committee had been established the year before and its members were nine Members of Parliament from all the political parties that formed the Parliament. 17 proposals were issued by the committee in 1984, but in 1986, 20 proposals were put forward, but some of them were also included in the 1984 recommendation. The third recommendation in the 1984 report was to establish safety training for Icelandic fishermen and seafarers. Later that year, a Safety Seminar was held in Reykjavik, where it was decided to ask the National Life-Saving Association of Iceland (NLAl) to establish safety training. In May 1985, the Maritime Safety and Survival Training Centre (MSSTC), newly formed by the NLAl, held its first Basic sea survival, firefighting and safety course. In the first year of operation, only a few participants attended the courses, as many of the fishermen didn't think they needed the training because they knew all that was needed in this field.

NLAl is a nationwide Association, consisting of volunteers with rescue teams in every port around Iceland, as well as having a women's league that was supporting the rescuers. Many of those women were married to fishermen or seafarers, or were widows. With the 
help of this women's league, MSSTC managed to get the message to the fishermen about the importance of having better knowledge in establishing a safety culture on their ships, and how to use the equipment that was a mystery to them. In those days, few or no safety drills took place on board the fishing vessels. Slowly, the number of course attendees started to grow, but it was clear that more needed to be done to get the fishermen to the courses. In the first five years of operation, the number of fatalities started to reduce, which was believed to be one of the results of the training.

In 1991, a motion for legislation was put forward in the Parliament in the name of all political parties. Among other articles in the motion, about the MSSTC there was that safety training should be mandatory for allowing any person to go to sea. The motion was accepted (M) in the Parliament and soon the first legislation about mandatory safety training came into force. That was in 1998, but a sanction had to be given for some years in order to allow the fishermen to fulfil the new requirements.

\subsection{Fatal accidents}

A fatal accident involves an accident where death is immediate or directly follows from the consequences of the injuries received in the accident. The information on fatalities is obtained from the Icelandic Transportation Safety Board, from the section handling accidents at seas and its predecessor (K). From 1984 to 1997 , the average number of fatalities at sea dropped from 21 per annum to 9 per annum. These significant numbers showed that some changes had been made in the industry. There were definitely a few factors that had led to these changes being so positive, but the safety culture was changing and that was undoubtedly due to better knowledge following safety training. Following this result the Ministry of Transportation issued a regulation in 2003 that required all seafarers and fishermen to attend refresher courses in basic sea survival and firefighting at no less than five-year intervals. The courage of the Parliament and the Ministry of Transportation to act as per the recommendation given by the Safety committee, and the results shown in the number of fatalities, has meant that requiring mandatory safety training should be embraced.

Figure 17. The pie chart shows the causes of fatality among Icelandic seafarers since the establishment of safety training in Iceland. 


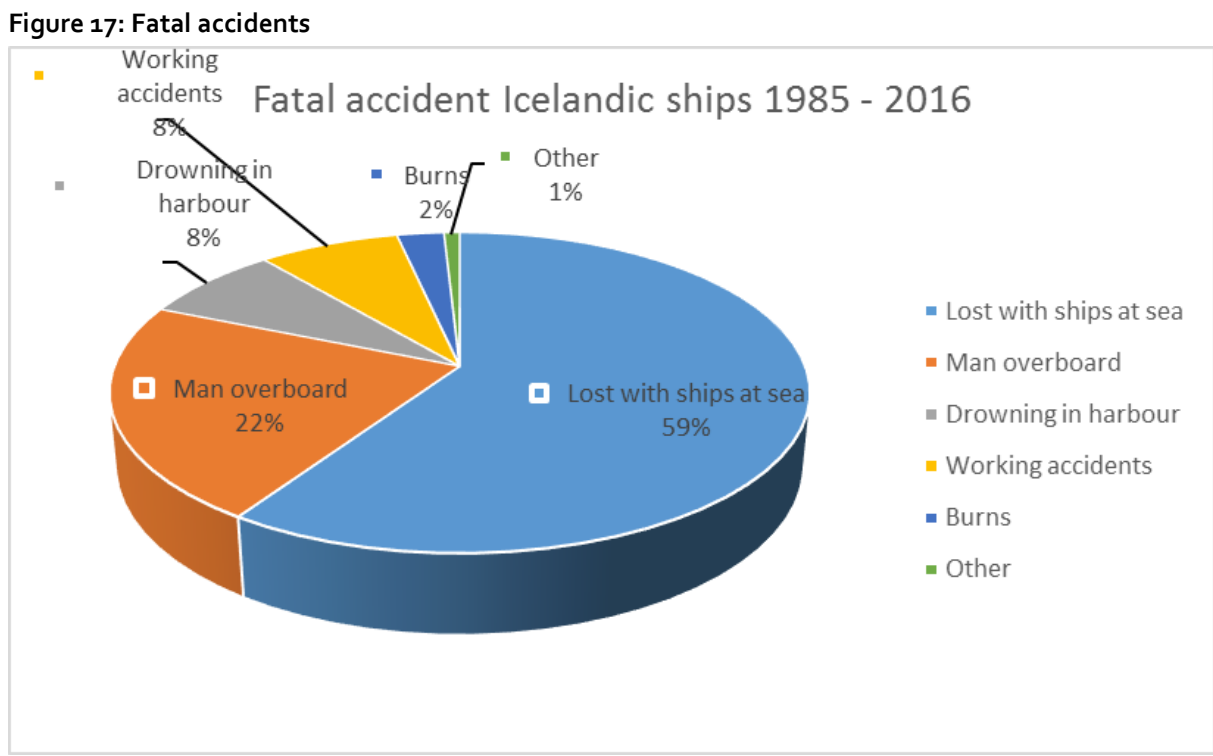

Source: Icelandic Transportation Safety Board, section handling accidents at sea and its predecessor.

To give an indication how the situation was before and after the establishment of safety training and implementing mandatory safety training in 1997, and again in 2003 with refresher training, the following graph shows the number of fatalities per annum from 1971 to the present day. 
Figure 18: The number of fatalities per annum from 1971 to 2016

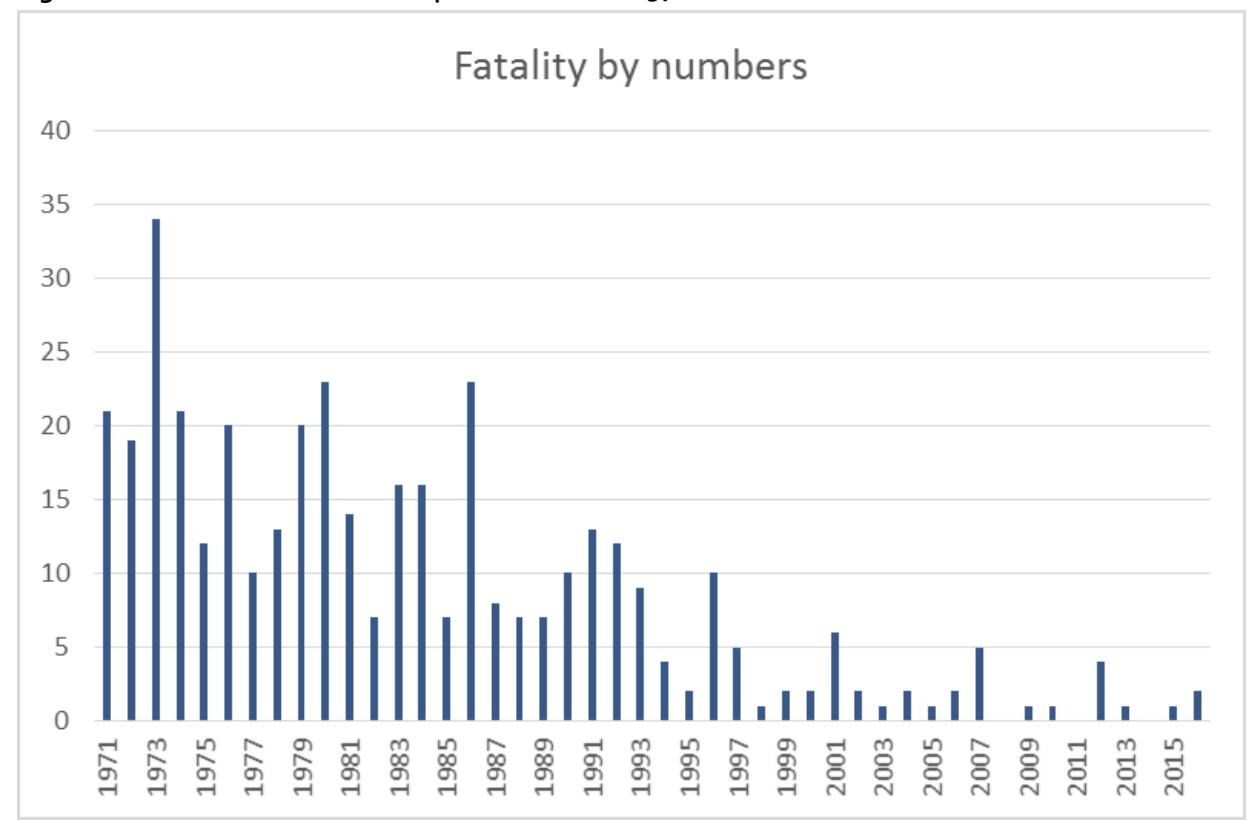

Source: Icelandic Transportation Safety Board, section handling accidents at sea and its predecessor

The exact number of workers at sea cannot be found at Statistics Iceland as seamen have been categorised with farmers. On the other hand, all workers at sea on ships flying the Icelandic flag must register every time they are signed for onboard duties, no matter whether the person is only registered for one day or for the whole year. The small fishing vessel fleet (boats from 6 to 15 metres in length) did not join this registration system until the law was changed in 2011 . The number of fishermen has therefore been estimated based on that and in the following calculation regarding the number of fatalities per 100,000 workers. 


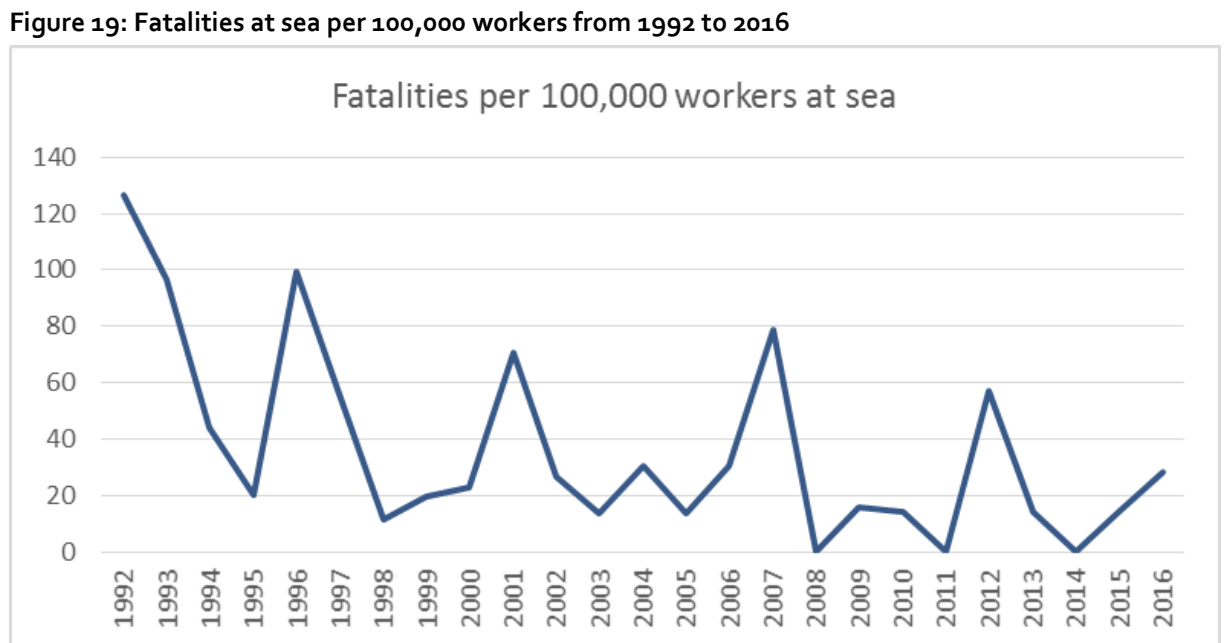

Source: Icelandic Transportation Safety Board, section handling accidents at sea and its predecessor

\subsection{Accidents}

In 1986, new legislation for seafarers' rights was accepted by the Parliament and this strengthened the right for compensation due to sickness or accident. In the Act, it says that a crewmember who is unable to work due to sickness or injuries shall not miss any of his salary in any way if he cannot work due to the mentioned causes, but for no longer than two months. If he has been working for the same ship or the same operator for more than two years, he shall have in addition basic salary for one extra month. To be accepted for compensation, an accident must be reported to the Icelandic Health Insurance (IHI). This seafarers' right is very important and also urges the reporting of both minor and major accidents. Through the years, the MSSTC has encouraged all seafarers and fishermen participating in safety courses to report all accidents, no matter the seriousness of them, as later symptoms can show up that could be related to the incident. The chart below shows the number of accidents reported to the IHI from 1992 to 2015 . In this, the accidents are defined as injuries resulting in a loss of work time at sea. 
Figure 20: The number of accidents reported to the IHI from 1992 to 2015

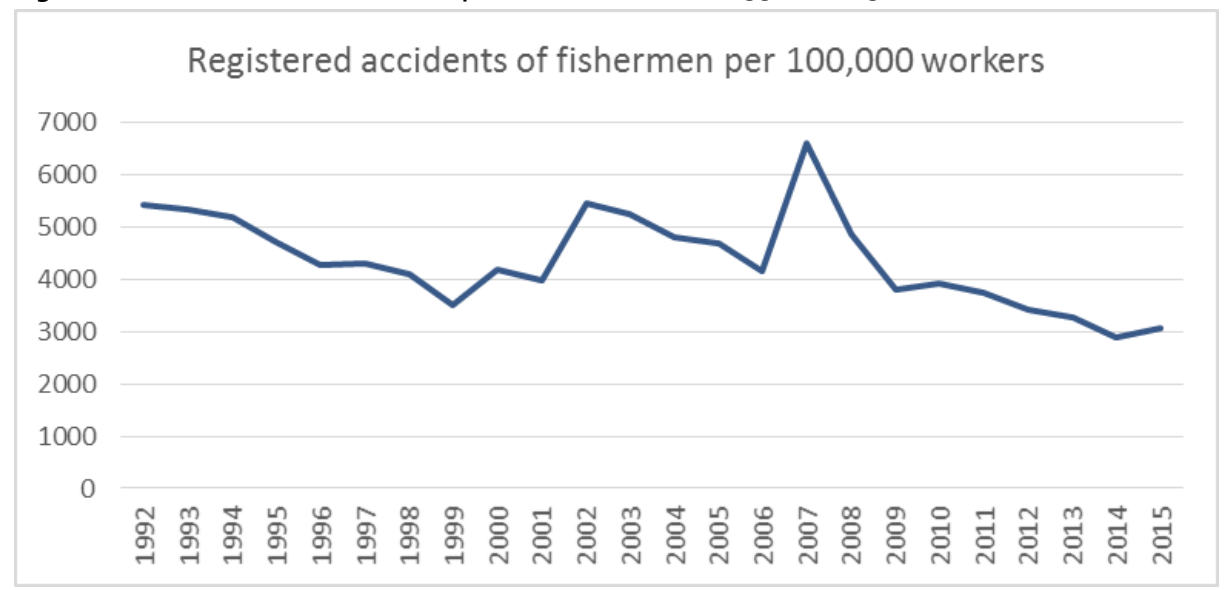

Source: The Icelandic Health Insurance.

The numbers show that there has been a reduction in reports, but they do not show the seriousness of the accidents. They only indicate the year of the report, but the accident could have happened before that year. In addition to the obligation to report accidents to the IHI, it is also mandatory to report all accidents to the Icelandic Transportation Investigation Board. Despite the legislation, only about $25 \%$ of accidents are reported to the Investigation Board, and usually the most serious ones. It is noted that for the last 20 years, a significant reduction of serious accidents have been recorded. The most common accidents on Icelandic ships can be seen on the pie chart below. 
Figure 21: The most common accidents on Icelandic ships in the past 20 years

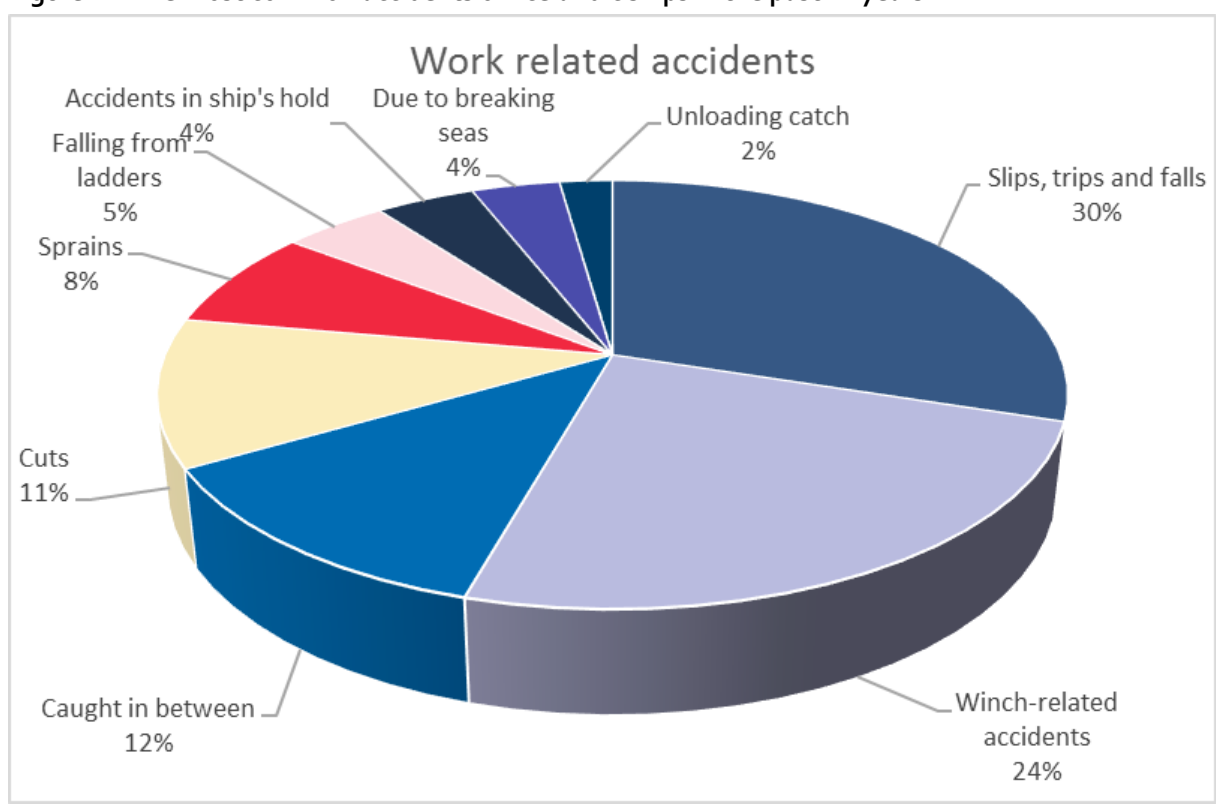

Source: Icelandic Transportation Investigation Board.

By analysing the accidents, it can be clearly seen that there are peak hours regarding work-related accidents on Icelandic ships, which are between 10 and 11 in the morning and from 14 to 15 in the afternoon (see graph). An explanation for that is not known, but there are lots of speculations. The watch system has often been criticised, but there are several systems in use. On the bigger fishing vessels, officers are usually on 12/12 watch systems, while the crew is on $6 / 6$. Recently the $6 / 6$ watch system has been overtaken by an $8 / 8$ system on many ships. On the smaller fishing vessels, there are $16 / 8$ and $18 / 6$ systems. No study has been done on the different watch systems on Icelandic ships, but fatigue has been taken into consideration more and more regarding worldwide accident causes. 
Figure 22: Time of accident aboard Icelandic fishing ships

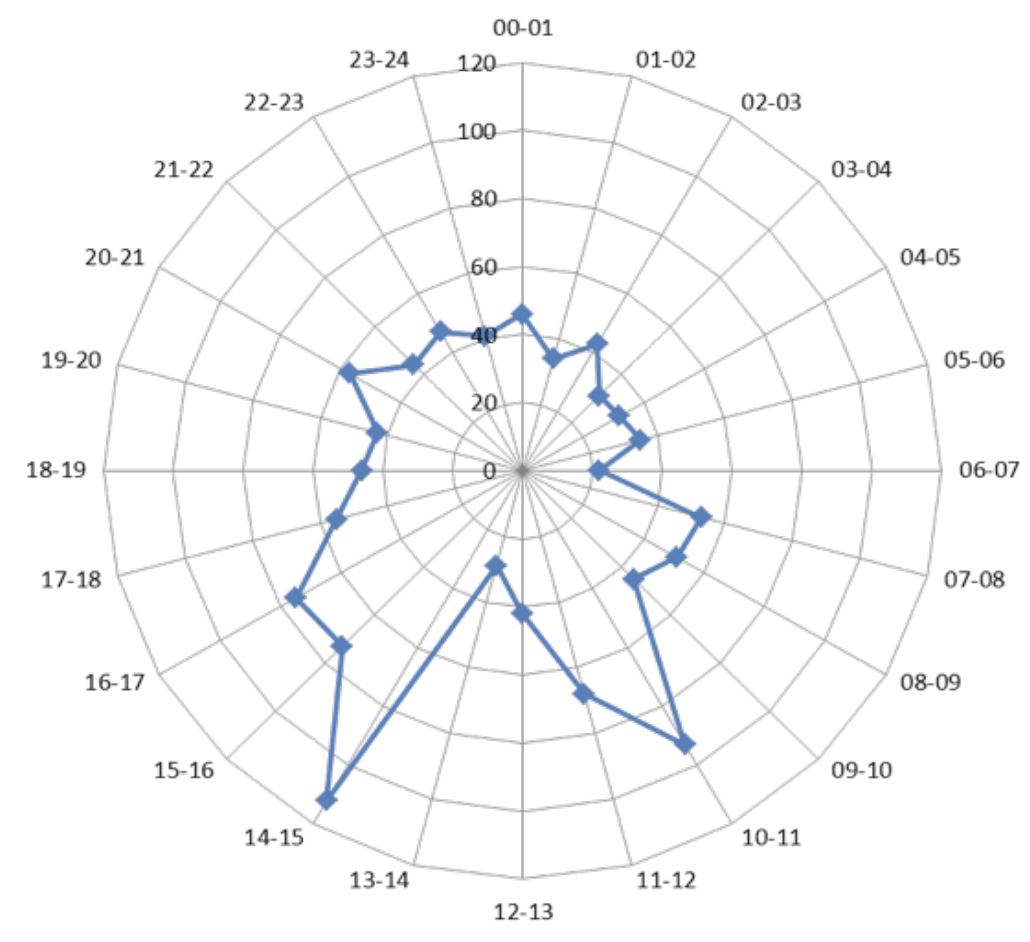

Source: Icelandic Transportation Investigation Board.

\subsubsection{Way ahead}

The significant reduction of accidents on Icelandic fishing vessels can be credited to the better safety awareness of Icelandic fishermen. Safety training plays a big role here. But other things have also changed. Better weather forecasts and weather-related information to fishermen have shown that fishermen can return to port before bad weather hits them, or not to leave port if foul weather is ahead. The Icelandic Ships Monitoring System plays an important role in the safety surveillance of the seafarers. The Icelandic Coast Guard, through the AIS system, keeps constant surveillance of all Icelandic ships in territorial waters, and if a vessel disappears from the system, rescue units are alerted and sent to the last location of the fishing vessel. This surveillance and response have saved several lives of fishermen in distress at sea. Ships are also getting better with every new generation of fishing vessels, but on the other hand, a reduction in crew size has happened at the same time. Fatigue is therefore a great concern for the industry. 
Despite all of the above, it is clear that the attitude of Icelandic fishermen towards safety culture has changed dramatically in the last 30 years.

\subsection{Summary}

The fishing industry is one of the pillars of the Icelandic economy. The safety of the fishermen is and needs to be a cornerstone in the development of the industry. Good and safe vessels are crucial for this to be the case. The training and repeated safety training of the crew are fundamental to achieving the goal of zero accidents. The trend has been favourable in the direction of fewer fatalities and fewer injuries, but the data also clearly show that improvements are still needed. These improvements need to involve all aspects of the fishermen's work environment and the management of it. But it remains striking that among the few studies published, the following conclusion is made (Sigvaldason K, 2010) "Fatalities have declined steadily in the last two decades, yet $7 \%$ of registered fishermen sustain injuries each year. These occur amongst experienced fishermen in good external conditions, which calls for a revision of safety procedures on board".

Figuree 23: The fisher's attitude towards safety is shown in the statistics of accidents and fatalities in the industry

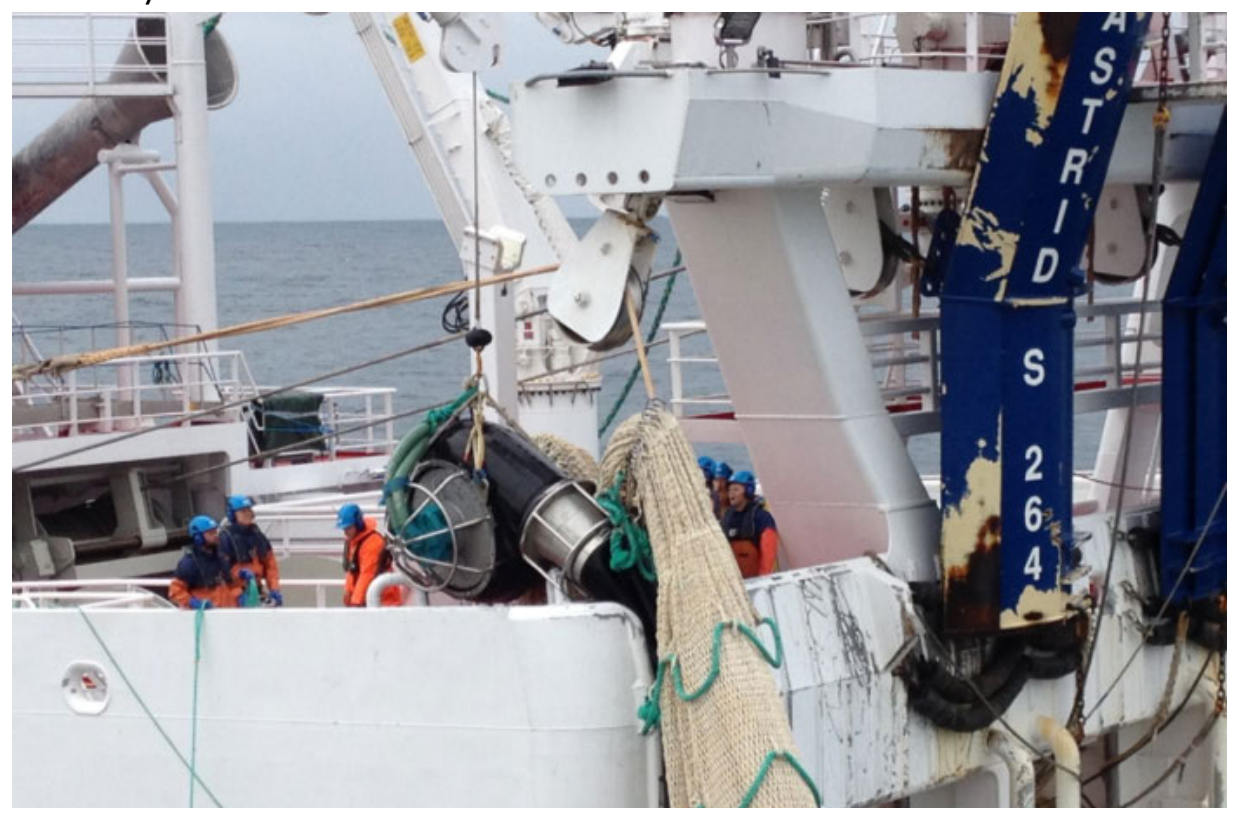

Source: Thorgeir Baldurssson. 


\section{Denmark: Occupational accidents and safety work in the Danish fishery - Developments and pre- ventive measures}

Authors: Jørgen Møller Christiansen and Helle Østergaard, Centre for Maritime Health and Society (CMSS), University of Southern Denmark.

\subsection{Introduction}

In 1988, the first comprehensive study of occupational safety and health in the Danish fishing and merchant navy was completed (Jepsen and Christiansen, 1988). This study showed that there was a great need for substantial improvement of the work environment and health care of seafarers, fishermen and employees on oil rigs. This study identified five key recommendations:

1. Occupational health and safety organisations at sea.

2. Centralised and updated Radio Medical advice for seafarers and training of heath care providers on board.

3. Establishment of training regarding work environment and safety at sea.

4. Establishment of a maritime medical research institution.

5. Establishment of an occupational health service council for the maritime industries.

In the years that followed, all five recommendations where implemented. In 1988, all maritime administration was combined with the establishment of the Danish Maritime Authority (DMA). In the 1990s, occupational health services were established for the merchant navy (Seahealth) and for fisheries (called Danish Fishermen's Occupational Health Service). Radio Medical Denmark and a maritime research institute (now the Centre of Maritime Health and Society) was established in Esbjerg. Health and safety 
training became mandatory by law. In the fishing area it became a requirement that all new fishermen complete a three-week safety course before they can start their fishing education.

During recent years, there has been significant attention towards the developments regarding occupational accidents. In the late 1990s, the primary focus in the fishery was serious accidents (Søfartsstyrelsen, 1998), and under-reporting of accidents was significant (Jensen, 1996). A campaign was launched in order to promote notification of all statutory occupational accidents. In 1999, the number of reported accidents was 200, out of which almost half were reported as slip and fall accidents (Fiskeriets Arbejdsmiljøråd, 2000). In converted form, 200 reported accidents correspond to 28.5 accidents per 1,000 fishermen. The number increased until 2000, where reported accidents were approximately 53 accidents per 1,000 fishermen (Christiansen and Østergaard, 2016). Since then, the number of reported accidents has almost evenly decreased (see Figure 24) with the lowest level being reached in the latest statement from 2014 (11.5 reported accidents per 1,000 fishermen).

Figure 24: Incidents. Notified occupational accidents per 1,000 employees/fishermen

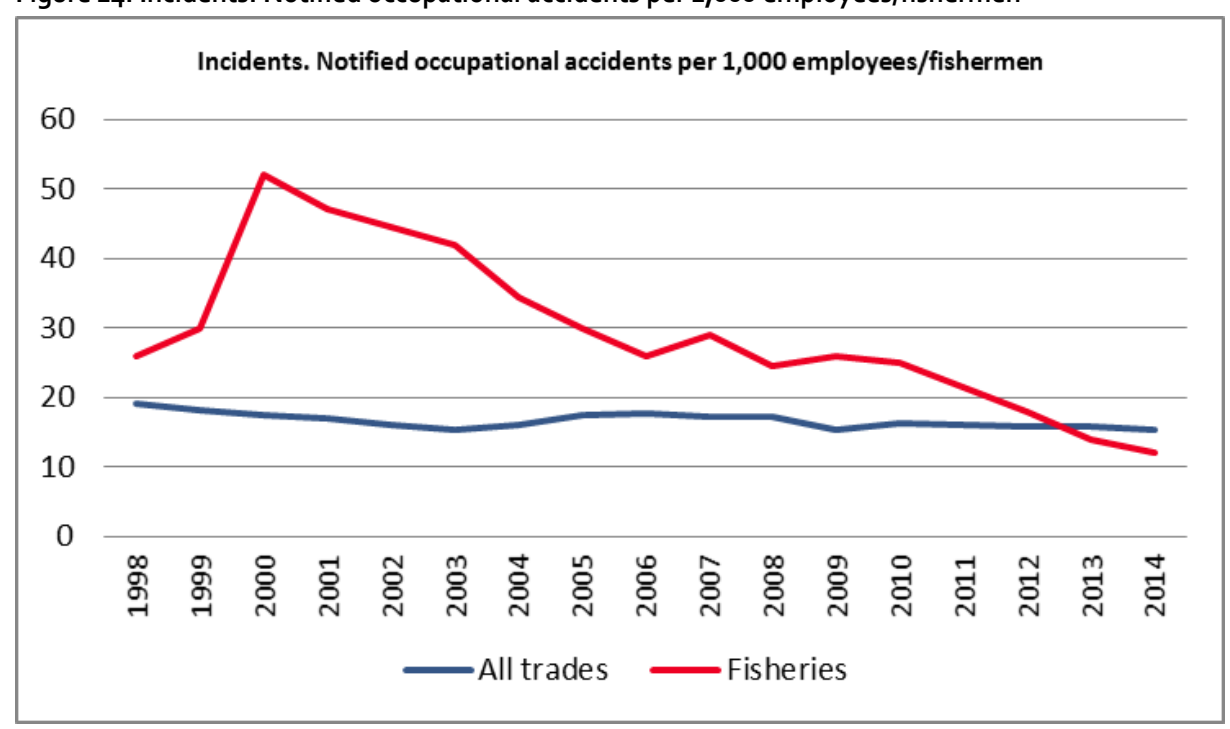

Note: Fisheries: Reported accidents to the Danish Maritime Authority.

Source: All trades: Reported occupational accidents. Annual statement. The Danish Working Environment Service.

As shown in Figure 24, the occurrence of accidents in fisheries was earlier at a high level, but since 2013 the rate has developed to be now slightly below the level of all trades. 
The positive developments regarding occupational injuries in the fishing fleet is also reflected in the development of the premium for workers' compensation. The premium has decreased by $37 \%$ in 2014, and in 2015 the Danish fishermen's insurance company has further reduced the premium by $11 \%$. The number of fishermen has reduced in the period, and this has been a contributing factor to the reduction in the insurance premium.

\subsection{Preventive measures in the work environment}

The rules in the fishery regarding the statutory notifications of accidents is the same as on land, which means that any accident resulting in at least one day of incapacity should be notified. A similar but less dramatic decrease in occupational accidents has been observed for land-based trades. From 2005-2014 there was a decrease of $14 \%$. On the other hand, there have not been any significant changes if we look at a longer period of time (Arbejdstilsynet, 2016, p. 14). ${ }^{3}$ In the same period, 2005-2014, the fishery has experienced a decrease of approximately $60 \%$. The performance of a safe and healthy work environment in the fishery is parallel to what is applicable on land. The decreasing trend had a somewhat late start in the fishery and lagged slightly behind the development on land. However, there are some differences. In the fishery, completion of a safety course is required before entering the fishing school and achieving the blue certificate, which is required for working as a fisherman. ${ }^{4}$ Furthermore, the fishery has maintained an occupational health service, ${ }^{5}$ The Danish Fishermen's Occupational Health Service (FA), which provides services to fishermen. The procedure and case management regarding work-related accidents aims to prevent accidents, so that the risk of accidents in the future is minimised. An illustration of the procedure is presented below.

\footnotetext{
3 In the Danish Working Environment Authority's report from May 2016: About accidents and prevention, has the incidence of reported accidents calculated, i.e. all accidents per 10,000 employees. The report concludes "Both in terms of all reported accidents and reported serious accidents, there is no change over a longer period. There are variations from year to year, but it does not mean changes in accident occurrence when a number of factors affect the degree review. However, it is striking that the development in the rate of fatal accidents is markedly different. There has been a steady and significant decline primarily since the mid-1990s, since when the number of fatal accidents has been halved."

4. The rules apply unless he or she can show at least 2 years of employment with fishing within the last 5 years prior to September 1 st 1996.

5 The statutory BST agreement was founded on land in 1977 and discontinued in 2003, when the voluntary authorised health and safety council replaced it.
} 
Figure 25: Procedure for managing accidents

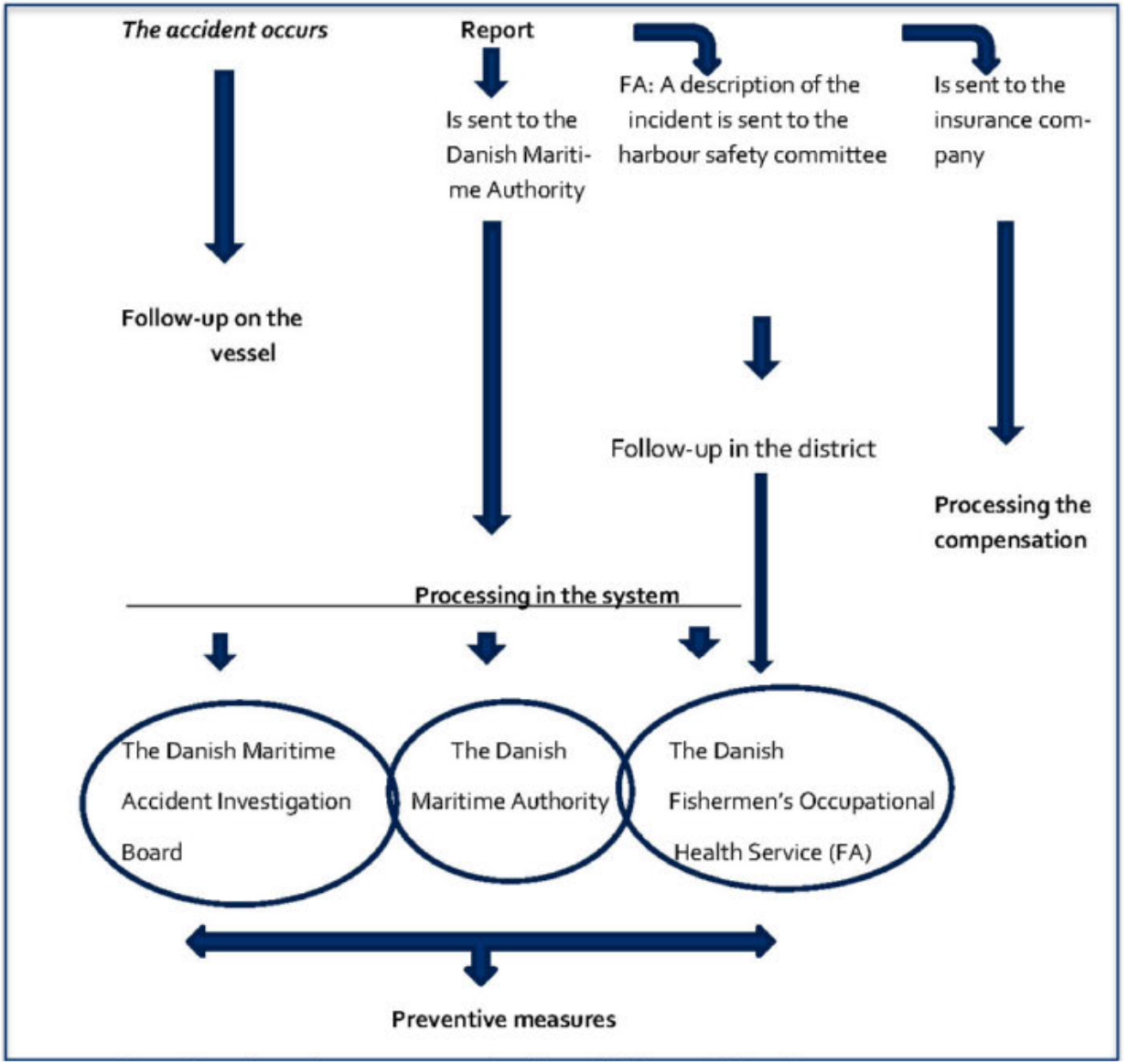

Source: Procedure and case management of accidents. Christiansen, J.M.(2016).

When an accident occurs, the report is sent to the Danish Maritime Authority (DMA). The follow-up takes place in several different ways: on the vessel, in the administrative system and in the local harbour safety committees. These institutions will be presented in the following.

\subsubsection{The Danish Maritime Accident Investigation Board}

The Danish Maritime Accident Investigation Board investigates maritime and work-related accidents that have taken place in Danish and Greenlandic vessels, both in mer- 
chant shipping and in fishery. Accidents happening on foreign ships are also investigated when they happen in Danish or Greenlandic territorial waters. The aim is to clarify the circumstances of the accidents and to promote initiatives that will increase safety at sea. In the event of a maritime disaster or a serious work accident, the Board will complete a thorough report, which will be published on their homepage.

\subsubsection{The Danish Maritime Authority}

The Danish Maritime Authority (DMA) is the overall responsible authority, which deals in particular with regulation and control of the maritime work environment, and regular control and guidance is undertaken to assess that vessels comply with the applicable legislation. The check is based on vessel's self-regulation. There are some preconditions for allowing the vessels' crews to perform the checks themselves. For example, no technical or operational errors should be identified on the ship in the previous investigation. Moreover, it is a condition that no work or sea accident has occurred on the vessel during the period from the latest self-regulation to the next. On fishing vessels below 15 metres, it is mandatory to hold an annual self-inspection and a specific checklist is used. Larger vessels use an extensive scheme when making the control.

In addition to control and guidance about safety on board, the more recent initiatives regarding the work environment made by the DMA have focused on vessel stability, with particular attention on fishing vessels, which occasionally engage in industrial fishery, compliance with safety requirements regarding the cleaning machines, and the risk when releasing and taking in the fishing gear.

An important tool when working with safety on board is the Announcement from the DMA, a "Technical regulation on occupational health on ships", which contains the requirement for the vessel to prepare a workplace assessment (in Danish: APV) that must be revised at least every three years. The skipper carries the responsibility for elaboration of the APV and also carries the responsibility to ensure that the APV is implemented in cooperation with the entire crew. By working with the APV, any tasks that may affect the safety and health of the crew will be discussed and reviewed. It is mandatory to elaborate a written risk assessment, which includes a plan for action, when a work task is considered to constitute a "particular risk" for the crew. When a new crewmember enters the ship, the skipper and the new fisherman must have a dialogue about work tasks on board that represent particular risks regarding safety and health.

Reviews of accidents are sent to the DMA, where they are assessed, and guidelines will be released when particular risks of accidents at work are noticed, as mentioned above. Accident reports will furthermore be forwarded to the Fishermen's Occupational Health Service, where a follow-up also takes place. 
Figure 26: Tasks are assessed and APV, workplace risk assessment are described in jointly in a Danish fishing boat

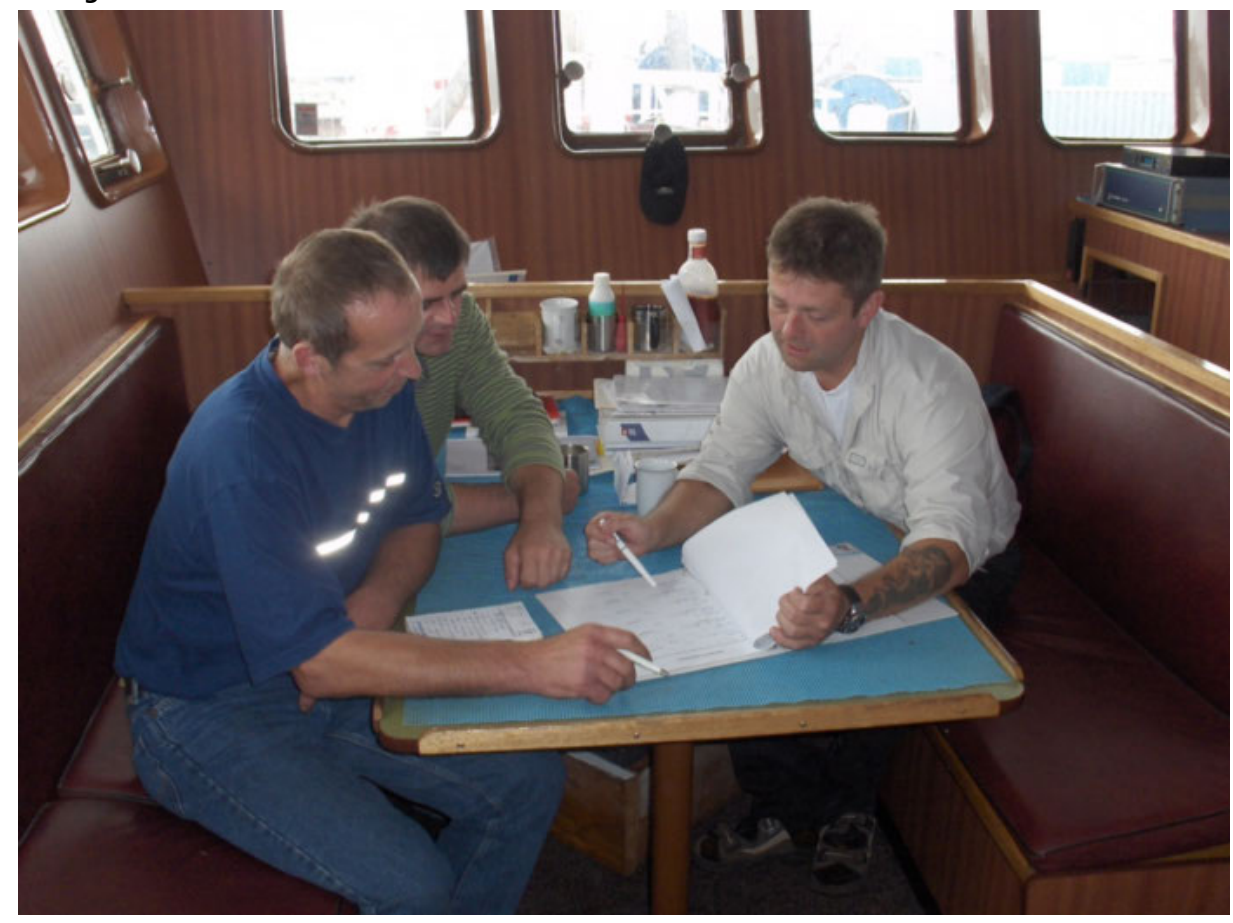

Photo: Fiskeriets Arbejdsmiljøråd

\subsubsection{The Danish Fishermen's Occupational Health Service}

The Danish Fishermen's Occupational Health Service (FA) was established in 1993 (O). A bipartite board (employees and shipowners) leads the FA, which provides service to all Danish fishing harbours in the Danish Realm - however, in practice, predominantly in Denmark.

The purpose of the FA is:

- Promotion of safety of the fishermen

- Prevention of occupational injuries

- Maintenance of a healthy and safe work environment 
The tasks include:

- Identification and evaluation of health and safety issues in fisheries.

- Provision of information and guidance.

- Coordination of the work of the local harbour safety committees (HSU).

The Harbour Safety Committee (HSU) constitutes the vessels' safety committees. The Danish fishing industry consists of a large number of smaller ships, each of which has only a few crew-members. The HSU is established in fishing ports along the East, North and West coasts of Denmark. In addition, independent safety committees are established on the larger ships. The committee consists of employees and shipowners. The tasks of the HSUs are to:

- Plan, manage and coordinate safety and health work.

- Investigate the causes of:

- Accidents.

- Poisonings.

- Work-related disorders.

- Prevent recurrences.

The members of the HSUs are obligated to participate in an approved occupational health course of 32 hours duration.

The issuance of executive orders regarding the establishment of the FA in the beginning, back in 1993, was met with discontent by the fishermen. The fishermen had a payment imposed of a total of 500 Danish crowns excl. VAT per person on board per annum on each fishing vessel that possessed a registration number. The payment included the establishment and operation of the council, service and the local harbour safety committee. The fishermen saw it as yet another intervention in their lives and yet another way to collect taxes. However, the resistance faded as the fishermen got a better understanding of the relevance of the work environment to the crew's health and safety and thereby realised why the service was useful (Christiansen and Østergaard, 2016). 
Throughout the years, the FA has launched a lot of different initiatives and activities, which in aggregate form includes:

- Guidance, help and support to the fishermen. Over the years, the FA has continuously been in dialogue with the fishermen about practical issues regarding health and safety on the vessels. Among other things, these consultations take place through quarterly meetings with the HSU (more later).

- Teaching on the fishing schools, creating educational and information materials, and elaboration of electronic information materials. Initiatives and campaigns focused on known risks in the work environment, for example the stability of the vessel, icing, rescue equipment, lifting equipment, work in the hold, slip/fall accidents, etc. In 2015/16, the FA launched a campaign aimed at ergonomics and lifting injuries. This campaign was based on a "road show", consisting of a container in which there is installed ergonomically-correct lifting gear, so that fishermen can try them and learn good lifting techniques. In 2014-2015, the FA released seven DVD movies that focus on safety work, safety culture and safe behaviour in connection with performance when working on fishing vessels. These movies illustrate the fishermen's own narratives regarding their daily work at sea. The fishermen are followed in work situations on board when fishing with nets, trawls, fly fishing, Danish seiners, seiners and beam trawling when fishing for mussels and shrimps. Two of the films deal with the prevention of hydrogen sulphide in the cargo if the fishing boat and the use of APV in the safety work on board, respectively. This emphasises the good examples, solutions and attitudes towards safety. In the past year, the DVD movies have provisionally been watched up to 8,600 times.

- Preparation and conduct of a risk assessment tool - "Safety management system" for the vessels. In this web-based program the fishermen can perform the statutory workplace evaluations, describe near-miss accidents, keep track of the vessel's medicine supply, and more. The system is the only one of its kind in the world and therefore unique. Fishermen in Denmark, Greenland and Scotland use it.

\subsubsection{The Harbour Safety Committee (HSU) and accidents}

As mentioned, safety work in the fishery is organised in the fishing harbours and on the big fishing vessels. The HSU handles instances of workplace accidents. The DMA sends a copy of reported accidents to the FA, which forwards the report to the HSU. At quarterly meetings, the FA and the HSU discuss the accidents. If the HSU have no 
knowledge about whether or not there has been a follow-up regarding the accident on a certain vessel, they will send a notification to the vessel with a request for a review of what has happened. In this way, continuous attention and dialogue about accidents, and also about preventive initiatives, have been achieved.

\subsubsection{Studies of accidents in the fishing fleet}

Several studies of accidents in the fishery have been made, as hereinafter will be described chronologically.

The following is a summary of an article that was prepared in connection with this project (Christiansen and Østergaard, 2016).

\subsubsection{Theme investigations of serious accidents}

In 2006, the Maritime Authority's Investigation Division ${ }^{6}$ made a thematic study covering the period 1998-2005, where 28 serious accidents that had happened in Danish fishing vessels were analysed in order to identify risk factors in the fishery. The accidents occurred when handling winches and/or equipment that led to bodily injuries or fatalities.

The study found that the majority of these accidents occurred on trawlers, especially large trawlers with a length over 24 metres. Slightly less than half of the serious accidents occurred when working with net drums on the front deck or quarter-deck, or by working immediately beside the net drums. Other accidents were more isolated, and for instance related to work with trawl blades, block pulleys or when hit by a trawl wire, distance line, anchor gear or seine. In a number of the cases, the victim had had less than 6 months experience on the ship when the accident occurred (Opklaringsenheden, 2006).

The safety culture was only modestly articulated at the time, which can partly be illustrated by the fact that only six out of the 28 vessels had prepared the statutory risk assessment.

Furthermore, the study showed that poor weather conditions were not the main factor, and that alcohol was not a contributing factor to the accident in any of the 28 cases.

In relation to this project, we made a study where we analysed the Danish Accident Investigation Board's submissions of serious accidents at work in the fishery from 19992013. It includes 46 reports, which are available on their homepage.

\footnotetext{
${ }^{6}$ The Investigation Division of the Danish Maritime Authority was abolished in 2011 and replaced by an independent institution, the Danish Maritime Accident Investigation Board, and its scope is determined in Law no. 457 from May 18 th $2011-$ Law about safety investigation of marine accidents $(P)$.
} 
The analysis indicated that the serious accidents happened especially in connection with falls overboard, putting out and taking in the fishing gear, and operation with the fishing gear. The reports illustrate that three-quarters of all serious accidents occurred on trawlers. In converted form, it is approximately 6 times more often than would be expected when looking at the trawler fleet's proportion of the total fishing fleet in Denmark. The reports also suggest that the observed decline of the number of serious accidents is mainly due to the modernisation of the fishing fleet and a reduced number of typically older vessels of wooden construction.

The serious accidents occurred on vessels with a mean crew-size of 3.7 fishermen, all of which worked on significantly larger vessels than the average of the Danish fishing vessels, in which the mean crew-size was 1.3 fishermen in 2013 (Christiansen and Østergaard, 2016).

The reports made by the Danish Accident Investigation Board contain examples that illustrate that a safe work environment was not taken into account in relation to the construction of the gear and the machines that the fishermen worked with.

The reports show what the Investigation Division also identified (see above), which is that a significant part of the serious accidents happens under good or reasonably good weather conditions, and that some of the serious accidents affected fishermen who had recently joined a new vessel or had started as apprentices in the fishery.

\subsubsection{Safety culture}

The latest study of accidents in the fishing industry consists of an analysis of work-related accidents and includes eight individual interviews and one focus group interview with fishermen. This study indicates that there have been changes in fishermen's behaviour regarding safety. Now safety has become a priority on board and altogether this attention seems to have led to an improved safety climate and safety culture (Grøn et al., 2014).

\subsection{Analysis of reported accidents from 2000-2015}

In addition to the Nordic project, an analysis of all reported accidents in the Danish fishing industry from 1997-2015 has been conducted (Christiansen and Pedersen, 2016). This analysis shows that the findings from the two earlier studies of serious accidents described above are repeated. This analysis also shows that work-related accidents occurred far more frequently during fishing off the West coast of Denmark. There is a significant over-representation of accidents in the trawler fleet, and new employees on board can be characterised as a high-risk group. Furthermore, the analysis shows that 
accidents resulting in fatalities have decreased from 21 fatalities in the 5 -year period 2000-04 to 5 fatalities in the years 2010-14. Throughout the period 2000-14, the accidents leading to fatalities particularly occurred on trawlers $(77 \%)$ and boats with nets (18\%), with other fatal accidents on other types of vessels.

Overall, the reported accidents especially occurred on the deck, where crush injuries increased in the period 2000-2015, while fall and slip accidents slightly declined. The latter may possibly relate to the initiatives launched by the Danish Maritime Authority and the Danish Fishermen's Occupational Health Service.

Our analysis of the occupational accidents notified to the Danish Maritime Authority in 2000-2015 shows several characteristics:

- There has been a significant decrease in reported accidents from 2000-2015. While 53 accidents per 1,000 fishermen were notified in 2000, the Figure was 11.5 accidents per 1,000 fishermen in 2014.

- The reported accidents frequently involved ordinary fishermen.

- Accidents occurred every month of the year, the fewest in December.

- Most accidents occurred during fishing off the west coast of Denmark.

- The majority of accidents occurred on trawlers ( $69 \%$ of all reported accidents from 2000-2015).

- Accidents occurred typically on larger vessels with about 3 crew-members. In the Danish fishing fleet, the average crew size is about 1.3 people.

- More than one-third of the accidents involved fishermen who had less than one year's experience on the current vessel.

- The consequences of the accidents in terms of body damage have remained largely unchanged over the period 2000-2015. Most injuries involved fingers, hand/wrist and back. Altogether, these injury locations represent in total $45 \%$ of all reported accidents in the five-year period $2000-2004$ and $47 \%$ of all reported accidents in 2011-2015.

- The incidence of serious accidents (defined as accidents causing an absence from work for more than 2 weeks) decreased until 2006, but after 2006, the incidence of serious accidents has almost stabilised.

- The number of fatalities in connection with work in fisheries has clearly declined from 27 deaths in 2001-2005 to 4 deaths in 2011-2015. 


\subsection{Summary}

Based on the above, it can be concluded that the reported occupational accidents have decreased considerably. Several factors seem to have had an impact. The authorities have defined the framework and context and the Danish Fishermen's Occupational Health Service has provided multifaceted advice and support to the fishermen. The safety behaviour and the safety culture has improved considerably in general and currently there is a continuous dialogue on board and in the HSUs. Large parts of the fishing fleet have been modernised. The newer the vessel, the more potential risk factors have been addressed by considering them in the construction of the vessel. However, the Danish fishing fleet mainly consists of older vessels and the vessels' age is still increasing. In 1999, the average age of the fleet was 27.5 years, but in 2013 it has risen to 32.2 years (Christiansen, 2015).

The available studies have identified the risks and risk factors relating to the fishermen's work life. In recent times it seems that accidents are particularly concentrated in work on the deck and in larger trawlers, and that fishermen joining a new vessel implies an increased risk of work-related accidents.

Figure 27: Esbjerg harbour was previously the largest fishing port in Denmark. The fishery and the fishermen has disappeared, and the Fisheries auction closed in 2002

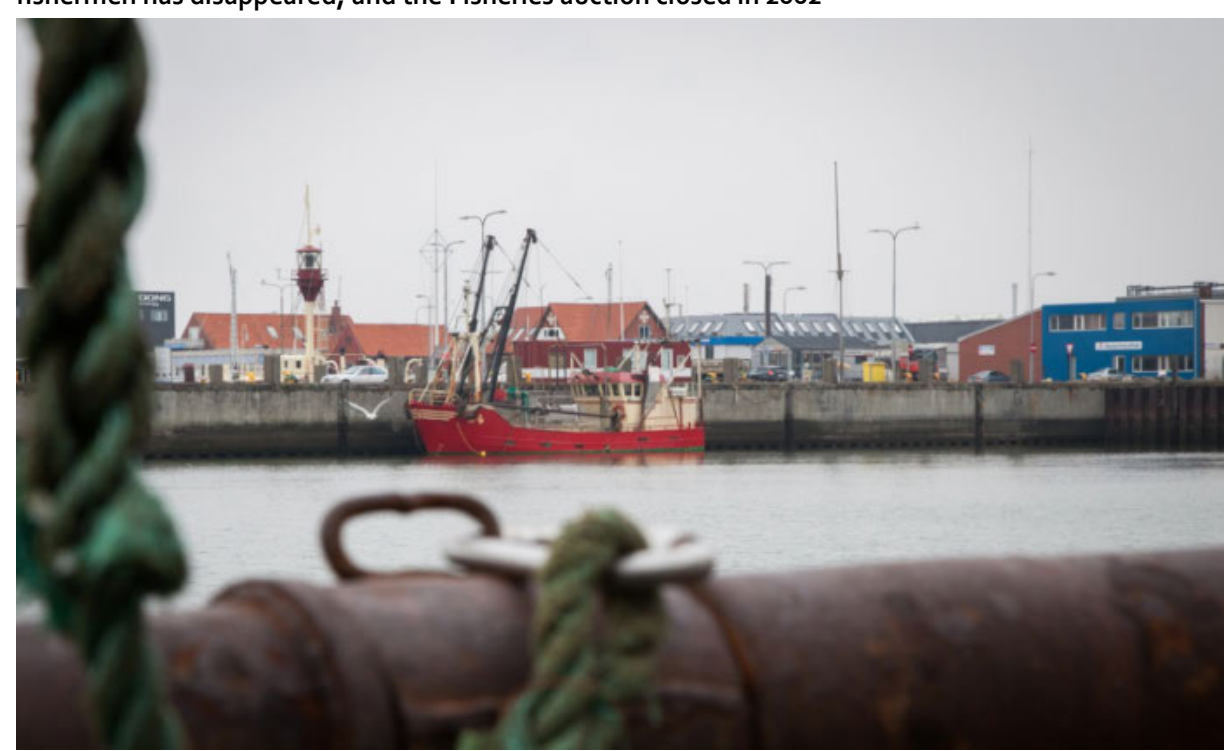

Photo: Michael Yde Katballe. 


\section{Summary - Nordic fishing, the regulation of fisheries and accidents in fishery}

The project is based on studies of accidents in fisheries in the Faroe Islands, Iceland, Norway, Denmark and Finland. The study shows that in the Nordic countries there are the last 15-20 years launched many diverse measures to prevent accidents in the fishing industry, as described in the summary for each country in previous chapters. There has been a significant decline in the number of fishermen in the Nordic countries in the observation period. While the number has approximately been halved during the past 15 years, the total catch is largely unchanged or has increased. The fishing fleet and catch varies across the involved countries. In Iceland and the Faroe Islands, the revenues from fishing constitute a significant portion of the countries' gross domestic product. These countries are mainly engaged in deep-sea fishing. This is in contrast to Finland, where the fleet consists mainly of small, one-man-operated fishing vessels and fishing in coastal or inland territorial waters. The Norwegian fleet consists of a mix of vessels, ranging from small one-man-operated vessels to large deep-sea vessels.

The countries' regulation and provision for safety at sea follows the international rules of the IMO and/or the EU. Fishing in the Faroe Islands has previously been regulated by Denmark, but in recent years the Faroe Islands has been attributed a greater independence and autonomy. Generally, the implementation and actual performance of occupational health and safety in fishery is very similar in the Nordic countries, but certain differences have also been identified, with Finland deviating in particular. One example is the requirement regarding education and safety training of fishermen, for which the legal requirement in Finland are less developed than in other Nordic countries. In relation to the requirements for risk assessment of fishery work, Denmark follows the rules of the European Union on workplace assessment, which differ from the other countries. In Denmark; the fishing industry has its own occupational health service (Danish Fishermen's Occupational Health Service), while most countries do not have a similar consultative, functioning service. Finland, however, has had a similar service for fishermen since 1984. The problem is that it is not mandatory for self-employed 
entrepreneurs, who make up the majority of commercial fishermen. This means that only about $15 \%$ use the service.

\subsection{The development in occupational accidents in the Nordic countries}

The trend in the incidence of occupational accidents in fisheries is hard to compare directly between the Nordic countries, because the reporting of accidents on which the data are based differs. However, the material makes it possible to formulate a reasonable description of the trend. The analyses in the pilot projects indicate a positive development regarding the incidence of accidents in the Nordic countries' fisheries, and today accidents are significantly fewer than previously. This is particularly the case for fatalities.

In Denmark, there has been a significant decrease in the number of reported accidents. While the incidence of accidents 15 years ago was significantly above the level of reported accidents for all industries in Denmark, the number of reported accidents was around the national average in 2014. In Norway, the rate of fatalities has been declining, with an incidence of 10.7 per 10,000 man-years in 2009 to 3.3 per 10,000 man-years in 2015. In Iceland, the number of notified accidents have decreased from around 55 accidents per 1,000 fishermen in 2002 to 30 accidents per 1,000 fishermen in 2015. In the Faeroe Islands, based on accidents reported to the Faroese Accident Insurance Council, a reduction in accidents was also identified from 1994 to 2002 . Subsequently, from 2003 to 2012, the level has been more stable overall, with about 25 accidents per 100,000 man-days. In Finland, there are no independent injury statistics on all commercial fishermen. It was therefore necessary to base the analysis on data from The Finnish Farmers Social Insurance Institution's (Mela) accident insurance (Mata). The Mata insurance is mandatory for all self-employed fishermen and their family members, if their fishing income is at least EUR 3,770 per annum (2016 level). $24 \%$ of all commercial fishermen in practice all full-time fishermen - are covered by the Mata insurance. This insurance system does not cover very small scale fishing, fishing outside the territorial waters of Finland, salaried fishermen and the majority of fish farming. The analysis shows that the estimated average injury rate was 7.9 accidents per 100 person-work years, with a slight downward trend over the observed period (years 1996-2015). 


\section{Part 2}




\section{Survey, the fishermen's view - Measures taken to prevent accidents in the Nordic fisheries}

\subsection{Introduction}

This part of the pilot project is based on the fishermen's individual experiences in relation to developments in occupational accidents and safety.

The starting point and the methodological approach are interviews with fishermen from the respective countries. The aim is to clarify:

- The fishermen's view on preventive measures to reduce occupational accidents in fisheries.

- The fishermen's view on what more should be done in the future.

- Recommendations.

In this part of the pilot project, it is essential that the involved countries have a common starting point, so that the value of comparisons is maximized. The countries involved therefore developed a common extraction criterion for selecting the respondents. All interviewed fishermen should at least have 10 years of experience in fishing. This selection is due to the assumption that fishermen are likely to have experienced developments in the attitude towards safety over the years and are also likely to have experiences in working with occupational accidents, which is the pilot project's main field of interest.

In the study of the first aim (see above), the researchers in each Nordic country together prepared questions based on part 1 of the project, that are supposedly measures of importance for the prevention of accidents in fisheries. The common questionnaire allows a comparison between the Nordic countries. It should be pointed out that some of the questions are adapted to each country's institutions; for example, Denmark is the only involved country that has an occupational health service for fishermen. The interviewed fishermen were asked to give their assessment of relevant factors that could influence risk and reduce the incidence of accidents. The assessment was on a scale of 
1 to 10 , where $1=$ little/no effect and $10=$ very important impact. If the respondent had no knowledge about the impact of a factor, they scored " $\mathrm{o}$ ". The questions/measures for which we asked for an assessment were:

- Safety training in fisheries?

- Other education in relation to fisheries and safety?

- Rules, auditing and controls by the authorities on safety and prevention in fisheries?

- Guidelines and information from the authorities on safety and prevention in fisheries?

- Investigation and recommendations from the authorities, e.g. the Danish Maritime Investigation Board?

- Use of workplace assessment onboard the vessel?

- The construction and physical layout of the vessel?

- Technical aids on board to reduce workload, e.g. lifting gear?

- Organisation of work on board. E.g. delegation of tasks, knowledge of what to do and who does what?

- Safety equipment for the fishermen and the vessel?

- The safety culture on board?

- Advice, help and support from consultants, e.g. the Danish Fishermen's Occupational Health Service?

- Advice and help from others, e.g. trade unions and organisations?

- Other? What?

In a structured interview situation, misunderstandings between the respondent and the interviewer can occur. The interviewer's agenda can influence the respondent in their answers so that they are led in a certain direction. Therefore the respondent gave a detailed reason for their assessment on each question, so that misunderstandings could be avoided.

Finally, the fishermen were asked to give their opinions on their attitude towards the future preventive efforts and the challenges they regarded as the biggest in terms of a further reduction in accidents. Furthermore, they were asked what advice they would give to a colleague who wanted to reduce the number of accidents. The fishermen's suggestions and responses relating to the continued efforts and recommendations will be presented in the pilot project's final conclusion. 
The following country descriptions will focus on the perceptions of fishermen from Norway, Finland, Iceland, the Faroe Islands and Denmark regarding the development in fisheries when considering the occurrence of accidents. What has worked?

Figure 1: Occupational hazards are present at every footstep in the fishers' environment on board their vessel

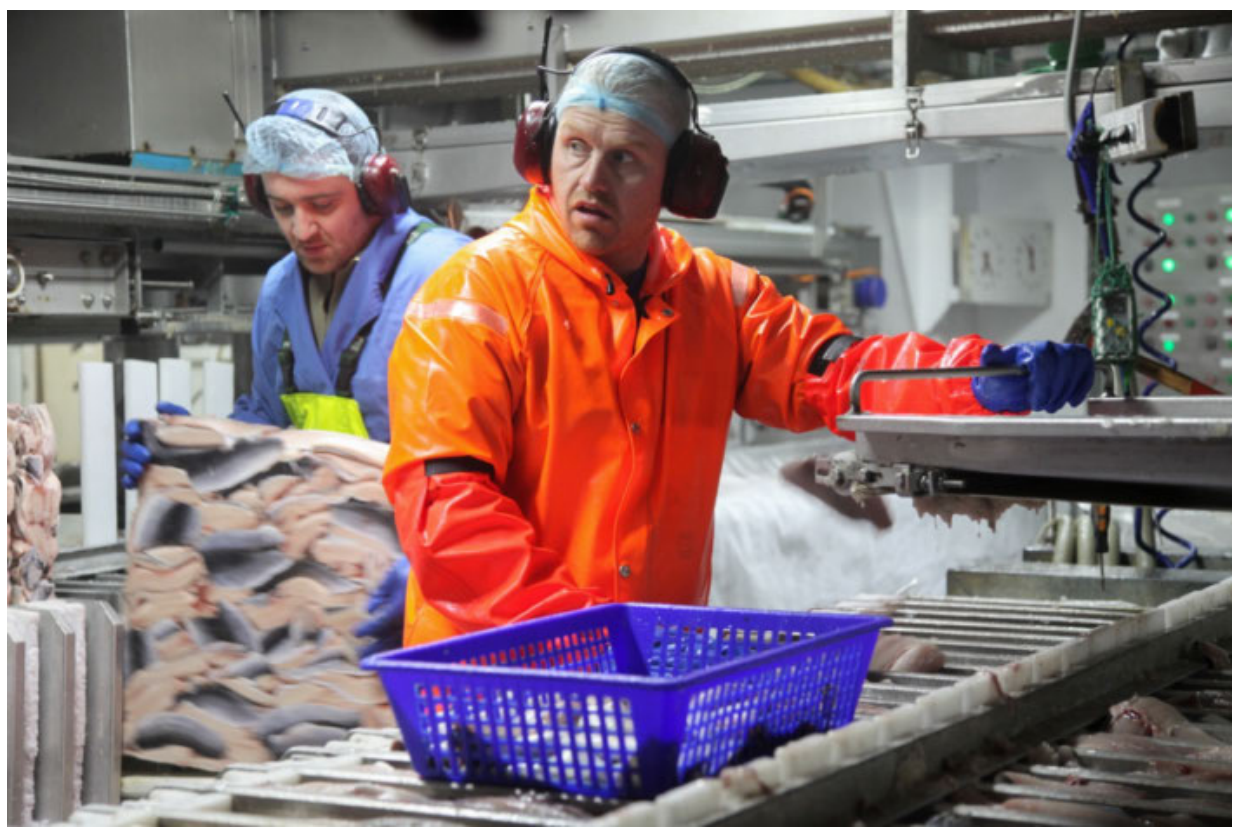

Photo: Hilmar Snorrason. 


\section{Norway: The fishermen's view - Measures taken to prevent accidents in the Norwegian fishery}

Authors: Trine Thorvaldsen and Signe Sønvisen. SINTEF Ocean.

\subsection{Approach and participants}

The Norwegian survey was conducted at Nor-Fishing 2016, a large fair for fishermen which takes place in Trondheim every other year. Participation was voluntary, and the only requirement was a minimum experience of ten years in the occupation. This approach did not screen for any other variables.

All interviews were personal. A random selection of fishermen were approached and asked if they would like to participate.

Amongst the ten participants who agreed to take part, there were seven skippers and three fishermen. Four of them worked on vessels below 12 metres, two on vessels from 12-40 metres, and four on vessels over 40 metres. This reflects the Norwegian fishing fleet fairly well: around 4,700 vessels in the Norwegian fishing fleet are below 11 metres, around 930 vessels are 11-28 metres, and 245 vessels are over 28 metres. One fisherman commonly operates the smallest vessels, and even though the largest vessels are fewer, they employ more people per vessel. Among the Norwegian participants, four fishermen worked alone, one vessel had two to three fishermen, one vessel had five fishermen. One vessel had nine fishermen and three vessels had crews of 16 to 18 people. Two vessels were trawlers, three vessels fished with nets, three vessels fished with nets and longlines and two vessels with longlines.

Although all participants had a minimum of ten years experience as fishermen, two of them had been on the current vessel for one to three years. Six fishermen had been on the current vessel six to eight years, and two fishermen had been on the current vessel for 28 years and 35 years. 
When it came to education, eight of the participants were educated fishing skippers. Two of the participants had no formal education. Safety training for fishermen is mandatory in Norway. All fishermen in the selection had completed the basic training, and followed the intervals for repetition courses.

\subsubsection{Accidents}

Two out of the ten fishermen stated that they had experienced accidents on board their vessel, whereas eight said that they had not. Both worked on vessels above 40 metres, with a crew size of 16-18 people. One of the participants had personally been injured in an accident. When the participants were asked what they had done to improve personnel safety on board, the following answers were given:

- personal safety equipment (such as helmets, life vest, hearing protection)

- safety line when working alone

- emergency stop for equipment on board

- emergency stop for the vessel engine (in case of man overboard)

- non-skid paint on deck

- safety management system

- risk evaluations

- on board training

- safety drills

- guidance from insurance companies.

\subsection{What has worked?}

Figure 2 presents the Norwegian fishermen's perceptions of what they think has worked and been important for preventing occupational accidents in fishing. In the interviews, each aspect was given a score between 1 and 10, 10 meaning a very positive influence, and 1 meaning a very low influence. If someone answered, "I don't know", the score given was 0 . The Figure shows the average scores for each question. Figure 2 provides abbreviations of the questions. The full length of the questions is found in Chapter 8.1 
Figure 2: Norway. Assessments of the relevance of 13 listed ways to promote occupational safety in fishing, the fishermen's response. Mean. Ranked ( $N=10)$

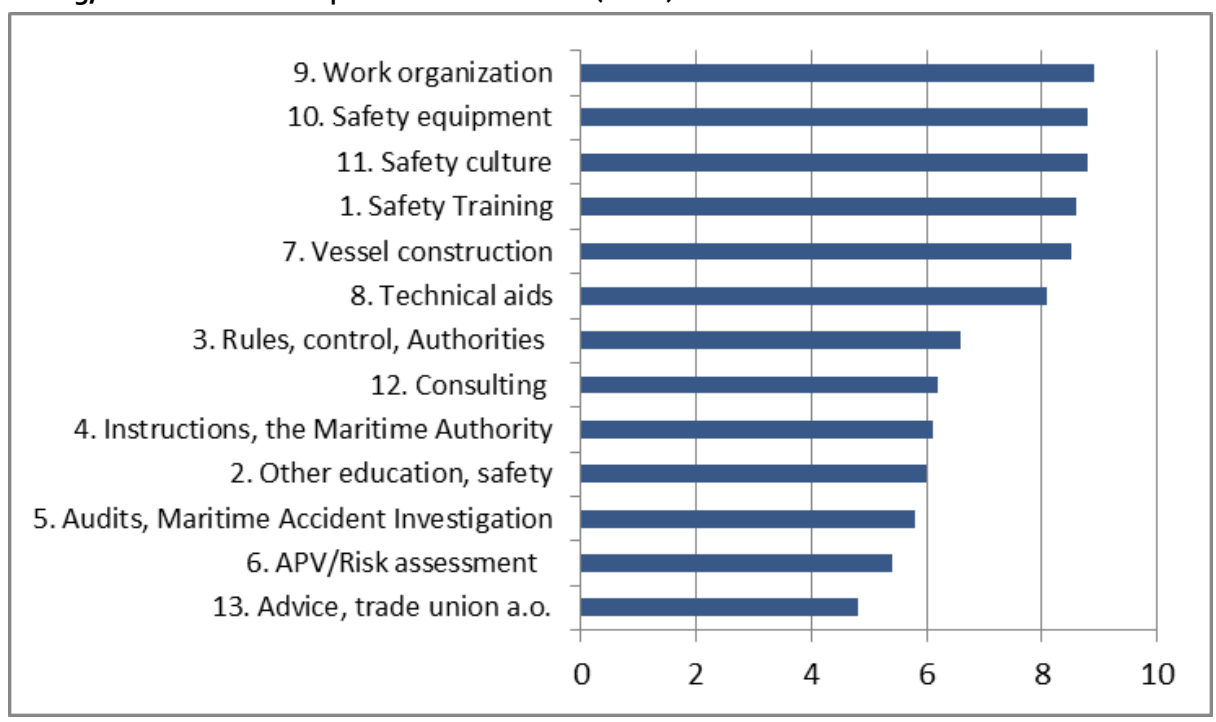

Source: Interview of 10 Norwegian fishermen.

The scores vary greatly in several of the answers, ranging from 2 to 10. In six of the questions the variation is smaller, and here the average score is over 8 (questions 9-1011-1-7-8). The ten Norwegian fishermen gave the highest scores to aspects related to the everyday work on board the vessels, namely how the work is organised, how tasks are distributed, onboard training (knowledge about what to do), as well as safety equipment for fishermen and vessels. A high average score was also given to safety culture, and several of the fishermen noted that there has been a pronounced change in safety culture during the last ten years.

In question 12: "Advice, help and support from consultants", the average score is 6.2. Three of the fishermen answered "I don't know". Other fishermen pointed to the importance of insurance companies. Some fishermen mentioned one particular insurance company called Tromstrygd that has worked with safety for many years and arranged safety seminars for fishermen, promoting safety equipment and counselling on how to operate vessels safely.

In question 6: "Use of workplace assessment on board the vessel", the average score was 5.4. Some of the fishermen answered "I don't know". Figure 2 shows that other scores are higher. This is question 3: "Rules, auditing and controls by the authorities on safety and prevention in fisheries (The Norwegian Maritime Authority)", question 4: "Guidelines and information from the authorities on safety and prevention in fisheries 
(Norwegian Maritime Authority)", and question 5: "Investigation and recommendations from the authorities (Maritime Investigation Board)".

There was only one question which had an average score below 5 . This was question 13: "Advice and help from others, e.g. trade unions and organisations".

All in all, the fishermen's perceptions of what has influenced safety work positively over the years are aspects related to actions that have taken place on board the vessels. The highest scores were given to: how work is organised, on board training, safety culture and safety equipment. Furthermore, the formal safety training for fishermen was given a high score. Rules, inspection and guidance have been of importance, but are not ranked at the top of the list.

\subsection{Challenges and advice for better safety}

What do fishermen see as the biggest challenges today and in the future regarding safety on board? The fishermen's answers to this question were:

- Safety awareness.

- Overboard accidents.

- Stability (smaller vessels).

- Lack of control and inspection on small vessels.

- The high age of fishermen (many old fishermen).

- Lack of drills.

Fishermen were also asked to give advice for better safety. The answers were manifold, but related to training, safety equipment, vessels and layout of deck, organisation of work, risk assessments, taking precautions, attitudes, control and inspections.

Several fishermen pointed out the importance of both on board training and formal safety training. One fisherman said there ought to be a stronger focus on onboard training, and others argued that they should have more safety training than today's requirement. It is very common to attend safety training individually with fishermen from many vessels. One skipper said they had taken the whole crew to the safety training at the same time and would recommend it to everyone. It gave them time to get to know each other outside the vessel and they could discuss what they had learned after they got back.

Fishermen focused on using safety equipment, including personal safety equipment, as well as emergency stops on machinery and vessels. When it came to vessels, 
one fisherman stated that new vessels are always better. Another said that it is important to take your time and Figure out the optimal layout on deck. Safety should be integrated in the technology to serve as a barrier towards accidents.

Many aspects related to organisation of work were mentioned, including management. It is important that shipowners take responsibility and are active in promoting safety on board. One fisherman emphasised the importance of risk assessments in all work operations, so that measures may be implemented and everyone is aware of potential risks and how to handle them.

It is important that everyone on board has good routines, meaning they perform their work in a safe way. Fishermen said that this is closely related to taking precautions in the work, such as taking breaks to avoid fatigue and using the weather forecast actively to evaluate if conditions at sea are safe. This is particularly important for fishermen in the coastal fleet, where vessels are more exposed to the weather.

A fisherman mentioned attitudes, and in particular attitude campaigns as a way to help raise fishermen's awareness of prioritising safety. In addition to this, control and inspections from the authorities were mentioned as an important part of the picture, in order to follow up safety regulations. 
Figure 3: Today's catch is taken on board

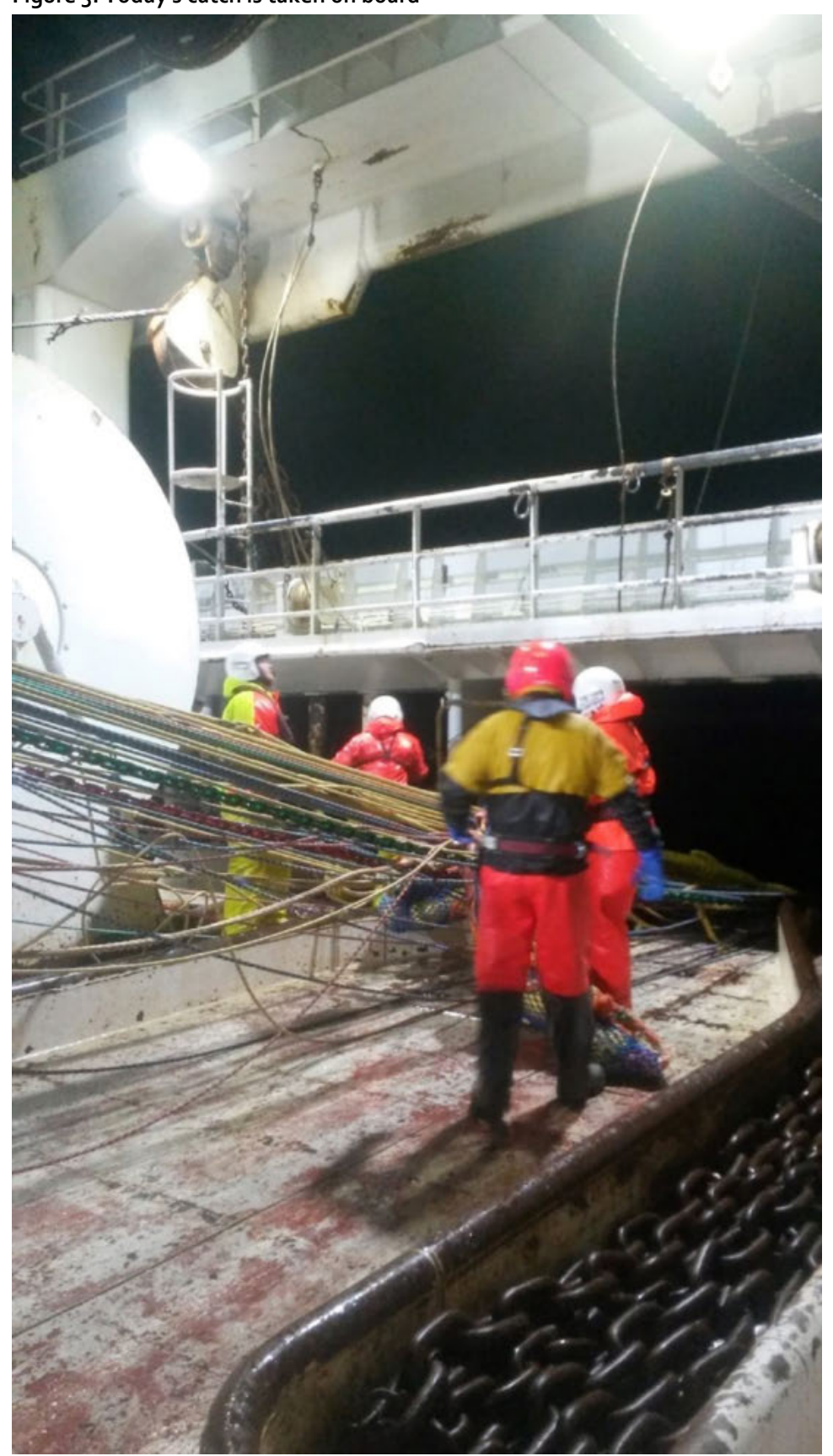

Photo: Annbjørg á Høvdanum. 


\section{Finland: The fishermen's view - Measures taken to prevent accidents in the Finnish fishery}

Authors: Kim O. Kaustell and Tiina E.A. Mattila Natural Resources Institute Finland.

\subsection{Introduction}

Ten Finnish commercial fishermen, who have been fishing at least 10 years professionally, were interviewed by telephone, using the common interview questions in this study. Contact details of the target group were acquired from the official registry of commercial marine and inland fishermen. The group of interviewees comprised eight fishermen who are fishing on the sea and two who are fishing on the inland lakes. One fisherman is only fishing on lake ice, using a dragnet. All but this one were skippers of their own boat. Four of the ten interviewed represented the Swedish-speaking part of the population, which reflects the actual proportion of Swedish-speaking commercial fishermen ( $34 \%$ in a recent study covering most commercial fishermen).

The fishing vessels were mainly open motor boats, along with one trawler and one motor boat with cabin. Lengths of the vessels ranged from 5.8 to 12.1 metres, which corresponds well to the bulk of registered Finnish fishing vessels. They had been in use by the fishermen for 14 to 30 years. Typically, there were at least two people aboard (5 cases), with three fishermen working alone and one vessel being occupied by three fishermen.

Most of the catch is sold to wholesalers, or directly for retail. Some fishermen refine some of the fish for seasonal sale. Two interviewed fishermen sold the fish directly to consumers. 


\subsection{Results}

Two out of the ten interviewed fishermen had experienced injuries themselves, but no injuries to the crewmembers were reported. In one case, the fisherman had broken his leg while fishing on ice. Another fisherman had suffered several injuries during the years: one due to tripping on the cabin doorsill, leading to a fall; another due to slipping on sea ice; and one lowering an outboard motor which resulted in a slipped shoulder joint. In addition, some minor injuries were mentioned casually. The fishermen also mentioned a sore elbow and sore knees, probably due to wear on the joints and ligaments.

Over the years, fishermen had done some safety enhancements on their vessels. Railings had been installed or made higher, and a felt canvas had been attached to the front deck to prevent slipperiness. In one case, the deck had been made flush to avoid tripping in stairs, steps, or doorsills. Steering control had been moved/added to a more appropriate place considering the fishing work. GPS and ultrasound equipment had been acquired to assist in navigation in fog.

\subsubsection{The occupational safety promotion method assessment}

Figure 4: Finland. Assessments of the relevance of 13 listed ways to promote occupational safety in fishing. The fishermen's response. Mean. Ranked

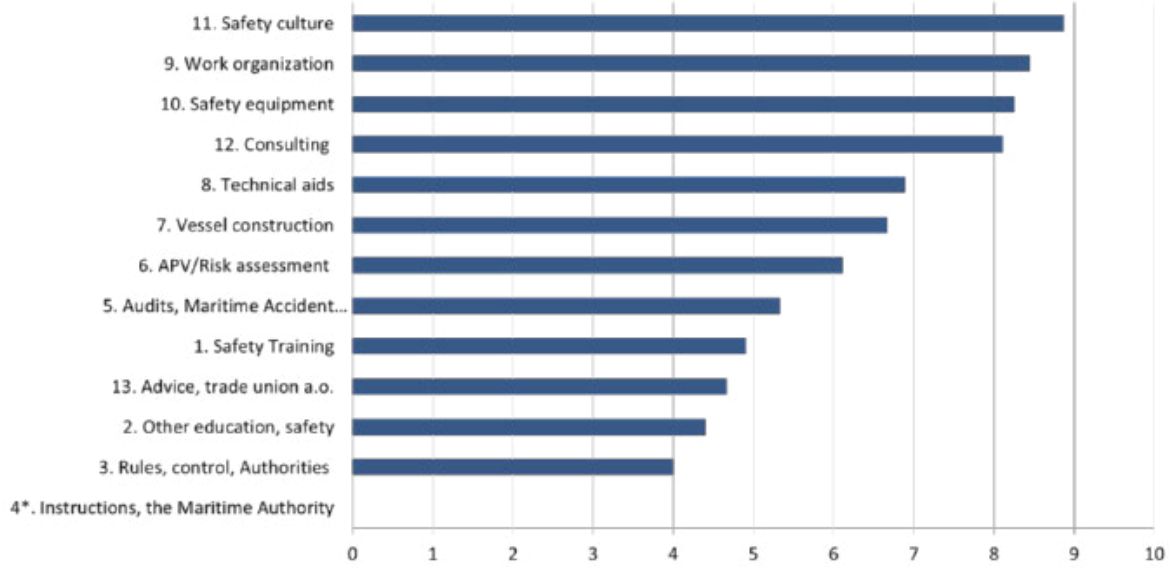

Note: * Question 4. In Finland, there are not published any "Guides, information etc. "from the authorities on safety and prevention in the fisheries. The matter was therefore omitted.

Source: Interview of 10 Finnish fishermen. 
The fishermen were asked to assess the relevance of 13 listed ways to promote occupational safety in fishing. The means of the assessments made by the ten interviewees are shown in Figure 4. The Figure provides abbreviations of the questions. The full length of the questions is found in Chapter 8.1.

Safety culture scores highest, with organising work safely, safety equipment, and advice and support from profession-related actors coming close in the next positions. Among the least-scoring ways were regulations, inspections, advice and help from more remote organisations, and education/training.

\subsection{The greatest challenges for safety prevention in fisheries}

The discussions and also some of the answers to the specific questions suggest that mental stress is a significant risk factor for at least some fishermen. The origins of mental stress can be multifaceted, but uncertainty of the future in fishing due to low profitability, accumulating and constantly changing legal demands and restrictions, as well as the effects of climate change and changes in the fish population due to various factors, are certainly some of them.

Besides mental risk factors, very practical hazards are also recognised. Working alone and various injury mechanisms resulting in drowning are mentioned.

\subsubsection{How can safety of seafaring be promoted?}

The growing problem of pleasure boat operators, especially new ones, not knowing the basic rules of seafaring has been noted on many occasions. The discussion of whether operators/skippers of pleasure boats should pass an examination to receive a licence before being allowed to operate a boat has been going on for quite some time in Finland. For now, there are only certain age limitations with respect to what size of pleasure boats (motor power) may be operated. The Finnish coastal waters are for the most part very shallow and rocky, and it may be very risky for the fishermen to start emergency manoeuvring in order to prevent a collision.

Limited resources to maintain emergency response service levels has probably resulted in lower readiness and longer response times to engage in SAR activities, at least in some areas.

Inspections, especially for bigger vessels, were suggested as a safety-promoting measure. While inspections and regulation enforcement were ranked low in the assessment of effective safety measures, safety-enhancing construction of boats was ranked high. Safety should be "built in" and "built to last" in vessels. On the other hand, natural 
deterioration, repairs and rebuilds make the low ranked inspections essential. The question arises whether the inspections in their current methods of execution do serve the fishermen or just law enforcement and thus are only a "necessary evil". A more consultative or advisory type of service might be more beneficial. At the moment, regular inspections are mandatory - depending on the operating area - only for vessels over 10 metres in length.

\subsubsection{Advice topics for peer fishermen}

Informal learning from more experienced peers is the suggested way to actually transfer safety knowledge. This is fully in accordance with the assessment of the most effective ways to promote occupational safety. Use of personal protective equipment, as well as making working processes and the working environment safe, are certainly the practical things that need to be discussed and reinforced on all occasions. These are probably also things where the example of experienced peers has great influence.

If new to the local conditions, the sea, or to the behaviour and operation of the vessel to be used for fishing, paying special attention to the current and predicted weather is of key importance. Weather patterns are also slowly changing with the climate change.

\subsection{Discussion and remarks}

The interviewed sample is very small due to the practical limitations of the study. It still represents the fishing area and native language distributions in Finland quite well. The insight gained from the interviews reflects the earlier impressions of a self-sufficient, competent, small-scale professional entrepreneur, who "knows what (s)he is doing" and is annoyed by some introduced regulations and restrictions concerning when, what and how it is legitimate to fish.

It was pointed out that continuous rocking of the boat is a significant contributing factor to knee problems. A reason for trips and falls was also mentioned: "When you get old, you become clumsy and lazy to lift your feet enough. That's when you start tripping over things. "With age, maintaining balance also becomes harder, which may be a problem associated with fall injuries of the ageing fishermen population.

Generally, the importance of working safely and using e.g. a flotation vest and safety-enhancing equipment, and constructions on the vessel were recognised. However, two fishermen mentioned that some technical aids, like winches, may not be feasible on small boats. In earlier interviews, it was also mentioned that the eligibility for 
investment subsidies to install safety equipment may be conditional: one has to commit to continue in the profession for a certain number of years. For older fishermen, and in a weakened profitability situation, this may construct a barrier for actually enhancing safety on board.

\subsection{Summary}

With reasonable generalisation, the results of the Finnish interviews can be summarised as follows:

- The fishermen ranked highest, or most effective, measures that they themselves control; that require cognitive commitment and shaping of their own work and working place; and are executed "on the job"(items 11, 9, 12).

- Scoring next highest were some very practical and physical/concrete measures (items 10, 8, 7, and 6) that can be (or have been) implemented in the workplace.

- A third group of measures, that received lower assessments, comprises formal competence building (mostly not on-site, items 1 and 2), as well as information and enforcement "from outsiders (to fishing)" (items 5,13 , and 3 ).

These concluding observations give justified guidance for planning and executing effective occupational safety interventions, and they should be followed.

The promotion of seafaring safety was seen as something that would require legislative interventions, i.e. more strict licensing for pleasure boat operators, more useful and service-oriented, regular fishing vessel vetting, and maintenance (= funding) of an adequate SAR (Search And Rescue) readiness.

\subsection{Acknowledgements}

This study was supported by The Nordic Council of Ministers and Natural Resource Institute of Finland. The Farmers' Social Insurance Institution (Mela) provided the injury data for the study. 
Figure 5: The owners and crews of fishing vessels have changed their attitude to safety. This change has improved safety and work environment and has led to reduction of accidents

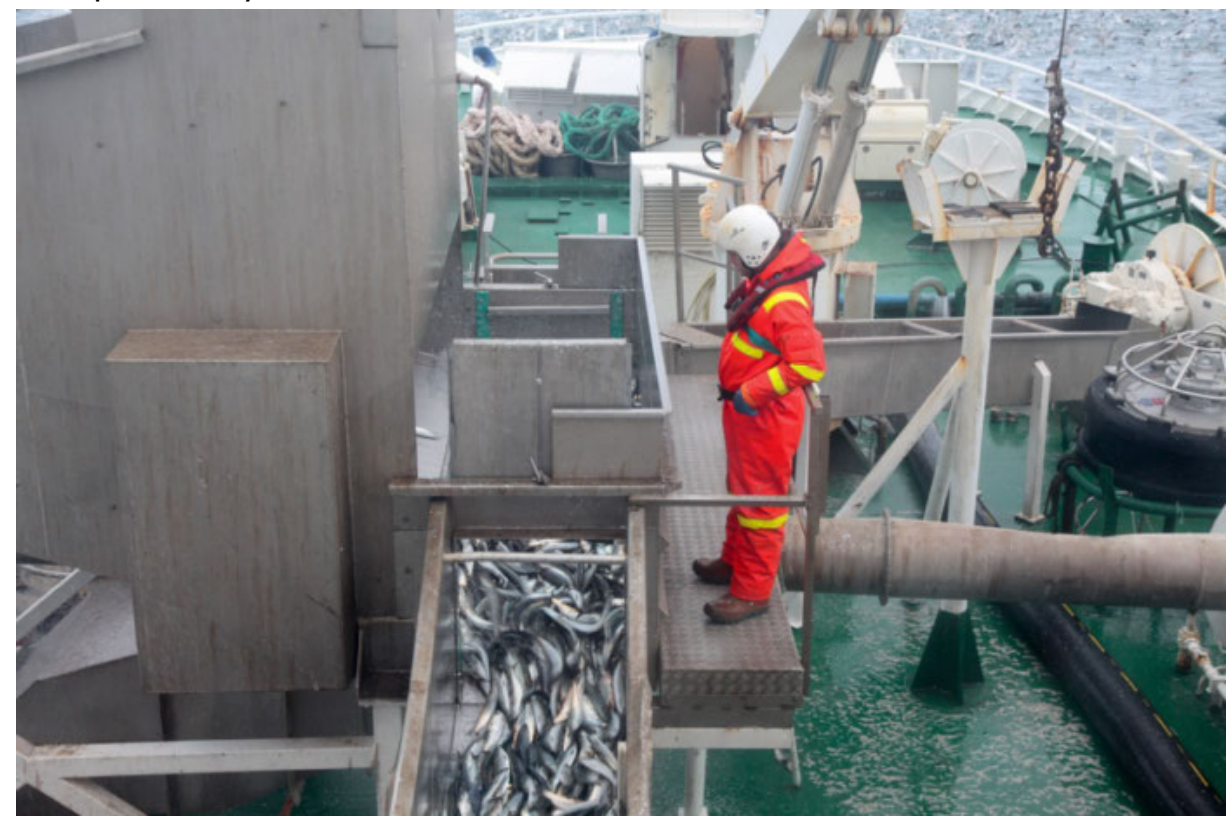

Photo: Hilmar Snorrason. 


\section{The Faroe Islands: The fishermen's view - Measures taken to prevent accidents in the Faroese fishery}

Authors: Annbjørg á Høvdanum Department of Occupational Medicine and Public Health, Faroe Islands and the Faroese University.

\subsection{Background}

10 fishermen agreed to participate in interviews about which actions they think have reduced accidents in fisheries. The criterion for participation was: at least 10 years of fisheries work experience. This was to ensure experience with accidents and the risks involved in fishing, along with knowledge and personal opinions about what has improved safety and lowered the number of accidents at sea. Table 5 summarises the descriptive statistics about the fishermen and their ships.

Table 5: Descriptive statistics of interviewed fishermen ( $\mathrm{N}=10)$

\begin{tabular}{lrrr} 
Descriptive statistics & Mean & Minimum & Maximum \\
Work experience (years) & 23.75 & 12 & 48 \\
Age & 41 & 33 & 62 \\
Manning level & 16.9 & 4 & 42 \\
Length of trip (days) & 18 & $2-4$ & 60 \\
Length of ship (m) & 54 & 19 & 110 \\
Age of vessel & 26.8 & 14 & 38 \\
\hline
\end{tabular}

Two fishermen worked as captains, 4 as deckhands, 3 as cooks and 1 as a factory foreman.

Their fishing methods are divided as follows: 1 netting vessel, 2 longlines, 2 combined methods purse seiner and trawl and 5 trawlers $(1 \times$ pair trawler, $2 \times$ industrial trawlers, $1 \times$ trawler group 2, and $1 \times$ small trawl boat group $4 \mathrm{~T}$ ). Of these, 9 catch fish for consumption while one is selling for both purposes. 
There is a large variation as to how long the fishermen are out fishing. The time spent is dependent on vessel type and catch. The purse seiners and the industrial trawlers have 2 crews. The same goes for some of the pair trawlers, but on most pair-trawlers, the officers go $1-1$, and it is the same for about half of the longliners, while the rest of the fleet only has one crew.

Many of the ships have gone through renovations and reconstruction, including safety enhancements, such as installing railings or making them higher, and most decks now have anti-slip surfaces.

\subsubsection{Experience with work accidents}

All the fishermen had witnessed accidents at some point in their fishing career and nine of them had witnessed accidents on board their current ship. Eight out of ten respondents had witnessed an accident within the last two years, while the one who had had the longest accident-free period had witnessed his last accident back in 2008. Seven of the interviewed fishermen had experienced accidents to themselves, some more than once. Two of the three cooks were cooks because of accidents and reduced physical capacity as they were no longer fit for the heavy work on the deck.

Although 7 out of 10 had experienced accidents to their own body, only half of these were reported. Reporting usually occurred if the accident was greater in severity and resulted in longer sick leave. However, a broken hand had also not been reported (albeit 40 years ago).

All fishermen had personally tried to improve safety at some level. Those in leading positions did so by informing crewmembers about safety, organising safety training and involving their crewmembers in maintenance, in order to raise awareness about safety and the safety equipment. The fishermen on deck warned each other of dangers, trained new crewmembers and used safety equipment, and reminded each other to use it.

\subsection{The Fishermen's view on agents that have been installed for the purpose of reducing occupational accidents in fisheries}

The interviews lasted between 20 and 57 minutes. Four of the interviews were done sitting down face-to-face with the participants, while six were completed over the phone. The structure of the interview was first to collect background information about the fishermen (descriptions above) and hereafter special attention was paid to possible means that may have contributed to the prevention of accidents in fisheries. The identical questions and rating system were used for all the participating Nordic countries 
(See chapter 8.1). Figure 6 provides abbreviations of the questions. The full length of the questions is found in Chapter 8.1.

Figure 6: The Faroe Islands. Assessments of the relevance of 13 listed ways to promote occupational safety in fishing. The fishermen's response. Mean. Ranked ( $N=10)$

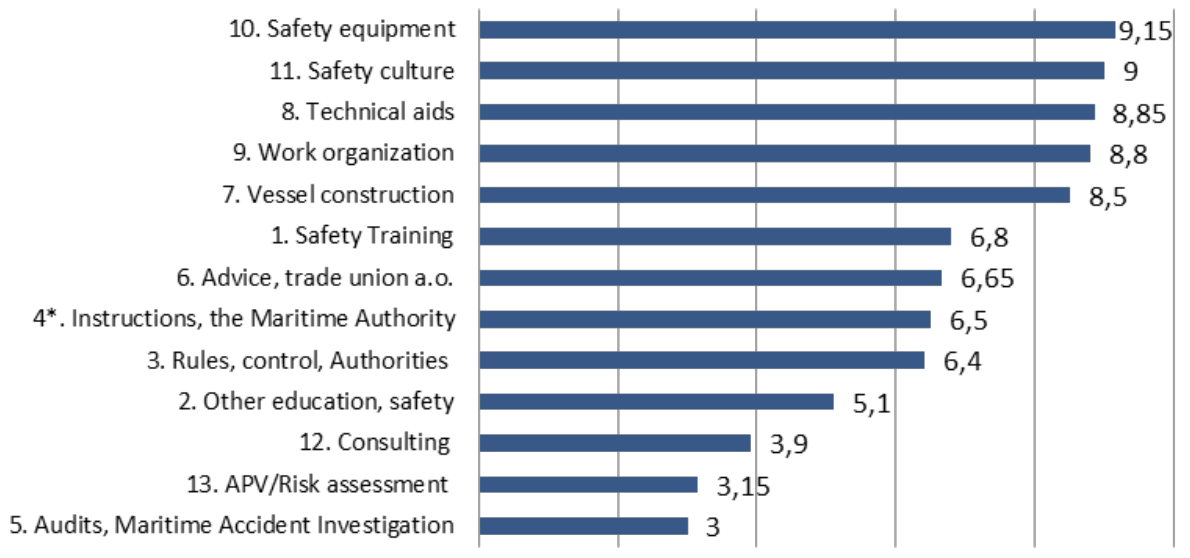

Source: Interview of 10 Faroese fishermen.

To avoid manipulation of the results and to ensure that the respondents had not misunderstood the questions, they were asked to give a verbal comment to each of their numbered answers.

Above we see that the fishermen gave the highest ratings to things that are directly connected to daily life on board. The highest rating was given to question 10: "Safety equipment for the fishermen and the vessel" (9.15), closely followed by question 8: "Technical aids on board to reduce workload, e.g. lifting gear" (8.85), and question 9 and 11: "Organisation of work on board. E.g. delegation of tasks, knowledge of what to do and who does what" and "the safety culture on board" (both 8.8) and thereafter question 7: "The construction and physical layout of the vessel" (8.5).

Ten of thirteen questions have been rated with a mean of five or higher. These are: $1,2,3,4,6,7,8,9,10$ and 11 . Apart from questions $7-11$, there is a large spread in the answers, with the majority spreading over a range of $7-10$ digits. From the comments, it seems that this is largely explained by the different positions on board. For example, captains gave high scores to the use of workplace assessment onboard the vessel and to question 5 about the investigations and recommendations from the authorities. The rest of the crew had less knowledge of these factors, although some could see how the investigations could prevent similar accidents in the future. 


\subsubsection{Questions and the fishermen's response}

Question 1: Safety training in fisheries

The spread of answers to this question ranges from 2 to 10 , with a mean of 6.8. Most agreed that safety training was good, but shared the opinion that it contains too much theory and has too much focus on how to cope when an accident occurs, rather than preventing it. One of the fishermen, who rated it 10, said "I think that the safety training is very important, as some jobs are dangerous, but you have to do them anyway". Another who rated it 8.5 expressed that he appreciated the improvement, since there was no safety course when he started fishing. The fisherman who gave the lowest score to this question said "The content of the course has too much theory and too little preventive practice. We mostly learn what to do in case of an accident, and not how to prevent them, which I think should be the crucial part".

Question 2: Other education in relation to fisheries and safety

The spread of answers ranges from 1 to 7 , with a mean of 5.1.

This question required an additional explanation of what we were asking for, as participants had just beforehand answered about safety training for fishermen. Also the majority of the respondents in this interview were fishermen without other educational certificates, so for them the fishermen's safety training was the only thing that was required. One who rated it as a 7, answered: "Everything that one tries out in person, helps. I think that the on board follow-up of the safety courses is equally or more important than the courses themselves". A deckhand, who rated the relevance as a 7, said I think the deckhands build experience as they work, so in fact we learn all our working life". Another one, who rated additional training as a 7, had a certificate in fire training in addition to the obligated training. He felt that this was very important and another agreed with him, stating: "all fishermen should receive firefighter training. It is very important to know how to extinguish fires on a ship".

Question 3: Rules, auditing and controls by the authorities on safety and prevention in fisheries The spread of answers ranges from 4 to 10 with a mean of 6.4.

Most agreed that rules are important. One respondent, who rated it at "o", emphasised that "When you are on the deck or in a dangerous situation you will rely on experience more than anything else", while respondents who rated it higher said "Iffollowed then it is good, but this depends much on the captain. For example, how often or if any safety training is conducted on board". Thus, the fishermen valued it and saw it as important, but could see some limitations with a captain who did not value it. One, who rated it as 
an 8, said "safety has improved very much since I started working at sea 44 years ago. I am glad that I have learned how to extinguish a fire". He appreciated the rules generally, e.g. fire extinguisher equipment and oxygen. Another respondent, who rated the importance as a 10, said "Members from the control ship have been onboard our ship 4 times this year. This helps us to keep things up to date".

Question 4: Guidelines and information from the authorities on safety and prevention in fisheries

The answers range from 2 to 10, with a mean of 6.5.

Most of the respondents rated this question as a 6 or higher. They said that they read the information, if posted where they could see it every day. One respondent, who gave it top rating, said "Now everybody knows where to go and how to act if in danger" and another one said "It is helpful when hung up on places where one sees it daily. E.g. on the toilet door". Others were sceptical about the FMA's control, as they felt that some of the inspectors knew too little about fishing. One, who rated it down as a 4, said "Fishermen block down when someone comes from the outside to tell us what and how we should do things". This strongly supports the argument that it is more effective to have a dialogue with fishermen, rather than acting in the role of "the know-it-all" authority.

Question 6: Use of workplace assessment on board the vessel

The spread of answers ranges from o to 10, with a mean of 6.65 .

Most fishermen rated the importance of the APV (workplace risk assessment) very high, and thought it made them more conscious about important safety matters on board. Two fishermen rated it low, because they did not use it or did not know that it existed. One of the respondents, who rated it to have high relevance, said "/t is good, because it puts a pressure to get things up to date, as well as one becomes more conscious about it."

Question 7: The construction and physical layout of the vessel The spread of answers ranges from 7 to 10 , with a mean of 8.5. This is also the question that has the least variance, together with question 9.

All respondents agreed that layout is very important in promoting safety and reducing accidents and injuries from work. They told stories from different ships they had been on, and compared workability and risks. One fisherman said: "The new ships are alright. The older ones would need to bring the standards up to date, but it is always a question of money and lost income, if it has to be done". Another said: "It is especially important with good railing, to decrease the risk of going overboard, with breaking waves". Besides the reduction in accidents, the fishermen also valued the layout of a ship, for 
practical reasons. One said: "It makes it easier and more fun to work on a well-designed ship, as well as it reduces the physical workload and work injuries". Injuries because of bad working conditions, are not accidents, but are also disabling in the long run".

Question 8: Technical aids on board to reduce workload, e.g. lifting gear

The answers range from 6 to 10 , with a mean of 8.85 .

This is the second highest rated question. Everyone agreed that technical assistance aids have reduced the number of accidents and the work burden significantly. One said: "It has made an enormous difference that fishermen do not have to do as much of the heavy work anymore, e.g. carry heavy burdens". Another stated "it has been a good help in reducing the occurrence of back pain and injuries in the fishermen". The mean age of vessels in the Faroese fishing fleet is quite high. With regards to this, one respondent said: "Work is much easier on-board the newer ships, but we still have a lot of old ships, 20-30 years old and older that do have very limited technical assistance".

Question 9: Organisation of work on-board. E.g. delegation of tasks, knowledge of what to do and who does what

All the fishermen agreed that this is a crucial factor in lowering the accident rate. This is also reflected in the spread of scores. The answers range from 7-10, with a mean of 8.8. One said: "it is extremely important that everybody knows what to do and that men talk about these things". The majority thought that the organisation of work was alright on most ships. One fisherman said: "Ifyou don't know what to do, or do not communicate with the other crewmembers, it can quickly result in danger for your co-workers. If one wishes to be a fisherman, communication is a fundamental requirement". Another one said: "as soon as we do not communicate, an accident is doomed to happen". He was referring to serious accidents that have resulted in lost lives, where an inability to communicate properly because of language difficulties was one of the core problems.

Question 10: Safety equipment for the fishermen and the vessel

These answers range from 5-10, with a mean of 9.15. There seems to be quite a gap between what the fishermen rated as important and how they were satisfied with the state onboard their ships. For example, one said: "This has made a large difference, but these things are not very favourable onboard my ship". Another one said: "This is the most important thing of all, but unfortunately, many captains don't prioritise time for safety training." Another one said: "This has been extremely important in reducing accidents. For example, the flotation suit". In highlighting the importance of onboard training, one who rated this question as a 9 said: "Very important, if used right. There is a saying that more 
lives are being lost to a $M O B$-boat, than saved, so you need to be trained in handling the MOB-boat".

\section{Question 11: The safety culture on board}

Here the answers range from 7 to 10 , with a mean of 9 . There is some variation on how satisfied they were with the degree to which it was practiced on board their ship. However, all agreed on its high importance. One rated it as the most important onboard a ship, while one said: "Very important, but we practice it too little". Another said: "Very important, and we are reasonably good at practicing it. We talk about safety and have a meeting once a week, where we discuss safety and other relevant subjects" a third says: "Very important, and we value it highly on-board on our ship". One says: "it is an unwritten law, friend or enemy, you always help, when there is danger". Another one says: "There is a large difference between the safety culture on Greenlandic and Faroese trawlers we are far behind on this matter".

Questions 5,12 and 13 all have in common a mean below 4 . In addition, most of the fishermen seem to have quite a low level of knowledge and experience with regard to these themes.

Question 5: Investigation and recommendations from the authorities, e.g. the Danish Maritime Investigation Board

The answers range from 1 to 8 , with a mean of 3 .

The respondents seemed to have little knowledge about and interest in these investigations. Generally, they seemed to think that it was of less relevance to them than the officers. One said: "It is hard to put a number for this one, but I guess it has helped to improve safety, e.g. this is the reason for why we now got sprinklers onboard". This one rated its relevance as a 5 and another said: "I know that this is more used by the officers. It is less relevant to me, as the responsibility regarding safety or fire situations on board is on them". This respondent rated its relevance in reducing accidents with a 6 . Others found it harder to see that reading and hearing of other accidents could help them to prevent it happening to themselves. One said: Regardless of how good and how up to date a ship is, the accident will happen when it happens. 2 seconds where you look the other way, is enough. If one fisherman is half asleep on the deck, then an accident is more likely to happen". The only respondent who rated it with 8 was a captain. 


\section{Question 12: Advice, help and support from consultants}

The ratings on this question ranged from 1 to 7 , with a mean of 3.9.

Probably the largest single explanation for such a low rating on this question is that seeking external advice is not much practised in the Faroe Islands. This is also the comment that 3 of the respondents put forward. Furthermore, we do not have consultants that offer guidance and support to fishermen regarding safety. One said: "External advice, or help from consultants, has never been used by any ship I have been on". Some seemed only to think of the consultants as persons who imposed their advice on them and not something that they received because of their own request. E.g. one said:" In my opinion, you can't force safety onboard a ship. It requires that the officers take it in, and when they do, then you will see changes in the rest of the ship.

Question 13: Advice and help from others, e.g. trade unions and organisations The ratings on this question ranged from 1 to 8 , with a mean of 3.15. Many of the respondents seemed to think of the trade unions as agents responsible for the area of defending their legal rights, mostly with regard to payment, and less with regard to actively promoting safety. Some members of the unions shared this opinion. However, the unions have been very supportive around safety projects concerning fishermen's safety. For some, the opinions were built on personal experiences from asking for advice, and for others they were based on a more global view. One said: "I contacted my trade union once, after we had been out for 105 days without seeing land, and felt like we were going insane, but I got no response". Based on this, he concluded that help from unions has not reduced accident rates. Others thought about what could happen and based their answer on this: "It would be good if they could give new information on something we do not know", while others based their opinions on the concrete actions that they thought made a difference in reducing accidents, e.g.: "The fishermen's wives' organisation campaign "o\% alcohol on ships" gave good results, because it started some reflection in fishermen about this behaviour". While another said: "the effect of the fishermen's wives' campaign has lowered again, and many fishermen start their trip drunk. But at least, the captains are still sober". Others simply stated that they had never received external advice. 


\subsection{The future}

\subsubsection{What do you see as the largest challenge in reducing the number of accidents today?}

There are 4 themes represented in the answers to this question, with some sub-themes.

The first theme concerns communication between the officers on the bridge and down to the engine room. Two respondents said that these parts do not always value each other's work and they do not offer understanding for the importance of the other part. This results that they sometimes seem to work against each other, rather than working as a team, where both parts are equally important for the optimal function of the ship. These fishermen thought that this competition over who is more indispensable sometimes results in safety knowledge not being shared optimally among officers and the rest of the crew.

The second theme is the function and use of equipment. Some of the older ships are worn out, and there is a high need for maintenance and reparation of things that are out of order. Also, technological assistance is very limited, although some installations of equipment have been made. These break-downs and the lack of automatic safety installations are a constant threat to the safety of the fishermen. On the other hand, newer ships with the new technology sometimes have a problem. This is especially the case in factories when the workers do not get sufficient training on how to handle the new technology. One respondent said: "It takes time for the technology and fishermen to "work together". The new machines require knowledge and training before you can use it". He suggested that fishermen should get training on handling these machines before they get on a ship. Although there have been some accidents associated with learning to use the new machinery, most agree that the newer the ships, the fewer the accidents.

The third theme is rolling. Some ships in the Faroese fishing fleet do not have stabilisation tanks. One said that if it would become mandatory that all ships should have stability tanks installed, this would lower the number of accidents instantly.

The last theme concerns alertness. Fishermen always need to be attentive with everything that goes on around them One respondent was a bit worried about the young workers' use of music in headphones, as he did not think they would hear something irregular or a warning shout from co-workers when they needed it. The constant pressure to be the best fishing ship leads to fishermen pushing themselves to work harder and to do better than the trip before. This was mentioned as a key fatigue problem. One fisherman said, "it only takes 2 seconds of inattention for an accident to happen". 


\subsubsection{What could improve safety at sea?}

A few suggestions were generated regarding improvement of safety at sea. Almost half requested legislation that bans them from fishing in bad weather. They said that although they know it is not the best thing to do, they will do it anyway if allowed to, because of the pressure to fill up the ship as fast as possible. One also put forward that changes to the quota system could make a difference. He said: "we have to work full speed all the time, to catch as much as possible in as short a time as possible, as some quotas are calculated on time". Changes to this could reduce fatigue-induced errors. He continued: "Nor can we plan ahead optimally, because the quota permissions are divided between the ships quite late in the year and this causes more frequent changes of equipment than otherwise needed. The equipment is heavy and dangerous, and causes serious accidents if a crewmember gets hit". Others requested more information about safety clothing and put forward the importance of the ship being tidy.

One respondent stressed the importance of fishermen needing to be careful and to watch themselves and their co-workers, and that all fishermen need to know how to use the equipment correctly. E.g.: cranes, wires, the scrubber.

\subsubsection{If a workmate contacts you to get advice on what is the most important thing one can do to reduce accidents in fisheries, what would you answer?}

Listen to your crewmembers, and ask if in doubt. It's better to ask once too often that once too little. Do not try to play a hero and put yourself in an impossible position. It is important to reason and to help each other where possible. You should always be alert and pay attention, because there are many dangers. Always keep your eyes and ears open and know what happens around you. Always use the safety equipment available, follow procedures and beware. Treat the machinery with respect, and do not forget the maintenance.

\subsubsection{Other remarks}

A net below the gangway has rescued many men and could have saved someone's life, so this should be mandatory.

Hands-on experience and routine at sea is most important in reducing accidents.

The length of trips was mentioned as an important factor that influences the risk of accidents. There is a law on the maximum length of a trip, but it is questionable how well this is being followed.

Furthermore, more control and checks for alcohol before leaving the harbour were also requested. 


\subsection{Summary and conclusion}

To summarise the results, we see that things that directly influence the fishermen's daily work on board get the highest ratings. E.g.: layout of the ship, technical aids, the organisation of their work, the fishermen's safety culture and safety equipment, i.e. things that are very measurable and that they can access on a moment to moment basis. Next comes safety training, together with assistance, regulations and legislation. These are also something that they are in direct contact with or feel the influence of on a regular basis. The lowest relevance in reducing the number of accidents was given to external consolations and interventions conducted by the DMAIB or FMA. These are also the factors that are the farthest away from them and which they have the least contact and experience with.

It seems that it is of great importance for fishermen to be able to see the direct link between the intervention and the outcome and that these are rated accordingly. E.g. regulations about safety equipment are in many cases a result of accident investigations by the DMAIB, but this background is not as visible and tangible as knowing that a respondent was warm, dry and floating because of a flotation suit. When the change is first implemented the reason for it falls into the background.

All the fishermen agreed that things have improved. However, those who have been fishing on foreign ships highlight that the safety culture on these ships is far better than on Faroese ships. 
Figure 7: Sophisticated fishing processing plants in contemporary vessels have added further dangers to the fishermen's daily work

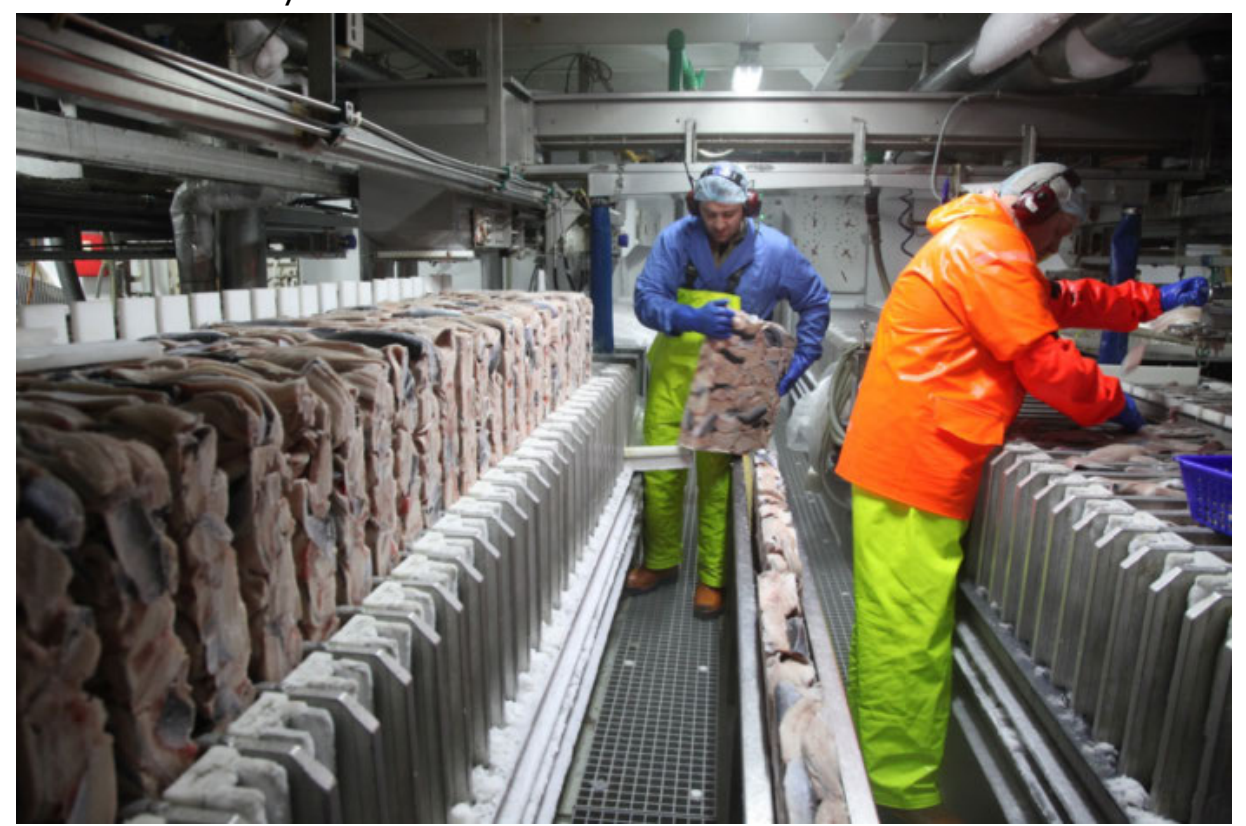

Photo: Hilmar Snorrason. 


\section{Iceland: The fishermen's view - Measures taken to prevent accidents in the Icelandic fishery}

Authors: Kristinn Tómasson and Hilmar Snorrason. Administration for Occupational. Health and Safety, Reykjavik, Iceland.

\subsection{Background}

The initial plan was to talk with 10 fishermen. However, after repeated phone calls and after two months, only six had responded. The phone conversation had to be postponed on a number of occasions as the fishermen were out at sea. One fisherman did not want to participate.

These fishermen have longstanding experience with well over 10 years of fishing experience. They represented both officers and deckhands, crew from bigger and smaller ships. All of them have experienced an accident onboard, either to themselves or others. They came from different positions on ships with sizes ranging from 12 to 90 metres. They were all fishing for fresh fish, for fish markets, or in the case of the trawlers with options for iced products.

The smaller vessels with 2-3 man crews did not have a formal occupational risk assessment plan, while the larger ships with 10 crewmembers or more did have such a plan in a formal setting.

The interviews were based on the joint Nordic questionnaire, with the aim of highlighting the measures for the prevention of occupational accidents in fisheries (see Chapter 8.1). Figure 8 provides abbreviations of the questions. The full length of the questions is found in Chapter 8.1. 


\subsection{Results}

Figure 8: Iceland. Assessments of the relevance of 13 listed ways to promote occupational safety in fishing. The fishermen's response. Mean. $(\mathrm{N}=6)$

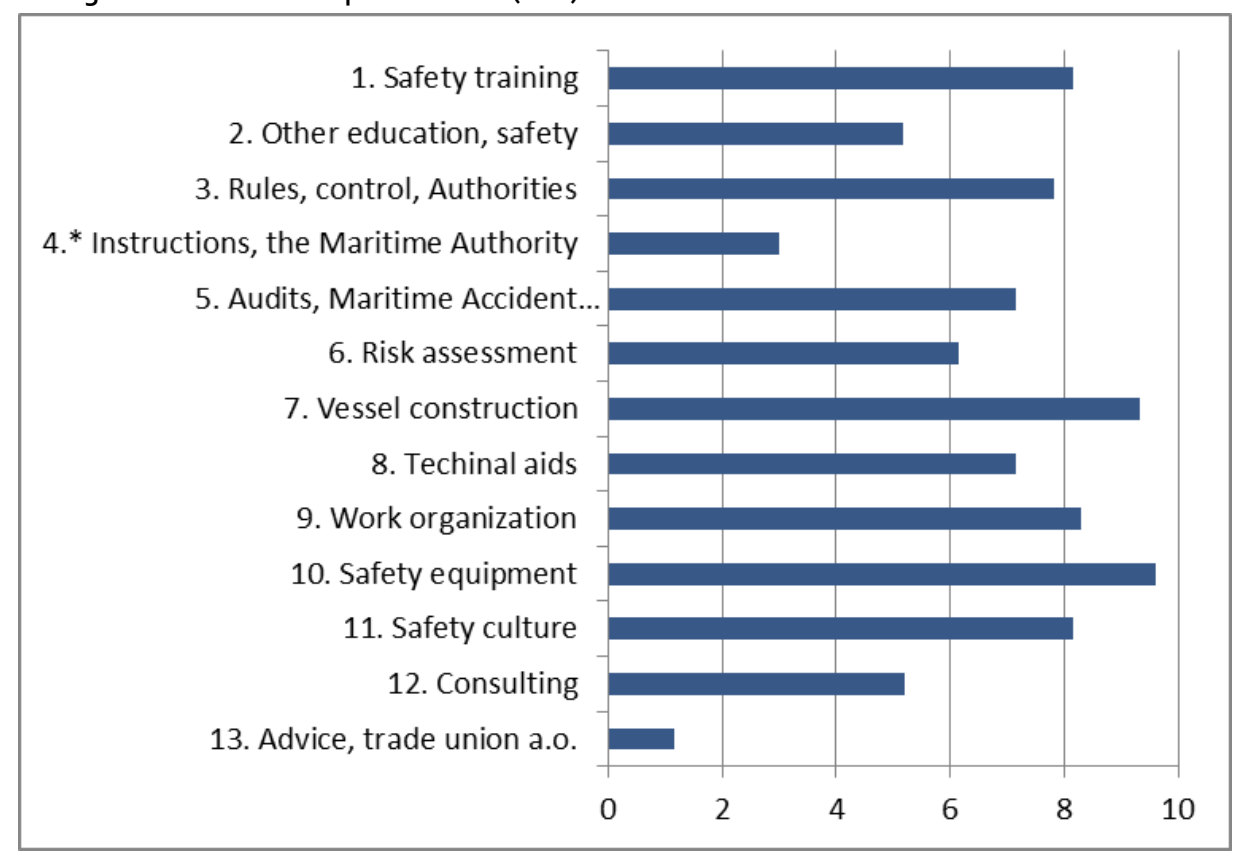

Source: Interview of 6 Icelandic fishermen.

The measures for the prevention of occupational accidents that get the highest assessment from the interviewed fishermen include factors relating to the construction of the vessel, physical layout and safety equipment carried on board the vessel. Safety training, safety culture and the way the work on board is organised are other factors that score above 8 according to the fishermen's assessment.

The six seamen interviewed have all received the safety training that is mandatory for fishermen and is repeated every five years. This training is considered by all to be extremely important, but those from smaller ships mention that the training is better suited to the bigger ships. This training is considered to be of crucial importance. Other safety education is through formal education, or is taught by senior crewmembers. The safety inspection of the boats is considered important when done by an independent authority.

In general, there is a lack of formal guidance regarding safety, especially for the smaller boats. 
Research by the Icelandic Transportation Safety Board - Maritime Division is considered by those who know about it as crucial, but results or information from it need to be better distributed and also more detailed.

Formal occupational risk assessment is known about and practised on a few of the bigger ships, but not on the smaller vessels. The safety culture is generally considered to be high amongst crewmembers, and the construction and layout of the boat are considered to be of crucial importance for occupational safety and health onboard.

In general, they feel that other land-based consultants and the fishery do not understand the risks involved at sea. Additionally, they consider that the unions need to focus a lot more on the topic of safety amongst fishermen.

More general awareness also needs to be placed on safety at sea, but the safety training that they receive and is mandatory for fishermen is of utmost importance.

\subsection{Summary}

The group of fishermen interviewed were all very knowledgeable about the risks involved in being a fisherman in the North Atlantic. They were appreciative of the importance of safety training and having that repeated on a regular basis. They also stressed the importance of safe ships and a safe work environment, including the importance of having access to all available safety equipment, up-to-date weather forecasts and ensuring that the crew is rested. Additionally, there was concern among them that they are today facing the risks involved at sea without the necessary understanding and support from those on land. 
Figure 9: A new safety culture has developed in the fishing industry

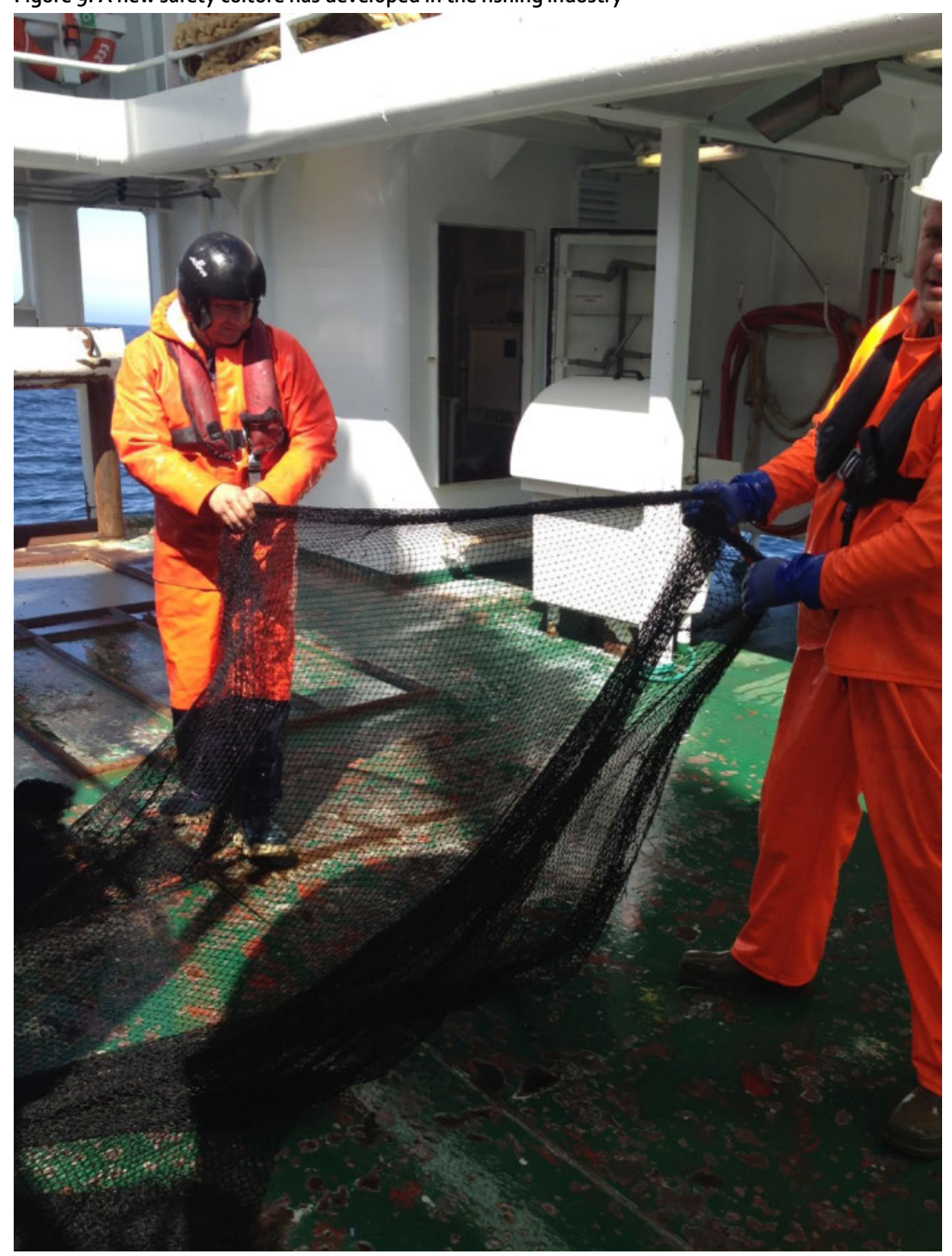

Photo: Thorgeir Baldurssson. 


\section{Denmark: The fishermen's view - Measures taken to prevent accidents in the Danish fishery}

Authors: Jørgen Møller Christiansen and Sarah Rettig Hovmand Centre for Maritime Health and Society, University of Southern Denmark.

\subsection{Introduction}

In Part 1 about Denmark, we explained the historical developments and initiatives as seen from the surrounding factors and institutions. The following focuses on how the fishermen themselves experienced the developments regarding accidents and safety in their industry. The fishermen provide their experiences and we present their evaluation of what they perceive to be important and what has contributed to the prevention of accidents at work.

\subsection{The background for the interview survey and portrait of the interviewed Danish fishermen}

In the pilot project, the interviewed fishermen were drawn on the basis of several criteria, including the common criterion of the participating Nordic countries, namely that the fishermen must have at least 10 years experience. In addition, the Danish study selected fishermen on the basis of reported occupational accidents in the period 19972016. All vessels with more than 12 reported accidents were selected - a total of 18 vessels, all of which were fishing with trawl. This extraction criterion aimed to ensure that the vessels had experienced accidents and, if possible, had experience with the application of measures to prevent accidents. Six of the selected vessels had terminated their activities, or were sold during the period 1997-2016 and were therefore excluded from the survey. The interviews were conducted in week 36 in 2016. Four of the selected ves- 
sels were actively fishing during the study period and were therefore replaced with interviews of other experienced and active fishermen. One fisherman refused to participate. With that background, 11 fishermen were interviewed who have all fished for many years, an average of 28 years.

After the selection criteria resulted in the choice of vessels, the skippers of the vessels were interviewed. One of the vessels has a length of 14.9 metres, eight of the fishermen were skippers on medium-sized vessels (24-35 metres in length), and two were skippers on a vessel over 40 metres. The selected vessels were fishing with trawl and one with fly-shooting. All interviewees were fishing off the west coast of Denmark and had their homeports in Hvide Sande, Thyborøn and Hanstholm. 10 vessels were catching fish for consumers and one was catching fish for industrial use. Including the skipper, the crew on board ranged from 3 to 8 fishermen, with 4 to 5 fishermen being the most frequent crew size. The majority of the vessels had apprentice(s) on board.

The oldest vessel was built in 1973, but most were built in the period from 1999 to 2008. Since the construction, the vessels have undergone renovations and outbuildings, some of them several times. There was a vide variation in how long the interviewed skippers had been on the current vessel, ranging from 3 to 19 years.

Typically, the fishermen went fishing for a week at a time, after which another crew took over, possibly with a certain overlap, so that the vessel was actively fishing for most of the year.

Figure 10: The catch of shrimps is kept fresh by icing

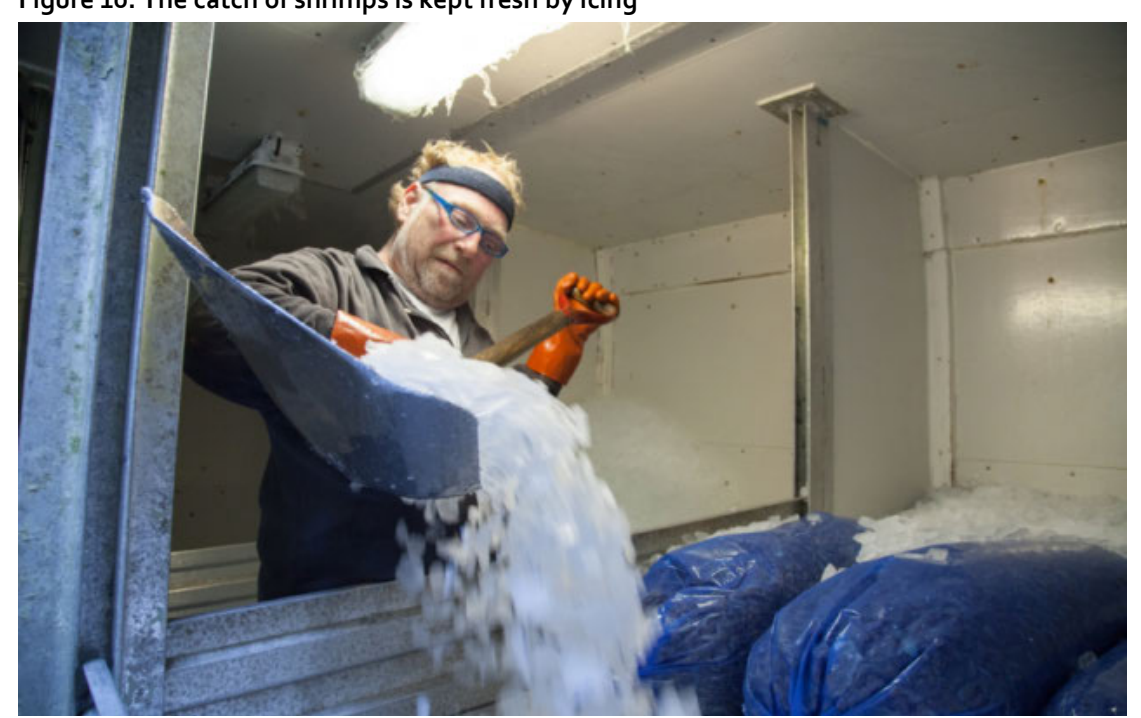

Photo: Michael Yde Katballe. 
The composition of the study has an overrepresentation of skippers, large vessels and fishing off the west coast of Denmark. The same applies to fishing with trawl. However, studies have shown that the serious accidents in fishing occur during trawl fishing, on larger vessels and when fishing off the west coast (Opklaringsenheden, 2006; Christiansen, 2016; N). Consequently, the material reflects the special accident risks that apply to the Danish fishery in a reasonable manner. Ten out of the 11 fishermen interviewed are fishing for consumer use, which is a coincidence rather than a consideration made while selecting the fishermen participating in the study. Unfortunately, only skippers and no ordinary fishermen/employees participated in the interviews. So the interviews reflect the perspective regarding the development in accidents as seen from the leader/skipper's point of view, which is also interesting because, according to the Working Environment Act, the skipper has the responsibility to ensure that the work is performed safely and without risks to health.

\section{3-2.1 The fishermen's experiences with accidents}

As mentioned, the selection criteria should ensure that the vessel had experience in working with accidents. The interviews confirm this.

The following will focus on the fishermen's reflections about the developments in the fishery regarding the occurrence and prevention of accidents. What has worked?

\subsection{The fishermen's views about measures to reduce accidents in fisheries}

The interviews lasted between 23 and 53 minutes and were conducted as telephone interviews, and in eight cases through face-to-face interviews. The interviews collected background information about the fishermen (see above), and in addition, special attention was paid to measures that might possibly have contributed to the prevention of accidents in fisheries.

The average score of the 11 fishermen's responses was calculated and illustrated in Figure 11. The blue bars illustrate the average. The Figure provides abbreviations of the questions. The full length of the questions is found in Chapter 8.1 
Figure 11: Denmark. Assessments of the relevance of 13 listed ways to promote occupational safety in fishing. The fishermen's response. Mean. Ranked. $(\mathrm{N}=11)$

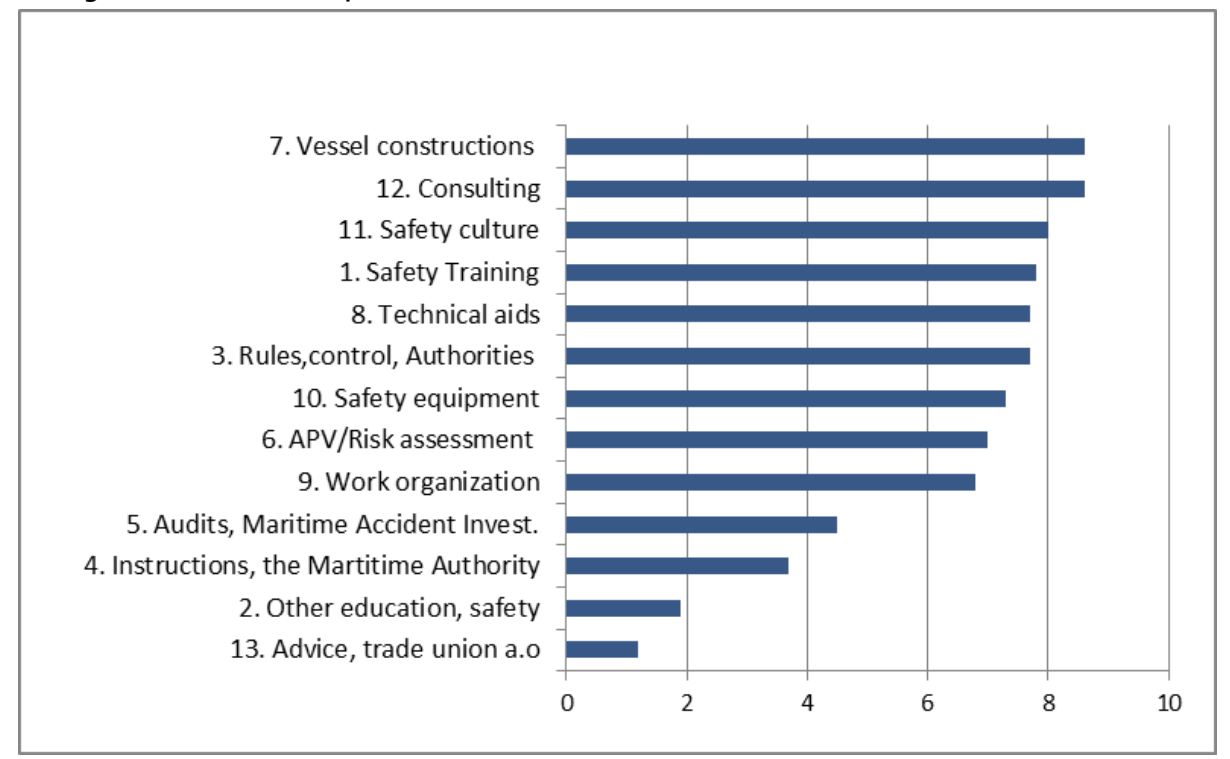

Source: Interview of 11 Danish fishermen.

In question 5: "Investigation and recommendations from the authorities, e.g. the Danish Accident Investigation Board" the answers range from o to 9, and so the answers are divisive. A high assessment of this question indicates that the respondents mean that the reports sharpen the focus on areas about which the fishermen should be particularly aware in order to improve safety on board. One fisherman said the following: "Well, yes, certainly I think it is fine to see the outcomes of incidences at sea. We should of course learn form others' mistakes. And I read them too! So it can get a $7 . "$

Another fisherman agreed, and added that a change had taken place compared with earlier: "In the past we said: He is hurt and then we did not take it any further. Today we talk about it, and the Danish Maritime Accident Investigation Board tells us where we need to be careful."

Several fishermen acknowledged that they did not spend time reading the reports, and that they were not discussed by the crew. One fisherman justified it as follows: "I just think that in general we have been much better at talking about risk areas on our own vessel. We do not read that much." Others did not spend time reading about accidents which they had not been involved with themselves, and some highlighted that the vessel and the risk areas differ considerably from vessel to vessel, and therefore it might be difficult to apply the reports. 
Regarding other questions, the responses are far more coherent, such as for instance in question 7: "The construction and physical layout of the vessel", where the answers are between 8 and 10. This question also represents the best rating overall, due to the highest average score and the lowest deviation. The fishermen agreed on the importance and impact of new ships regarding the decreased rate of accidents and improved safety. The fishermen acknowledged that safety measures are considered during the construction of modern fishing vessels, taking previous experience into account in the design process. Several of the fishermen even thought that this was the most crucial factor leading to the decrease in accidents. One fisherman said: "the more modern, the better the safety. And it is also because - if I were to build a new boat, then I would also bring in all my previous experiences I have had from the ships that I have sailed with. For example: No German pull today, forget it, get a Skagen gantry crane - a travelling gantry instead."

Nine of the questions resulted in answers that are positioned above average - five or more. This applied to: $1,3,6,7,8,9,10,11$ and 12 .

In question 1: "Safety training in fisheries", most of the fishermen regarded safety training as one of the most crucial factors, and therefore rated this question as a 10. One of the fishermen said: "Yes, it is very important, 10. To teach people about dangers is the most important factor. For example, one should not go near the blades and so on. It is important that you tell people about those unforeseen things that can happen like a swinging wire. You must consider it and also take it easy. I often go out on the deck and talk about it." Others were also positive regarding the safety training that the fishermen's apprentices receive during their education today. They believed, however, that they lacked practical experience. One fisherman expressed: "I will give it 7. If it should be higher it should be more practical. They are obliged to participate in safety training during their education, but at the school they get on a ship that is not suited for fishing. It is very good that they learn seven times to put on a lifejacket, but the practical part is missing where not to stand and where you can be slapped over your fingers and so on." Some fishermen believed that the more experienced fishermen were just as safety-conscious as those who had received courses in safety training. Others clearly thought that young people were more safety-conscious than the elderly.

In question 3: "Rules, auditing and controls by the authorities on safety and prevention in fisheries", the ratings are between 5 and 10 . Most of the fishermen regarded controls as crucial because they force the fishermen to relate to safety on board, and so rules, supervision and control have had an important value regarding the increased safety. There were also critics among the fishermen involved: "They can get 6 . They do not come all the way around. The controls are too much uneven and not thorough enough. When we are working with the APV for instance, they do not look at the content. They just make 
sure that it is made. They could also look more at trawls and blades; they are more concerned about all the fixed equipment, e.g. counter weights, hatches and stuff-. What I think is the most dangerous to work with is gear and work with blades - and that they do not care much about." Another pointed out the stability of the vessel, since they were aware that the stability test was not always carried out properly when changes and modifications to the ship had been made: "A new test has to be made, but some people do not do the test, and their documentation is not always correct."

In question 6: "Use of workplace assessment onboard the vessel" (APV), there is a certain deviation in the responses. Most respondents regarded APV to have had a major impact, and justified it as follows: The APV sharpens the attention towards dangerous areas, permits a dialogue about safety on board, and it is useful for training in safety when a new crewmember joins. Despite the fact that most fishermen regarded APV as a good tool, some of the fishermen argued that it could not function without daily communication, and they were convinced that the communication about safety was far more important: "I am more concerned about seeing what they do on board, and then tell them if they do something wrong. New men on board are, for example, never allowed to work with the drums and the blades. These are the most dangerous we have. And if they are allowed, they get a thorough instruction and work together with an experienced fisherman." The fishermen who scored below average were for instance justifying it with the fact that they did not really use it, and one of the fishermen did not even think that his crew had read it.

In question 8: "Technical aids on board to reduce workload, e.g. lifting gear", one fisherman rated five and the remaining gave above average. They were all positive about the equipment that is available today. One industrial fisherman said for instance: "/t has plenty to say. When I started fishing, all we had was a cleaning conveyor belt. Today the fish come to us and run directly to the hold. We do not need to drag around and we have a crane on board. We have all sorts of things." And with a twinkle in his eye he added: "The crew must almost smear udder cream on their back so they do not get bedsores!" Other equipment was also mentioned: Rope management system, safety boots, helmets (some with headset), anti-slip on deck, sorting machines, conveyor belt, noise reduction, anti-rolling devices and cranes. Many pointed out that heavy lifting had reduced, but there was still room for improvement. Work in the hold was especially mentioned as an existing problem, which was why many demanded crate lifting equipment, but the problem is that few vessels have the necessary space in the hold and lifts are not yet fully developed to be able to commit them to the sea, where there is a lot of movement.

In question 9: "Organisation of work on board. E.g. delegation of tasks, knowledge of what to do and who does what", there is a major deviation. Several fishermen emphasised that communications about safety had considerably increased, and that this had 
had a major impact, whereas others believed that communication had not changed, but had always been good, which is why a lower assessment was given. One fisherman who gave a low score (3) explained this as follows: "It has nothing to do with safety, we ensure that everyone has different responsibilities. It just works, so it does not matter. People always do the same. If a new crewmember comes on board, they will start as a cook; any idiot can manage that."

Question 10: "Safety equipment for the fishermen and the vessel". All fishermen indicated that safety equipment had had a greater impact and rated it to a score of 5 or higher. In addition, personal protective equipment was mentioned, such as non-slip safety boots, lifelines, immersion survival suits and so on. The reason for not scoring 10 on this question was justified with arguments such as: Things can always be better. One fisherman also said that you should probably wear a helmet. Almost all the fishermen traced the point regarding not wearing a helmet. One argued: "We may not use the helmet because it can be damn hot in the summer. But we should do it. It should be mandatory when you unload because an empty box weighs 3-4 kilos and if the box hits you, the helmet can mean a lot. Those who used a helmet, had helmets with headsets so they could communicate better. One fisherman highlighted these helmets: "It is two birds with one stone, it increases safety and it is easier to talk, and then people take them on. If I were to shout from the wheel house, there is a lot of noise, so it can be difficult to hear what I am saying." Some of the fishermen expressed that they were considering buying these helmets.

In question 11: "The safety culture on board", all the fishermen rated above average. They all believed that a change in attitude regarding safety had occurred. Now safety was something that was communicated and worked with continuously, so people did not get hurt. One fisherman put it as follows: "There has been a change in attitude. Not least among skippers (...). It is much better; it has gone from 5 to 10. People are generally starting to think more about safety also when they make a conversion." Another fisherman said: "People are good at saying if something is not working and must be replaced. And then I do so, I do not think about the money. If a bolt is loose, then you should not sail with it. That kind of stuff is important to us." Just a few of the fishermen believed that the older and more experienced fishermen were less attached to the safety culture than the younger fishermen.

All the fishermen were very positive about question 12: "Advice, help and support from consultants, e.g. the Danish Fishermen's occupational Health Service (FA)". They believed that the FA was one of the most important factors regarding the decrease in accidents, because the FA had raised awareness about safety and had been good at advising and guiding fishermen about safety measures. This factor was actually in a shared first place (see Figure 11). One fisherman expressed: "If they were to have a higher grade, they should probably have one more consultant, because Flemming (Manager of the FA) is damn much 
hung up." One of the fishermen even said that he would be willing to make a greater financial contribution, so that more people could be recruited to work in the FA.

Four of the questions have an average score below 5, these are: questions 2, 4, 5 and 13 (see Figure 11).

In question 2: "Other education in relation to fisheries and safety", there was a large deviation represented. This may be explained by the fact that the fishermen were in doubt as to the meaning of this question, as they had already previously answered question 1 , which referred to the importance of safety training in the fishery. All the fishermen interviewed were experienced fishermen who had been in the occupation for many years and started their career as fishermen before the current requirement of participating in a safety course before they could enter their education as fishermen. Therefore, they had almost no previous education in safety and therefore had no real answer to this question. Others mentioned as positive factors the mandatory medical course (medical treatment on board), the course on the medicine chest and the optional management course. All agreed, however, that a course on safety was a good thing, but also stated that experience was crucial for safety. One of the fishermen had had his entire crew participate in an AMU course on safety (labour market training). Another fisherman even thought that it should be mandatory for all skippers to participate in a course about safety.

Question 4: "Guidelines and information from the authorities on safety and prevention in fisheries", also represents a high deviation in responses. This is due to the fact that some of the fishermen were not sure about what guidelines this question referred to. Others did not read them and considered that direct communication and dialogue regarding safety between the Danish Maritime Authority (DMA) and the fishermen during inspections was much more effective and therefore preferable. However, there was also praise regarding the work of DMA and the Danish Maritime Accident Investigation Board, which included the easy accessibility to good safety information when knowledge about something important was needed.

Lastly, it should be mentioned that the lowest rating was assigned to question 13: "Advice and help from others, e.g. trade unions and organisations". The responses made it clear that it was due to the fact that the fishermen did not know what this question included. Some fishermen pointed at the local fishermen's associations, which they believed had been very important in the development of safety. According to the trade union ${ }_{3} F_{1} 7$ they did not think that they had had an impact in any way, since the skippers

${ }_{3}^{7} \mathrm{~F}$ is a union for unskilled and specialised workers, including employed fishermen. 
were never in contact with them. According to the skippers' opinion, they are only relevant in relation to payroll. If we had interviewed employed fishermen, the answers would probably have had a different outcome.

\subsection{The fishermen's view about the future}

The greatest challenges today regarding a further reduction in accidents?

The responses from the 11 fishermen to this question were almost divided into two categories. About half of the respondents pointed to the loads in the hold, where there was still a lot of heavy lifting of boxes with fish. They especially emphasised the need to create crate-lifting equipment. Some of the fishermen had visited the FA's road show, where new lifting gear was demonstrated. One of the fishermen believed that the Norwegians had done something that might be used. The hold on some vessels needed to be reconstructed for the crate-lifter to be used effectively. Cleaning machines and anti-rolling were also identified as a problem. While the anti-rolling would reduce noise, the cleaning machines would make it possible to avoid manual handling and then: "you can maybe cut down on your crew." According to the fishermen, this technical equipment was under development and they were willing to invest in them when they knew that they worked. One of the fishermen assumed that the crate-lifter was one of the things where the fishermen could get a grant from the EU subsidy scheme. Securing the net drum was also identified as a challenge: "Another thing that is dangerous is the biggest net drums, if something begins to fling. The blades can also be a problem. Fixation works fine, but there are many who do not get it, and it is weird because it costs nothing, it is just a piece of iron. But it has something to do with the big trawls because there you cannot do it-yet!"

The other half of the fishermen found that answering the question was rather difficult and justified it as follows: "We have few accidents and I cannot see how we can get it further down." Another answered: "I think that we address the problems fairly well when they occur, the accidents are treated in HSU (the local port safety committee) and this is a very good help." Another fisherman pointed out that it was a problem that accidents were only dealt with after they happened and suggested that fishermen should be better at reporting "Near Misses" in the electronic Safety Management program, which the FA had developed. That would be a way to share experiences with other fishermen and to develop safety measures before an accident strikes. It was also suggested that practical tests could be made in order to react before an accident hit, as described in the FA's guide. The Safety Management program would also be an efficient tool, because the program allows you to document each time you make an exercise and you can program it to send out a reminder about when the next exercise is going to be conducted. 
An example of an important prerequisite for better safety was illuminated by one of the fishermen: "The economy must be in order for the safety to be in order, so it is crucial that the prices on fish are now rising - in that way you can also invest in safety."

\subsubsection{Good advice}

At the end of the interview, the fishermen were asked the following question: If you were approached by a colleague who would like to hear your advice on what you think is the most important for reducing accidents in the fishery, what would your answer be?

The answer from five of the fishermen was: "Call Flemming! Then you will get the best help." Flemming is the manager of the FA, who the fishermen agree has had a great impact regarding the positive developments in the work environment and in the incidence of accidents (question 12). Other more concrete advice was also given. One fisherman reiterated his previous advice: "Look at the rope management. Get it fixed, so the blades are not dangling. We have done that. It is a great sinner, when we talk about accidents." Another fisherman expressed: "Make sure your stuff is in order - if in doubt, make it safe. Use the APV, so everyone is aware of the risks." Other advice was related to the safety culture: "There should be a good communication - have a chat with the crew on what can be done better. The APV can be a good help." One mentioned his own responsibility as skipper: "It is all about communication with employees and making sure to keep an eye on what they are doing, and telling them if they do something wrong, so in other words to apply common sense. Everybody is allowed to take a little longer. Good communication is the most important thing. And watch out for god sake!"

\subsection{Summary and Conclusion}

The fishermen's responses to what they thought had worked in the prevention of accidents and what had reduced the rate of reported accidents so significantly can be summed up as a combination of several factors.

Initiatives have been made that address changes in knowledge and attitudes regarding safe behaviour on board in the form of written guidelines, campaigns and so on, which have been made by the authorities. However, these initiatives seem to have had a limited effect according to the skippers. The safety inspections and controls made by the authorities seem to have had a good and effective role and this has forced the fishermen to keep on working with safety and thereby safety has improved. These types of initiatives have not been the only measures. Other initiatives have addressed the use of safety equipment and personal protective equipment, devices such as gear 
and equipment, non-slip floors, as well as the use of personal protective equipment. These changes have come through because of legislative and structural changes. Something is still missing, but it is clear that these measures have definitely contributed to the increase in safety. An important improvement in line with the above has been safety measures, such as education in safety of new fishermen and training in safety on board, in order to increase awareness and mutual communication about safety on board in connection with the daily work, the use of workplace assessment (APV) etc. All these measures seem to have had a major impact. Guidance, help and support from the FA have undoubtedly been of major importance and have supported the fishermen in their efforts to reduce accidents. Concurrently, the work with safety and the prevention of accidents by the Harbour Safety Committee (HSU) has contributed to an efficient follow-up and an exchange of experiences on applicable solutions regarding the reported accidents. Perhaps the most important safety measures have aimed to change safety standards and improve the safety climate and culture. This has not come as a focused, deliberate campaign, but rather has happened gradually, in line with mutual conversations and communications among the fishermen about what can and should be done with safety, and the fishermen's increased awareness of the risks regarding dangers and accidents in the profession.

International reviews of research into the prevention of accidents illustrate that integrated safety measures have generally had the greatest positive impact on safety behaviour and accidents (Dyreborg et al., 2013). In the fishery, based on the conducted interviews, we find, in all, that an integrated safety approach has happened - an orchestration of efforts, which has led to the decrease in reported accidents in the fishery from a very high level to a level just below the national average regarding reported accidents in Denmark.

The fishermen did have recommendations about further technical changes and improvements, and they had good advice for colleagues to be even more conscious about safety in the fishery, and they remembered to keep up a dialogue with the crew about the risks and what characterises good safety practice. Some of the fishermen were doubtful about the possibility of getting a further decrease in accidents, while others found that essential challenges still remain. Accordingly, they have confidence that the FA will also be helpful and supportive in the future. 
Figure 12: This picture illustrates the importance of an effective emergency service when an accident occurs

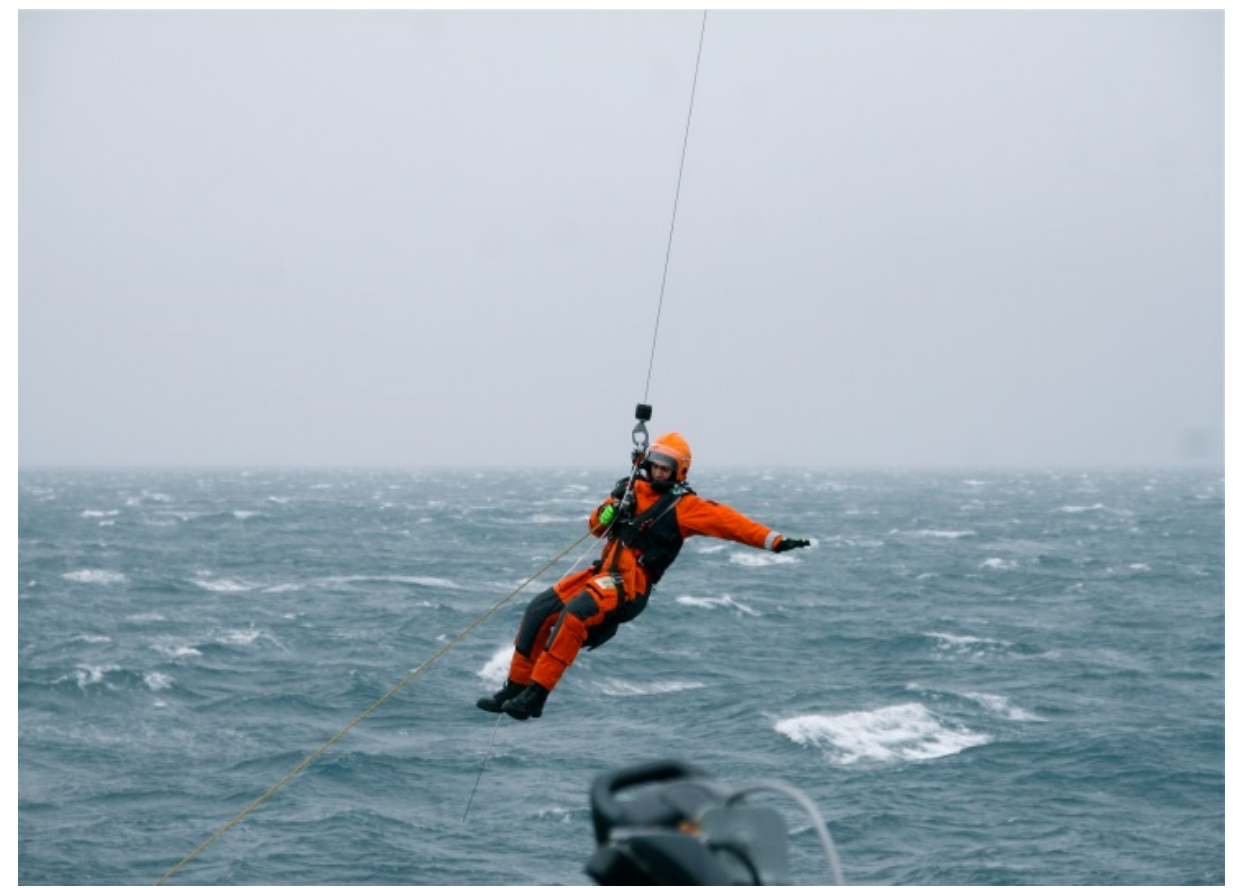

Photo: Aksel á Botni. 


\section{Summary - the Nordic Fishermen's view on preventive measures}

The pilot project consisted of interviews with 47 fishermen from the Nordic countries, who were asked to give their assessment regarding which initiatives have had a preventive impact on working with occupational accidents in fisheries. Only two of the originally selected fishermen refused to participate in the study.

The respondent fishermen in the respective countries reflected the population of fishermen in the specific country reasonably well. However, the vast majority of respondents were skippers, and the ordinary fishermen were underrepresented. The skipper is a relevant respondent because, according to the work environment act for fishermen, the skipper/owner of the vessel has the primary responsibility to ensure compliance with the health and safety regulations.

All interviewees had been in the occupation for several years and therefore had many years of fishing experience. They all fished in both small and large vessels of different types, and had experience with occupational accidents in which they had either been involved themselves, or they had witnessed the accident(s) on board the vessel.

The project used a joint Nordic questionnaire designed to match the purpose of the project. At the beginning of the interview, the fishermen were asked about personal, factual conditions. Afterwards, they responded to structured questions, where the fishermen gave their assessment on a scale from 1 to 10 (low to very important) about what had influenced and worked in the prevention of occupational accidents in fisheries. The respondents subsequently elaborated each question/answer. The interview ended with open questions about the future, regarding what is needed to ensure that accidents in fisheries can be brought down even further.

The following themes about what had influenced the risks and had prevented occupational accidents were studied in the survey. The questions, that were used, were:

1. Safety training in fisheries?

2. Other education in relation to fisheries and safety?

3. Rules, auditing and controls by the authorities on safety and prevention in fisheries?

4. Guidelines and information from the authorities on safety and prevention in fisheries? 
5. Investigation and recommendations from the authorities, e.g. the Danish Maritime Investigation Board?

6. Use of workplace assessment onboard the vessel?

7. The construction and physical layout of the vessel?

8. Technical aids on board to reduce workload, e.g. lifting gear?

9. Organisation of work on board. E.g. delegation of tasks, knowledge of what to do and who does what?

10. Safety equipment for the fishermen and the vesse?

11. The safety culture on board?

12. Advice, help and support from consultants, e.g. the Danish Fishermen's Occupational Health Service?

13. Advice and help from others, e.g. trade unions and organisations?

14. Other? What?

Figure 1: The Nordic countries. Assessments of the relevance of 13 listed ways to promote occupational safety in fishing. The fishermen's response. Mean. Ranked. $(\mathrm{N}=47)$

13. Advice, trade union a.o.

12. Consulting

11. Safety culture

10. Safety equipment

9. Work organization

8. Technical aids

7. Vessel construction

6. APV/Risk assessment

5. Audits, Maritime Accident..

$4 *$. Instructions, the.

3. Rules, control, Authorities

2. Other education, safety

1. Safety Training

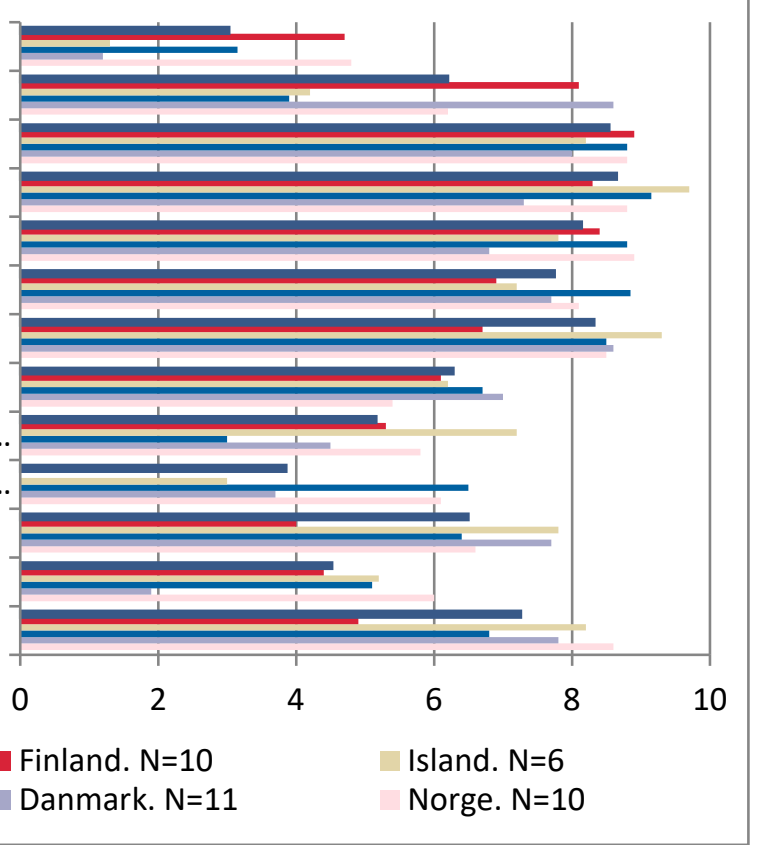

Samlet Norden $\mathrm{N}=47$

- Færøerne. $\mathrm{N}=10$

Danmark. $\mathrm{N}=11$

Island. $\mathrm{N}=6$

*) Question 4: In Finland, there is no corresponding authority that would be responsible for publishing fishery-specific safety guidance, information etc., so the question was omitted in Finland.

Source: Interview of all 47 fishermen. 
In Part 2 of the report, the results from each country are described in detail. Therefore, the summary will instead be focusing on the Nordic region as a whole.

Figure 37 shows the average response from the fishermen on the significance of the above aspects. The red bars illustrate the Nordic countries as a whole.

The fishermen in the respective countries overall had very similar perceptions in terms of what had had the greatest impact regarding the prevention of occupational accidents. However, some variations were also seen:

- In Norway, three aspects got very similar high ratings: work organisation (question 9), safety equipment and safety culture (questions 10 and 11). Then followed safety training and the construction of the vessel (questions 1 and 7 ).

- In Denmark, the physical construction and consultancy achieved the highest rating (questions 7 and 12). Subsequently: The safety culture and safety training (questions 11 and 1 ).

- In the Faroe Islands, the picture is somewhat different: Safety equipment, technical equipment on board, safety culture and safety training (10, 8, 11 and 1).

- In Iceland, as well as in the Faroe Islands, safety equipment was rated highest (question 10). Hereafter follows: construction of the vessel, safety culture and safety training (questions 7,11 and 1).

- In Finland, there were four aspects that stood out with a rating exceeding 8: safety culture, work organisation, safety equipment and consultancy (questions 11, 9, 10 and 12).

- In the Nordic countries as a whole, four aspects got the assessment of 8 or more. This was for: safety equipment, safety culture, construction of the vessel and work organisation (questions 10, 11, 7 and 9). In the opinion of the Nordic fishermen, these aspects were the factors that had had the greatest impact on prevention of occupational accidents. In Denmark, question 12, consultancies, was also at the top as a factor of great importance in the prevention of occupational accidents. Other Nordic countries do not have a similar occupational health service for fishermen as there is in Denmark. This difference seemed to be an important contributing factor to the major decrease in reported occupational accidents in Denmark. 
- In each country, the interviews were completed with the fishermen's views on the future and their recommendations regarding a further reduction in occupational accidents and improved safety. We have chosen to save these views for the final conclusion (see below), where they constitute a part of the overall investigation and collection of the pilot project's results and recommendations that will contribute to the sharing of knowledge and future efforts to ensure a safer and healthier working environment in fisheries. 


\section{Conclusion and recommendations}

So far, the theme of this project has not been studied in the Nordic countries. Funding by The Nordic Council of Ministers has allowed the realisation of this pilot project.

\section{About the project}

The study is based on research-based knowledge and documentation of the trends in occupational accidents in the Nordic countries and on statements on initiatives and measures for the prevention of accidents in fisheries by the authorities and other agencies. Furthermore, a joint Nordic interview survey of the fishermen in the Nordic countries has been conducted with focus on their assessment of issues that have had an impact and have shown to be effective in the prevention of accidents in fisheries.

The project has been executed in a collaboration between research institutions in Denmark, Norway, Finland, Iceland and the Faroe Islands. The project could not be realised without the benevolent assistance of the interviewed fishermen, authorities, institutions and other stakeholders in the Nordic countries.

It was the aim of the project to study the trends in occupational accidents/injuries in the Nordic countries. In this context, an occupational injury is understood as an injury that occurs due to the fisherman's work or working conditions.

\section{Contents of the report}

The report is divided into two main sections: The first section presents the trends in occupational accidents in the respective countries, as well as the preventive safety measures launched in the Nordic countries. The second section describes and analyses the conducted interviews of the fishermen in the Nordic countries, with a focus on the fishermen's own evaluation and assessment of the preventive measures and their effect. The pilot project, the interview survey of fishermen in the Nordic countries, includes 47 respondents: It was found that the selected fishermen/respondents covered reasonably well the key characteristics of the fisherman population in the investigated countries, so that their statements can be used for providing an indication of trends. However, a larger study will obviously give a more valid and reliable basis for conclusion. 
The following conclusion aims to link the two parts of the report together and to summarise the fishermen's assessment of the preventive measures and their effects. On this basis, we present recommendations on further efforts that can improve safety in fisheries.

\section{The analysis of occupational accidents in the Nordic countries}

- The regulation of safety and health in the fishing industries in the Nordic countries follows international legal regulations, in particular regulations from the IMO and/or EU. In all the Nordic countries, an increased attention on fisheries and safety developed in the 1980 s and 1990 .

- Accidents must be notified to the authorities in all countries. The report describes the development in each country studied. We have shown that national rates for the occupational injury and fatalities in the Nordic fishing industry cannot be compared directly, because the basis for the collection of reliable injury data varies from country to country.

- For the first time, analyses have been conducted of developments in occupational accidents in the Faroe Islands. Based on all the analyses, the trends in the development can be seen as valid documentation regarding the effects of the interventions in the Nordic countries. These data will now be presented.

- Danish analyses of reported accidents in land-based industries have estimated that only about half of all notifiable occupational accidents are being reported (Lander et al., 2012). In fisheries, the underreporting is undoubtedly also substantial. This underreporting is illustrated, for example, in the Faroese data from The Faroese Maritime Authority, which has very few reports. Instead, data from The Faroese Accident Insurance Counsel are used in this report. The extent of underreporting in the Nordic countries as a whole has so far not been investigated, but such an investigation would be useful in order to better monitor developments in this area.

- From a preventive perspective, reports of accidents are an appropriate and relevant instrument. The project highlights the need for the establishment of harmonised reporting of injuries in the Nordic countries, in order to compare developments in occupational accidents between the Nordic countries on a valid basis. 


\section{Fisheries, crew and safety}

- The fisheries' economic importance in the Nordic countries is essential, especially for the Faroe Islands and Iceland. The number of fishermen in several Nordic countries has approximately halved over the past 15 years, but the total amount of fish caught is almost the same, or has increased. For example, in Finland the catch of fish has grown $25 \%$.

- The average age of fishermen in the Nordic countries is increasing - so it is important to attract new recruits to the sector.

- The data from Denmark show that the age of the fleet is high and increasing. There seems to be a need for the construction of new fishing vessels. Many of the existing vessels in the Nordic countries, however, have been continuously modernised. Information from several fishermen in the interview survey indicates that new constructions will improve safety. The number of shipwreck and other maritime disasters in the Nordic fishing fleet has decreased remarkably. Several factors have had an impact on this favourable development. Information, e.g. from Iceland, identifies that the significantly improved weather reports at sea are an important determinant for vessel safety. Measures for improved stability of the vessels, as has been emphasised in e.g. Denmark, are other factors that have minimised fishing disasters at sea. Vessel construction, safety equipment and modernisation of the fishing fleet were assessed by the fishermen as overall being important explanations for the decrease in accidents.

\section{Occupational accidents, safety and prevention}

- The study shows an overall reduction of the number of reported accidents. This reduction appears to be particularly significant in Denmark, Norway and Iceland, but the number of accidents in the Nordic fishing fleet is still considered to be too high.

- In the Nordic countries, a special focus on workplace risk assessments on board has been implemented during the last several years, and has included the prevention of disasters for small vessels, such as improving vessel stability and life rafts. In Finland, workplace risk assessments are voluntary. They are included in the occupational health services, but only $15 \%$ of the fishermen have chosen to join the service. 
- Many accidents occur on small fishing vessels. In Norway, the majority of workrelated deaths happen in the coastal fleet. In several Nordic countries, the authorities have turned their major attention to the safety of the smaller vessels. The report's analyses show that awareness of prevention should also be directed towards larger vessels, in particular the trawlers, which in the Danish analysis was shown to be a high risk area in relation to reported accidents, not least in relation to the serious accidents.

- The Danish data show that the serious accidents in fisheries do not occur as expected during work in bad weather conditions, but rather in reasonably good weather. The prevention potential is therefore greater. The Danish data on reported accidents also show that new or newly-employed fishermen on the vessels have a significantly increased risk of accidents compared to crewmembers who have been on board the vessel for a while. The Danish fishermen stated that the attention to training and instruction of new crewmembers on board has been tightened.

- The interview survey suggests that occupational accidents seem to be a more common part of the Faroese fishermen's work life than is the case in the other countries. This observation is based on relatively few people. A major representative survey is necessary for further clarification.

- The technical safety equipment for machines and personal safety equipment on board in the Nordic fisheries has experienced a positive development, and according to the fishermen this has been a very important and contributing factor to explain the decreased number of accidents. The interview survey, however, shows that there is room for continued improvement.

- Common to the Nordic countries is that the authorities have focused on regulation, control, information and safety training to reduce the number of accidents, and that in general the fishermen regard these initiatives as positive factors.

- Denmark and Finland has an occupational health service for fishermen. The Finnish service was established 32 years ago, but is not as widely used as the Danish one (see Chapter 8). The Danish service, called the Fishermen's Occupational Health Council, has provided multifaceted information and great practical assistance to the fishermen since the late 1990s. The fishermen greatly appreciate this service and consider it a major contributing factor that can explain the reduced number of accidents. The Danish Maritime Authority in Denmark and the Danish Fishermen's Occupational Health Service operate in close cooperation, including with the follow-up on reported accidents, where Harbour Safety 
Committees constitute a system that seems to greatly promote the targeted efforts for the prevention of accidents.

- In Denmark, the Danish Fishery Occupational Health Council has developed and implemented an e-based Safety Management System, which is currently implemented and used in Denmark, Greenland and Scotland. Norway has applied The Norwegian Compliance Survey Risk Assessment ("FiskRisk.no"), as an offer to fishermen. Appointed health care centres in Finland offer fisheries an Occupational Health Service. This service comprises both regular workplace visits I safety checks (repeated every 4 years) and health checks (recommended every 1-2 years). Due to various reasons, only about $15 \%$ of the fishermen have chosen to use this service.

- Some of the fishermen's assessments of the investigated preventive factors were modest. This applies to the Fishermen's Associations initiatives regarding safety, which was assessed by the fishermen in all countries to be of minor significance. Another factor that in the fishermen's opinion was of minor importance was the guidelines and information from e.g. the Danish Maritime Authority on safety and prevention of accidents in fishery. In Finland, there were no specific guidelines in relation to the fishery; in the other Nordic countries, the typical justification from the fishermen for their low assessment was either that they did not know them or did not read them.

\section{Safety culture}

- According to the fishermen, the safety culture has improved significantly typically the entire crew takes safety and safety behaviour seriously.

- The involvement of all stakeholders - the authorities, the vessel owner and the workers - provided good conditions for conducting an efficient safety culture and safety behaviour.

- Written materials, guidelines and information may be good, but were rated low by the fishermen. According to the fishermen, direct dialogue with the target group seems to have greater impact and promotes the desired goal better.

- To have the best conditions for a strong and effective safety culture requires the skipper to take the lead, to be involved and to make the crew aware of their responsibility concerning safety and safety behaviour, including ensuring the instruction of new crewmembers on board in safe behaviour. 


\section{Education and safety}

Training of fishermen in safety is established and developed in most Nordic countries. In Iceland, the Maritime Safety and Survival Training Centre was launched in 1985 and initially provided safety courses as a voluntary option for fishermen. In Norway, safety training for fishermen has been mandatory since 1989, and a little later similar training became compulsory in Denmark and the Faroe Islands (1997). In Finland, safety training are mandatory for the crew of the big ships, but fishermen in small boats are not covered.

The training in the Nordic countries provides prevention measures to promote safety and health, and in all countries except Denmark and Finland, refresher courses are required after $3-5$ years. In Denmark, it is a requirement that all new fishermen must participate in a safety course before they can enter the profession. The fishermen's assessment of safety training and education shows that it has been an extremely important element in the prevention of occupational accidents and in promoting safety in general.

\section{The fishermen's suggestions for improved safety}

The fishermen had many suggestions for improved safety. Their suggestions were related to training and education on board, safety equipment, design of vessels and layout of the deck as a workplace where safety should be integrated in the technology, organisation of work and ensuring good work routines, attitudes and a better safety culture, better communication between the crew, conducting regular risk assessments, and control and inspections. There is still a lot of heavy lifting of boxes with fish, and several fishermen emphasised in particular the need to create a box lifter in the hold. The vessels' stability was another recurring theme. Many vessels still do not have stabilisation tanks. Fatigue being a problem was especially expressed by fishermen in Iceland and the Faroe Islands. Some of the older vessels are worn out, and so a better economy that permits the introduction of modern vessels will be a path to better safety in general.

\section{The future}

The text above highlights a number of themes that can be the basis for further investigations and can be used for further prevention of accidents in fisheries.

The fishing has shown that it is possible to break the negative curve for accidents at work in the sector. An important question for the future is how the fishermen are 
being informed and involved, so the message is held and their involvement in the prevention of occupational accidents continues to be developed. Direct communication is effectively, and guidance, help and assistance to fishermen are also central issues. It can be argued that a consulting function - such as the Danish Fishermen's Occupational Health Service - is important. Therefore, the other Nordic countries may benefit of a similar service.

The development regarding the trend of occupational accidents amongst fishermen in Finland calls for change. The changing step could be that the Occupational Health Service should be made more attractive and easily reachable to small scale, selfemployed fishing entrepreneurs who fish alone in remote locations. Otherwise, this target group seems to remain outside most occupational safety initiatives. Regular and professionally-competent cooperation between the single fisherman and the Occupational Health Service could probably prevent many injuries and mental problems, and assist the fisherman to maintain good working ability.

In 2016, The European Fisheries Fund has surprisingly not allocated funds directly to safety and the prevention of accidents in the fisheries in the Nordic countries. This may be justified by the fact that things are going well, so that further support is not needed. However, it is important not to lose the momentum that fisheries have in the area, and so hopefully this practice will change in the future.

Highlights from this report may hopefully be an inspiration and used by countries outside those Nordic countries that have contributed to this study. This applies, i.a., to the neighbouring countries in the Baltic Sea, where the latest report from Baltic Sea Advisory Council Secretariat (2014) shows that countries can still learn a lot from each other in order to promote safety in fisheries.(S). 
Figure 1: Life as fisherman has many attractions

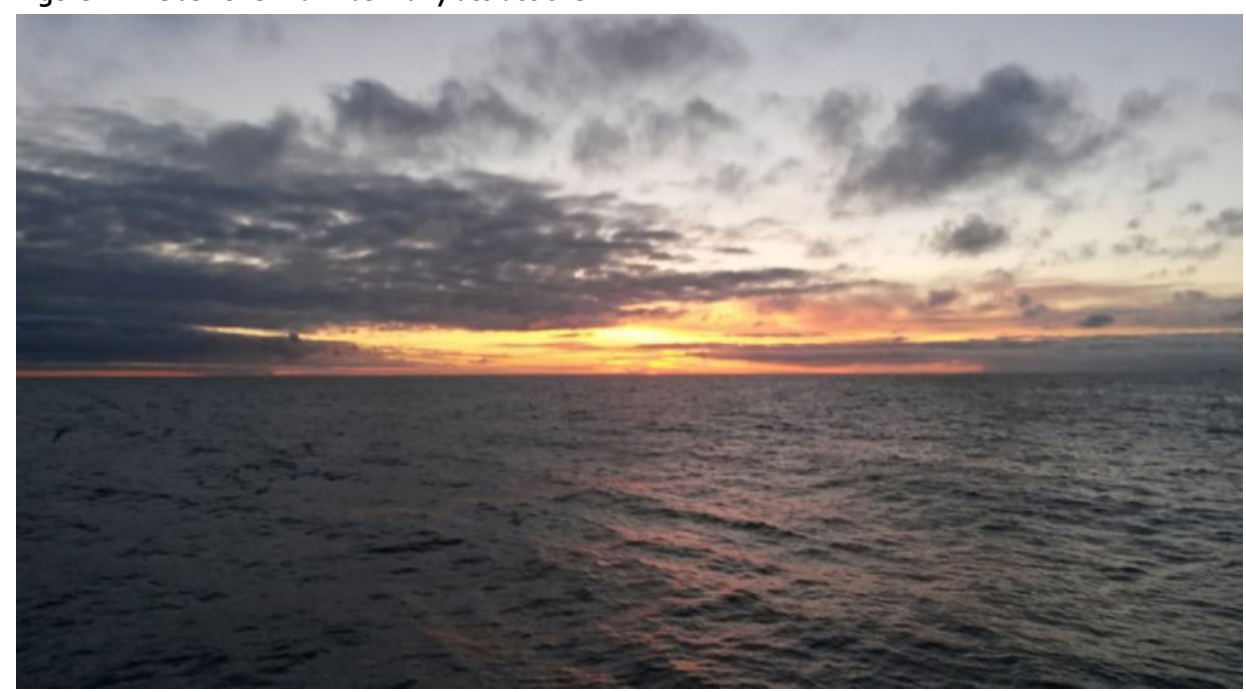

Photo:: Annbjørg á Høvdanum. 


\section{References}

Aasjord, H. L. and Holmen, I. M. (2015): Personulykker og årsaksforhold i den norske fiskeflåten. Sikkerhet i Norske Farvann. P. 6o-84. In Antonsen, Kongsvik, Trond. Oslo. Gyldendal Akademisk.

Aasjord, H. L., Holmen, I. M. and Thorvaldsen, T. (2012): Fiskerulykker og årsaksforhold. Analyse av årsaksforhold ved dødsulykker og alvorlige personskader i norsk fiskeri. Trondheim, SINTEF. Fisheries and aquaculture.

Arbejdstilsynet (2016). Nyhedsbrev. 1. Januar.

Christiansen, J.M. \& Carlsbæk, A.B. Omvæltninger og det psykiske arbejdsmiljø i fiskeriet - i ord og tal. Center for Maritime Sundhed og Samfund, marts 2015.

Christiansen, J. M. (2015): Fiskerne der forsvandt. P- 75.99. In Sjæklen, Årbog for Fiskeri- og Søfartsmuseet i Esbjerg. With English summary.

Christiansen, J. M. \& Bruus Pedersen, J. (2016): Arbejdsulykkesstatistik i dansk fiskeri 1997-2015. Unpublished.

Christiansen, J.M. and Østergaard, H. (2016): Arbejdsulykker i dansk fiskeri-Udvikling og initiativer. Center for Maritim Sundhed og Samfund. In press.

Dyreborg, J., Nielsen, K., Kines, P., Dziekanska, A., Frydendall, K. B., Bengtsen, E., and Rasmussen, K. (2013): Review af ulykkesforebyggelsen - review af den eksisterende videnskabelige litteratur om effekten af forskellige typer tiltag til forebyggelse af arbejdsulykker. Det Nationale Forskningscenter for Arbejdsmiljø. København 2013.

Fiskeriets Arbejdsmiljøråd (2000): Ulykker til søs 1999.

Grøn, S., Rasmussen, H. B., Poulsen, T. R. and Christensen, F. N. (2014): Sikkerhed i fiskerierhvervet. TeamArbejdsliv, Center for Maritim Sundhed og Samfund og Fiskeriets Arbejdsmiljøråd. Esbjerg.

Høvdanum, A. S., (2016). Analysis of Occupational Accidents Reported to The Faroese Accident Insurance Counsel in the Period 1972-2014, with the aim to describe the injury rate trends, to compare the risks in different strata in order to map prevention strategies. Not Published

Høvdanum, A. S., Jensen, O., Petursdōttir, G. and Holmen, I. M. (2014): A review of fatigue in fishermen: a complicated and underprioritised area of research. P- 166-172. Int Marit Health 65 (3). https://doi.org/10.5603/IMH.2014.0031

Håvold, J. I. (2010): Safety culture aboard fishing vessels. P. 1054-1061. Safety Science 48 (8).

Jensen, O.C.: Work related injuries in Danish fishermen. Occup.Med. vol. 46, No.6, pp. 414-420. 1996- https://doi.org/10.1093/occmed/46.6.414

Jensen O. C., Petursdóttir G., Holmen I.M., Abrahamsen A.S., Lincoln J. A review of fatal accident incidence rate trends in fishing. Int. Marit Health 2014; 65: 1-6.

https://doi.org/10.5603/IMH.2014.0011

Jepsen, J. R., and Christiansen, J. M. (red.), (1988): Søfarts- og fiskerimedicin. Sydjysk Universitetsforlag. 
Joensen, H. D. \& Weihe, P.: Yrkisvanlukkur i Føroyum 1975-1979. I: Fródskaparitid 31. bók (1983), si. 104-110.

Kaustell, K. O., Mattila, T. E. A. and Rautiainen, R. H. (2016): Occupational injuries and diseases among commercial fishermen in Finland 1996-2015. P. 163-170. International Maritime Health 67 (3). DOI: $10.5603 / \mathrm{MMH} .2016 .0031$

Kaustell, K. O., Heiberg, A. M., Mattila, T. E. A. and Rautiainen, R. H. (2014): Health, Safety and Environmental Competence Among Fishermen in Botnia and Nordland. http://hseforfisheries.weebly.com/

Lander, F., Nielsen, K., Rasmussen, K. Lund, T., and Lauritsen, J. (2012): Hospital Rapportering af arbejdsulykker til Arbejdstilsynet og registrering af arbejdsulykker i skadestuen på Odense Universitetshospital. En analyse af rapporteringsgraden af anmeldelser for arbejdsulykker til Arbejdstilsynet. In Øje på arbejdsmiljøet. LO-Danmark.

Lindøe, P. H. (2007): Safe offshore workers and unsafe fishermen - a system failure? P. 26-39. Policy and Practice in Health and Safety 5 (2).

Lindøe, P. H., Engen, O. A. and Olsen, E. O. (2011): Responses to accidents in different Industrial sectors. P. 90-97. Safety science 49 (1). https://doi.org/10.1016/j.ssci.2009.12.007

Mäkinen, T. (2015): Occupational accidents in commercial fishing. Turku University of applied sciences. Bachelor's thesis.

McGuinness, E. and Utne, I. B. (2014): A system engineering approach to implementation of safety management systems in the Norwegian fishing fleet. P. 221-239. Reliability Engineering \& System Safety 121 (o).

McGuinness, E., Aasjord, H. L., Utne, I. B. and Holmen, I. M. (2013): Fatalities in the Norwegian fishing fleet 1990-2011. P. 335-351. Safety science 57 (0).

McGuinness, E., Aasjord, H. L., Utne, I. B. and Holmen, I. M. (2013): Injuries in the commercial fishing fleet of Norway 2000-2011. P- 82-89. Safety Science 57 (0).

Mið \& Magn (2016) no. 29. http://fsn.fo/10_MIDogMAGN/Blad_29.pdf

Opklaringsenheden (2006): Temaundersøgelse. 28 arbejdsulykker med spil og redskaber i danske fiskeskibe 1998-2005. Søfartstyrelsen, December.

Salmi, P. (2005): Rural Pluriactivity as a Coping Strategy in Small-Scale Fisheries. P. 22-36. Sociologia Ruralis 45. https://doi.org/10.1111/j.1467-9523.2005.00288.x

Sigvaldason K., Tryggvason F., Petursdottir G., Snorrason H., Baldursson B., and Mogensen B. (2010): Fatal accidents and non-fatal injuries amongst seamen in Iceland 2001-2005. P. 29-35. Icel Med $\mathrm{J} 96$.

Søfartsstyrelsen (1998): Ulykker til søs 1997.

Thorvaldsen, T. (2013): The importance of common sense: How Norwegian coastal fishermen deal with occupational risk. Marine Policy. https://doi.org/10.1016/j.marpol.2013.02.007

Thorvaldsen, T. (2015): Managing risk in the Norwegian fishing fleet. Policy and Practice in Health and Safety 13 (1). https://doi.org/10.1016/j.marpol.2013.02.007

Weihe, P., Joensen, H., and Zachariassen P.: Occupational Accidents Reported to The Faroese Accident Insurance Counsel in the Period 1975-1979. Not published. 


\section{Internet}

The Faroe Islands Fisheries Inspection. www.vorn.fo

The Faroese Fisherman Union www.ff.fo

Faroese Maritime Authority. www.fma.fo

The Norwegian Maritime Authority. Website for occupational fishermen. www.yrkesfisker.no

Reports of Severe Accidents to Faroese ships. http://fma.fo/skadafragreidingar/

Reports of Severe Accidents to Faroese ships. http://www.dmaib.dk/Sider/Ulykkesrapporter.aspx

Pamphlet about safety on board on langfarðartrolarum. https://www.dropbox.com/s/phlgvn31ssc85yx/Langfarartrolarar.pdf?dl=0

Pamphlet about safety on board on longliners https://www.dropbox.com/s/q757gkacbtixrn8/l\%C3\%ADnuskip\%2C\%2ob\%C3\%B3lkur\%203.pdf?dl=0

Pamphlet about safety on board on trawl boats. https://www.dropbox.com/s/aqy4emldnhwqb5q/Trolarar\%2ob\%(3\%B3lkur\%202.pdf?dl=0

Video about safety on board Fishing ships. https://www.youtube.com/watch?v=8Xd3-xFmpaE. Icelandic Transportation Safety Board. http://www.rns.is/Default.php

156 the report of the Minister of Transport on the work of the seafarer's safety committee. Presented to Alpingi at its 10gth parliamentary session in 1986. https://www.althingi.is/altext/10g/s/pdf/0156.pdf

Law on MSSTC 1991 number 33 19th March http://www.althingi.is/lagas/nuna/1991033.html

Mið and Magn (2016) no. 29.http://fsn.fo/10_MIDogMAGN/Blad_29.pdf

The Danish Maritime Investigation Board: Alvorlige arbejdsulykker i fiskeriet 1999-2013. http://www.dmaib.dk/Sider/Forside.aspx

Announcement no. 620 of 20 th July 1993 about the Danish Fishermen's Occupational Health Council and -Service. Meddelelser fra Søfartsstyrelsen A. Arbejdsmiljø i skibe. Kapitel XII B Arbejdsmiljøråd. https://www.retsinformation.dk/Forms/Ro710.aspx?id=26000

Law no. 457 from May 18th (2011): Lov om sikkerhedsundersøgelse af ulykker til søs. https://www.retsinformation.dk/forms/ro710.aspx?id=137060

Hagstova Føroya. http://www.hagstova.fo/fo/talt-og-hagreitt/fiskiskapur

EU Strategy for the Baltic Sea Region Flagship Project (2014): To lay the groundwork for developing a plan to reduce the number of accidents in fisheries. Baltic Sea Advisory Council Secretariat. www.bsac.dk

Risk assessment tool in Norway. www.fiskrisk.no 


\section{Sammenfatning og konklusion}

Dette projekts tema er ikke tidligere undersøgt i de nordiske lande. Projektet er støttet af Nordisk Ministerråd, og bevillingen har muliggjort realiseringen af nærværende projekt.

\section{Om projektet}

Studiet er baseret på forskningsbaseret viden og dokumentation om udviklingen i arbejdsulykker i de nordiske lande samt på myndigheders og andre instansers redegørelser om initiativer og tiltag for forebyggelse af arbejdsulykker i fiskeriet. Endvidere er der gennemført et fælles nordisk pilotprojekt - en interviewundersøgelse af fiskere i de nordiske lande - med fokus på, hvad de vurderer, der har haft betydning og har virket $\mathrm{i}$ forebyggelsen af arbejdsulykker i fiskeriet.

Projektet er et samarbejde mellem forskningsinstitutioner i Norge, Danmark, Finland, Island og på Færøerne. Sverige er forespurgt, men det var ikke muligt at finde en deltager.

Projektet kunne ikke realiseres uden den velvillige bistand, som vi har modtaget fra de interviewede fiskere, myndigheder, institutioner og andre i de nordiske lande. En stor tak til alle.

I projektet er interessen knyttet til arbejdsulykker i Norden. En arbejdsulykke forstås i denne sammenhæng som en ulykke, der er forekommet i fiskernes arbejde eller i tilknytning til deres arbejdsforhold.

\section{Rapportens indhold}

Rapporten er opdelt i to hovedafsnit: Først præsenteres udviklingen i arbejdsulykker i de respektive lande samt varetagelsen af arbejdsulykker, sikkerhed og iværksatte tiltag i de nordiske lande. Dernæst beskrives og analyseres den gennemførte interviewundersøgelse af fiskere i de nordiske lande, hvor der er fokus på fiskernes vurdering og bedømmelse af virkemidler i den forebyggende arbejdsulykkesindsats. Pilotprojektet, interviewundersøgelse af fiskerne i Norden, omfatter 47 respondenter. Det findes, at de udvalgte fiskere/respondenter på rimelig vis dækker centrale karakteristika ved fisker- 
populationen i de undersøgte lande. Deres udsagn kan dermed anvendes som retningsgivende trends. En større undersøgelse vil naturligvis give et mere valid og sikkert grundlag for konklusion.

Intentionen i konklusionen er at sammenkoble rapportens to dele: Hvad der er gjort og sket kombineret med fiskernes vurdering af, hvad der har virket og haft effekt. På grundlag heraf opstilles anbefalinger til den videre indsats for forbedret sikkerhed i fiskeriet.

\section{Analysen af arbejdsulykker i Norden.}

- Reguleringen af arbejdssikkerhed og sundhed i fiskeriet i Norden følger de internationale organers bestemmelser, hvor især regler og forordninger fra IMO og/eller EU efterleves. I alle nordiske lande har der siden slutningen af 1980erne været øget bevågenhed om sikkerhed i fiskeriet.

- Arbejdsulykker skal anmeldes i alle lande. I rapporten beskrives udviklingen i arbejdsulykker i hvert af de undersøgte lande. Studiet viser, at de nationale opgørelser over anmeldte arbejdsulykker i fiskeriet ikke kan sammenlignes direkte, da basis for de rapporterede arbejdsulykker varierer fra land til land.

- Med projektet foreligger der nu for første gang analyser af udviklingen i fiskeriets arbejdsulykker på Færøerne.

- På basis af de samlede analyser kan trends i udviklingen som valid dokumentation af effekten af interventionen i de nordiske lande præsenteres.

- I danske undersøgelser af anmeldte arbejdsulykker i brancher på land skønnes det, at der er en underrapportering af arbejdsulykker på omkring 40-50\%. I fiskeriet er der utvivlsomt også en betydelig underrapportering. Det viser fx de færøske data om anmeldte arbejdsulykker til det færøske Arbejdstilsyn, hvor der er meget få anmeldelser. Derfor anvendes der i stedet data fra Faroese Accident Insurance Council (FAIC) i den foretagne analyse. I Norden som helhed er omfanget af underrapportering ikke undersøgt, men en undersøgelse ville være nyttig, så udviklingen på området kunne overvåges mere sikkert.

- l et forebyggelsesperspektiv er anmeldelser af arbejdsulykker et relevant instrument. I projektet fremhæves behovet for etablering af en harmoniseret rapportering af arbejdsulykker i nordisk fiskeri, så statistik, data og udviklingen på området kan sammenlignes mere sikkert. 


\section{Fiskeriet, besætningen og sikkerheden}

- Fiskeriets økonomiske betydning i de nordiske lande er stor, især for Færøerne og Island. Antallet af fiskere i flere nordiske lande er cirka halveret de seneste 15 år, men den totale mængde fisk, der fanges, er stort set den samme, eller også er fangsten steget. Fx i Finland er fangsten af fisk steget med $25 \%$.

- Gennemsnitsalderen for fiskerne i de nordiske lande er høj og stigende. Udviklingen peger på, at det er vigtigt at tiltrække nye, yngre personer til sektoren.

- Data fra Danmark viser, at den danske fiskerflådes alder er høj og voksende, og behovet for nybygninger er påtrængende. Mange af de eksisterende fartøjer i Norden er dog fortløbende blevet moderniseret. Informationer fra flere fiskere i interviewundersøgelsen peger på, at forbedret sikkerhed er medtænkt i de nye skibskonstruktioner.

- Antallet af forlis i den nordiske fiskerflåde er faldet bemærkelsesværdigt. Flere forhold spiller ind. Fx i Island peges der på de meget forbedrede vejrrapporteringer til søs. Tiltag for forbedret stabilitet af fartøjerne fx i DK er et andet forhold, der har mindsket forlis. Fartøjernes konstruktion, sikkerhedsudstyret og moderniseringen af fiskerflåden vurderes alt i alt af fiskerne som væsentlig forklaring til faldet i arbejdsulykker.

\section{Arbejdsulykker, sikkerhed og forebyggelse}

- Studiet viser samlet set, at antallet af anmeldte arbejdsulykker sammenholdt med beskæftigede i fiskeriet gennem de seneste mange år er reduceret betydeligt. Det gælder især for alvorlige arbejdsulykker og dødsulykker. Det synes især at være tilfældet i Danmark, Norge og Island, men forekomsten af arbejdsulykker i den nordiske flåde må stadig betragtes som værende for høj.

- I de nordiske lande har der i mange år været et særligt fokus på sikkerhed og forbedrede arbejdsforhold ombord inklusiv forebyggelse af ulykker på små fartøjer, forbedret stabilitet af fartøjerne samt udvikling af sikkerhedsudstyr og flåde. I Danmark har den lovpligtige arbejdspladsvurdering (APV) været et vigtigt instrument i det forebyggende arbejde. I Finland tilbydes en form for arbejdspladsvurdering, inkluderende en sundhedstjeneste, men kun $15 \%$ af fiskerne har valgt at tage imod denne service. 
- Mange arbejdsulykker forekommer på mindre fiskefartøjer. I fx Norge er hovedparten af arbejdsrelaterede dødsfald sket i den kystnære flåde. I flere af landene har opmærksomheden fra myndighedernes side været rettet mod sikkerheden på de mindre fartøjer. Rapportens analyse viser, at opmærksomheden om forebyggelse også bør rettes mod større fartøjer, især trawlere, som den danske analyse finder at være et højrisiko område i relation til rapporterede arbejdsulykker, ikke mindst i forhold til alvorlige arbejdsulykker.

- Danske data viser, at de alvorlige arbejdsulykker i fiskeriet - ikke som forventet forekommer under arbejdsforhold med dårligt vejr, men derimod i rimeligt godt vejr. Forebyggelsespotentialet er dermed større. Danske data over anmeldte arbejdsulykker viser endvidere, at nye eller ny-ansatte fiskere på fartøjet har en betydelig øget risiko for arbejdsulykker sammenlignet med besætningen, der har været længe ombord på skibet. Opmærksomheden herpå har på danske fartøjer bevirket, at oplæring og instruktion af nye besætningsmedlemmer ombord er skærpet på en del fartøjer.

- Interviewundersøgelsen antyder, at arbejdsulykker synes at være en mere almindelig del af færøske fiskeres arbejdsliv, end i de andre lande. Observationen er baseret på forholdsvis få personer. En større repræsentativ undersøgelse er nødvendigt til afklaring.

- Det tekniske sikkerhedsudstyr ved maskiner og det personlige sikkerhedsudstyr ombord i den nordiske fiskerflåde har gennemgået en positiv udvikling, og ifølge fiskerne har det haft stor betydning og bidraget til faldet i arbejdsulykker. Interviewundersøgelsen viser dog også, at der er plads til fortsatte forbedringer.

- Fælles for de nordiske lande er myndighedernes fokusering på regulering, kontrol, information og uddannelse som veje til reducering af antallet af ulykker, og det bedømmes $i$ et forebyggelsesperspektiv generelt positivt af fiskerne.

- I dansk fiskeri har man en bedriftssundhedstjeneste-ordning (BST), Fiskeriets Arbejdsmiljøråd. Det er en instans, der siden slutningen af go'erne har ydet fiskerne mangesidig information og stor praktisk bistand, og som fiskerne værdsætter meget og tilskriver, at faldet i arbejdsulykker er sket. Søfartsstyrelsen i Danmark og Fiskeriets Arbejdsmiljøråd indgår i et tæt samarbejde om forebyggelse af ulykker. Til opfølgning på de rapporterede arbejdsulykker synes de etablerede lokale havnesikkerhedsudvalgene (HSU) at være et system, som har fremmet den målrettede indsats for forebyggelse af arbejdsulykker.

- I Danmark har Fiskeriets Arbejdsmiljøråd udviklet og implementeret et e-baseret Safety Management System. Det er implementeret og anvendes i Danmark, Grønland og Skotland. I Norge anvendes The Norway Compliance Survey Risk 
assessment, FiskRisk, som et tilbud til fiskerne. I Finland er Occupational Health Services (OHS) et tilbud til fiskerne, men tilbuddet når kun ud til et lille mindretal af fiskerne.

- Fiskernes bedømmelse af deres egne faglige organisationers betydning for sikkerhed i fiskeriet var i alle lande meget lav. En anden faktor, som efter fiskernes mening havde haft mindre betydning forebyggelsesmæssigt, var vejledninger, information og lign. fra Søfartsstyrelsen om sikkerhed og forebyggelse i fiskeriet. I Finland forefindes det ikke specifikt i forhold til fiskeri; i de øvrige lande var den typiske begrundelse fra fiskerne, enten at man ikke kendte dem, eller ikke fik det læst.

\section{Sikkerhedskultur}

- Sikkerhedskulturen er ifølge fiskerne øget betydeligt. Sikkerhed og sikkerhedsadfærd tages typisk alvorligt af hele besætningen.

- Alle involverede i samarbejdet - fiskeriinspektør, reder, skibsfører og fiskerne kan skabe gode betingeler for en god sikkerhedskultur og sikkerhedsadfærd.

- Skriftlige materialer, vejledninger og information kan være godt, men vurderes lavt af fiskerne. Direkte dialog med målgruppen synes ifølge fiskerne at have større effekt og fremme det ønskede mål.

- Den bedste forudsætning for høj sikkerhedskultur er, hvor skipperen går forrest og involverer og ansvarliggør besætningen i sikkerhed og sikkerhedsadfærd samt sikrer, at nye ombord vejledes i sikker adfærd. Det fandtes ifølge fiskerne at være udbredt på mange fartøjer.

\section{Uddannelse og sikkerhed}

Uddannelse af fiskere er etableret og udbygget i næsten alle lande i Norden. I Island blev the Maritime Safety and Survival Training Centre etableret i 1985 og formidler sikkerhedskurser for fiskerne. I Norge har sikkerhedsuddannelse været obligatorisk siden 1989 - og lidt senere ligeså i Danmark og på Færøerne (1997). I Finland er uddannelse i sikkerhed obligatorisk for besætningen på de store skibe, men fiskerne i små fartøjer er ikke omfattet.

Uddannelsen i de nordiske lande indeholder sikkerheds- og sundhedsforebyggelse, og i alle lande (undtagen Danmark og Finland) er der et genopfriskningskursus efter 35 år. I Danmark er det et krav, at alle nye fiskere skal gennemgå et sikkerhedskursus, før de kan starte i faget. 
Fiskernes bedømmelse af sikkerhedsuddannelsen viser, at det har været et yderst vigtigt element i forebyggelsen af arbejdsulykker og sikkerhed generelt.

\section{Konklusion og fiskernes bud på bedre sikkerhed}

Samlet set viser undersøgelsen, at den positive udvikling i forekomsten af arbejdsulykker i nordisk fiskeri ikke blot har baggrund i en faktor, men kan tilskrives de integrerede sikkerhedstiltag - en orkestrering af den forebyggende indsats, der har haft positiv og en bemærkelsesværdig effekt på sikkerhedsadfærd og arbejdsulykker i fiskeriet.

Fiskernes bedømmelse af, hvad der har virket og været effektiv i arbejdet for bedre sikkerhed, var mangfoldig og relateret til: Sikkerhedstræning ombord, sikkerhedsuddannelse, sikkerhedsudstyr, skibene og det tekniske udstyr på dækket, hvor sikkerhed er medtænkt og integreret i teknologien, arbejdets tilrettelæggelse og sikring af gode arbejdsrutiner, kommunikationen internt besætningen imellem, adfærd og god sikkerhedskultur og fortløbende samarbejde om risikovurdering af arbejdsopgaver. Endvidere kontrol og inspektioner fra myndigheder baseret på dialog. Interviewene viste også, at der stadig er plads til forbedringer. Det handler om såvel uddannelse, kommunikation og arbejdsmiljøet Der er fortsat en masse tunge løft af fiskekasser og andet grej, hvor flere fiskere pegede på behovet for udvikling af kasseløfter, især i lastrummet. Skibenes stabilitet var et andet tilbagevendende tema om forbedringer. Flere skibe er stadig uden stabiliseringstanke, og fiskernes problemer med bevægeapparatet, især på mindre fartøjer, kræver stadig handling. Træthed og fatigue tonede ligeledes frem som et problem - især blandt fiskerne i Island og på Færøerne. Flere af de ældre skibe er nedslidte, så bedre økonomi i fiskeriet vil være en afgørende vej til bedre sikkerhed generelt set.

\section{Fremtiden}

I ovenstående tekst fremhæves en række temaer, som kan være ledetråde for opfø|gende undersøgelser og som kan anvendes i det videre forebyggende arbejde med sikkerhed og sundhed i fiskeriet.

Fiskeriet har vist, at det er muligt at knække den negative kurve over arbejdsulykker i erhvervet. Udfordringen i fremtiden er, hvordan fastholdes og udvikles den positive udvikling? Hvordan kommunikeres det forebyggende budskab, så involvering og engagement besætningen imellem fastholdes og udvikles? Direkte kommunikation og dialog er effektivt - tilsyneladende mere end vejledninger. Det tyder projektets resul- 
tater på. Hjælp og assistance til fiskerne er også et centralt anliggende. Der kan argumenteres for, at en rådgivende funktion - såsom det danske Fiskeriets Arbejdsmiljøråd - er vigtigt. De øvrige nordiske lande kan utvivlsomt nyde godt af en lignende service.

De foretagne analyser på Færøerne har allerede resulteret i, at der er taget skridt til forandringer. Den konstaterede trend i arbejdsulykkerne blandt de finske fiskere kalder på forandring. Et første skridt kunne være at gøre OHS mere attraktivt og nemt at komme til for de små, selvstændige fiskere, der fisker alene på fjerntliggende steder. Denne målgruppe vil ellers stå uden for de fleste sikkerhedsmæssige initiativer. Regelmæssig og professionelt kompetent samarbejde mellem den enkelte fisker og OHS kunne sandsynligvis forebygge mange helbredsskader og psykiske problemer samt hjælpe fiskeren til at opretholde en god arbejdsevne.

Den Europæiske Fiskerifond har i 2016 ikke afsat midler direkte til forebyggelse af sikkerhed og arbejdsulykker i fiskeriet i de nordiske lande, hvilket er ganske overraskende. Det kan være begrundet i tankegangen, at i fiskeriet går det godt, så det behøves ikke. Det er dog vigtigt ikke at tabe det momentum, som fiskeriet har på ulykkesområdet, så forhåbentligt ændres praksis i fremtiden.

Highlights fra rapporten kan forhåbentligt være til inspiration og anvendelse i landene uden for Norden. Det gælder fx nabolandene i Baltic Sea, hvor seneste rapport ${ }^{8}$ fra Baltic Sea Advisory Council Secretariat (2014) viser, at landene stadig kan lære meget af hinanden for at fremme sikkerhed og mindske arbejdsulykker i fiskeriet.

\footnotetext{
8 reference: EU Strategy for the Baltic Sea Region Flagship Project "To lay the groundwork for developing a plan to reduce the number of accidents in fisheries" Baltic Sea Advisory Council Secretariat April 2014 www.bsac.dk
} 
Nordic Council of Ministers

Ved Stranden 18

DK-1061 Copenhagen K

www.norden.org

\section{Prevention of accidents at work in Nordic fisheries - What has worked?}

The study is based on a combination of previous research and historical initiatives taken by authorities in the respective Nordic countries to promote safety in fisheries. So far there has been limited knowledge about what has worked and has positively influenced the rate and severity of occupational accidents, and fishermen's own experiences with prevention has not been studied. Therefore, the project has been supplemented with a joint Nordic investigation of fishermen, focusing on the accumulation of the fishermen's experience regarding actions that have played a preventive role in terms of occupational accidents in fisheries. On this basis, the results of the study have been summarised. Possible explanations for the significant reduction in the work accidents highlighted by the report, and recommendations for dissemination of the results of the project have been outlined. 